\title{
THE INFLUENCE OF COYOTES ON AN URBAN CANADA GOOSE POPULATION IN THE CHICAGO METROPOLITAN AREA
}

\author{
A Thesis \\ Presented in Partial Fulfillment of the Requirements for \\ the Degree Master of Science in the \\ Graduate School of the Ohio State University
}

By

Justin L. Brown, B.S.

$* * * * *$

The Ohio State University

2007

Master's Examination Committee:

Dr. Stanley D. Gehrt, Advisor

Dr. Robert J. Gates

Dr. David Swanson

Dr. Roger A. Williams

Approved by

Advisor

Graduate Program in Natural Resources 



\begin{abstract}
Canada geese (Branta canadensis) have become common in many urban areas, often creating nuisance problems for human residents. The presence of urban geese has raised concerns about the spread of disease, increased erosion, excessive noise, eutrophication of waterways, and general nuisance problems. Goose populations have grown due to an increase in urbanization resulting in an abundance of high quality food (urban grass) and suitable nesting sites, as well as a decrease in some predators. I monitored nest predation in the Chicago suburbs during the 2004 and 2005 nesting seasons using 3 nest monitoring techniques to identify predators: video cameras, plasticine eggs, and sign from nest using a classification tree analysis. Of 58 nests monitored in 2004 and 286 in 2005, only raccoons (Procyon lotor) and coyotes (Canis latrans) were identified as nest predators. Raccoons were responsible for $22-25 \%$ of depredated nests, but were rarely capable of depredating nests that were actively defended by a goose. Coyotes were responsible for $75-78 \%$ of all Canada goose nest depredation and were documented killing one adult goose and feeding on several others.

The coyote is a top-level predator that had increased in many metropolitan areas in recent years. To determine if coyotes were actively hunting geese or eggs during the nesting season, I analyzed coyote habitat selection between nesting and pre-nesting or post-nesting seasons. Coyote home ranges (95\% Minimum Convex Polygon) were calculated for 19 coyotes to examine third order habitat selection related to goose nest
\end{abstract}


abundance. A $100 \mathrm{~m}$ buffer (buffer habitat) was created and centered on each waterway edge and contained $90 \%$ of all nests. Coyotes showed selection for habitats during all seasons. Buffer habitat was the top ranked habitat in both pre-nesting and nesting seasons, but dropped to third ranked in post-nesting season. Habitat selection across seasons was compared using a repeated measures MANOVA. Habitat selection between pre-nesting and nesting seasons $(P=0.72)$ were similar, while between post-nesting and nesting seasons there was a nearly significant difference $(P=0.07)$. The insignificant change in habitat use across seasons suggests that coyotes did not switch habitat use to take advantage of goose nests. Alternatively, the change in ranking of buffer habitat across seasons suggests that coyotes may have switched habitat use to take advantage of goose nests. The results are not clear as large individual variation between coyotes due to differences in habitat availability, and social status interfere with the results of the analysis.

Even though I failed to find strong support for coyotes actively hunting goose nests, they nevertheless were the primary nest predator in the area and may influence Canada goose populations. To determine the potential influence of coyotes on the Canada goose population, I created a Canada goose matrix population model that included variables such as coyote predation on adults and nests as well as coyote influence on nest desertion. Using the base population model I calculated the Canada goose population to be increasing with $\lambda=1.055$. The removal of all coyote influence on 
the goose population would allow $\lambda$ to increase to 1.214 . Nest predation was the most important factor related to coyotes: the removal of coyote nest predation from the model resulted in a population growth rate $\lambda=1.157$. Modeling results suggest coyotes are serving as a limiting factor for the Canada goose population within the Chicago metropolitan area. 


\section{ACKNOWLEDGMENTS}

I would like to thank my funding sources, the Cook County Animal and Rabies Control and the Max McGraw Wildlife Foundation, for their financial support. I appreciate the opportunity that my advisor Dr. Stan Gehrt gave me to work on such a fascinating project in the Chicago area, and the ideas and support that he provided during my graduate work. The work could not have been completed without the many public and private landholders that voluntarily allowed access to their property. I would like to acknowledge the Cook County Forest Preserve District, Lake County Forest Preserve District, Fermi National Accelerator Laboratory, and the numerous private organizations for providing access to their properties.

I would like to thank the many people that I have worked and spent time with that have made my time as a graduate student very memorable. To my committee members, Dr. Robert Gates, Dr. Roger Williams, and Dr. David Swanson whom I thank for their guidance and statistical support. I am grateful to Dr. Bradley Blackwell for his the support he provided for my population model and to Charles Rizzo and Chris Anchor with the Forest Preserve District of Cook County who assisted with fieldwork and provided knowledge of my study area. To all the graduate students which I worked with while at OSU and spent time with at the Max McGraw Wildlife Foundation which were always willing to help out when needed and have a good time in what little free time we had. I would like to thank Debbie Scott for the time she spent proof reading my chapters. 
My project could not have been completed without the previous work completed by Mikal Cline, Dr. Charles Paine, Dr. John Thompson, Robert Montgomery, Paul Morey and the numerous hard working technicians that have worked on the Canada goose project and the coyote ecology project at the Max McGraw Wildlife Foundation. I would also like to acknowledge my family and friends for their support throughout my life. Lastly, I would like to thank Alison Willingham for her support as my girlfriend, her hard work as my technician, and her presence as a fellow graduate student that was always willing to help out and listen to my ideas no matter how far out they might have been. 
VITA

August 2004 - September 2007 ....... Graduate Research Assistant,
The Ohio State University, Columbus, Ohio
March 2007 - May 2007 ................. Waterfowl Research Technician, The Ohio State
University, Columbus, Ohio

November 2003 - March 2004......... Biological Consultant, Independent Contractor for Pastoria Energy Facility, Tejon, California

January 2003 - March 2004 ............. Field Biologist, Endangered Species Recovery Program (ESRP), Turlock, California

March 2003 - September 2003 ........ Field Researcher, California State University Bakersfield, Biology Department, Bakersfield, California

June 2002 ......................................... B.S. Biology with Minor: Chemistry, California State University Bakersfield, Bakersfield, California

June 2000 - January 2003 ................ Biologist, Mallama Environmental, Bakersfield, California

June 2001- September 2001 ............. Scientific Aid, California Department of Fish and Game, Kernville, California

\section{FIELDS OF STUDY}

Major Field: Natural Resources 
TABLE OF CONTENTS

ABSTRACT

Chapter:

1 IDENTIFICATION OF NEST PREDATORS FOR AN URBAN POPULATION

OF CANADA GEESE …......................................................................... 1

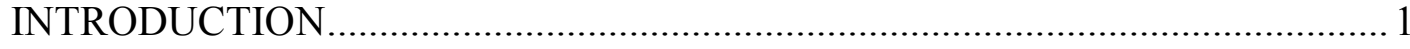

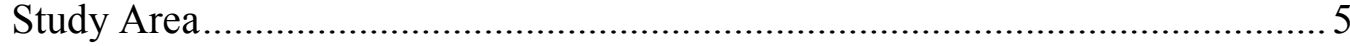

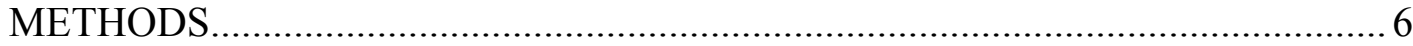

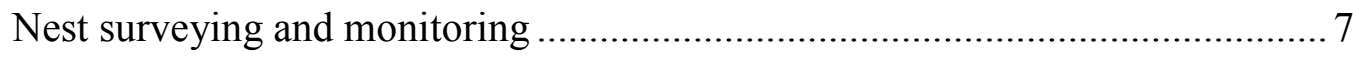

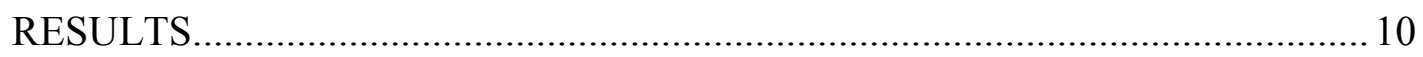

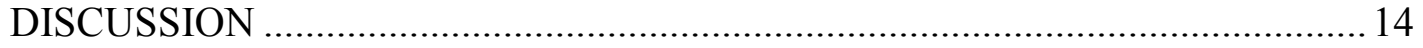

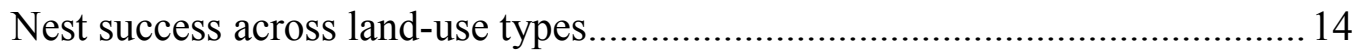

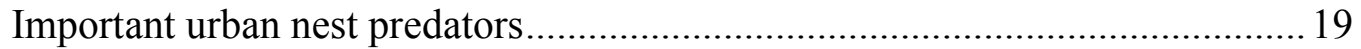

Coyote importance as a nest predator .................................................... 21

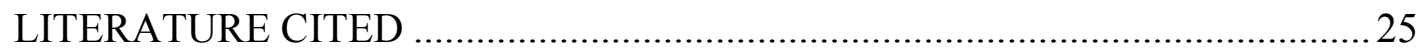

2 COYOTE HABITAT SELECTION RELATIVE TO CANADA GOOSE NESTING

ACTIVITY IN A METROPOLITAN AREA ..................................................... 38

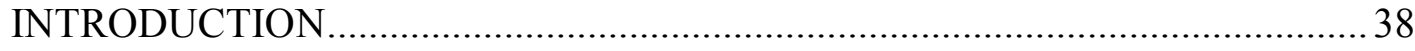

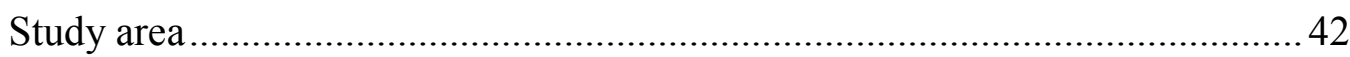

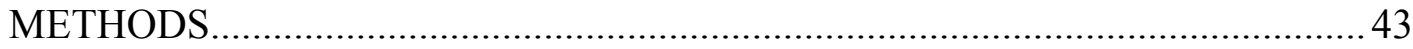

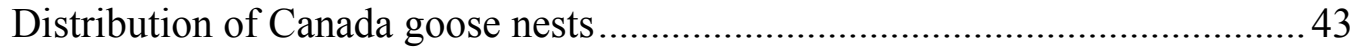

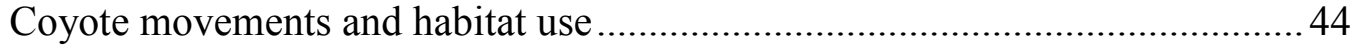

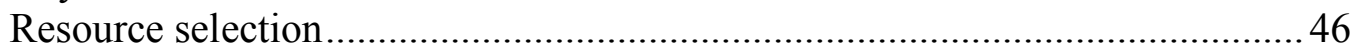

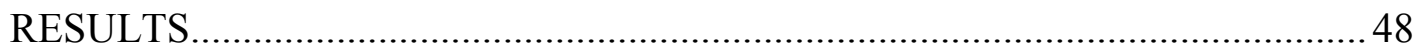

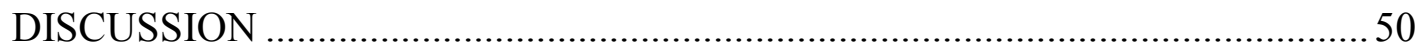

Pre-nesting vs. nesting season habitat selection......................................... 50

Nesting vs. post-nesting season habitat selection..........................................52

Factors influencing coyote habitat selection ............................................... 54

viii 


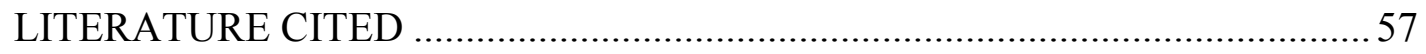

3 INFLUENCE OF URBAN COYOTES ON A RESIDENT CANADA GOOSE

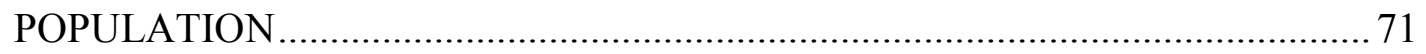

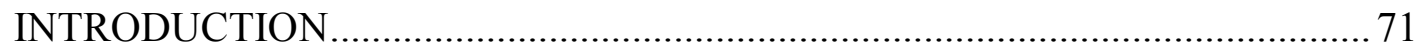

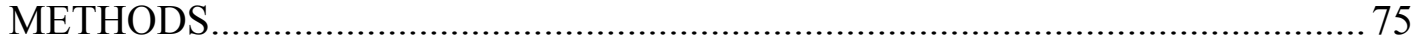

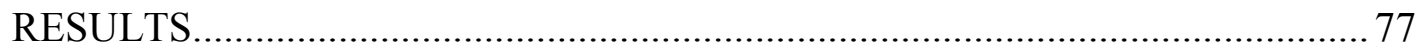

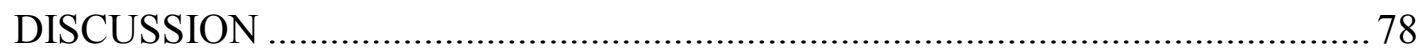

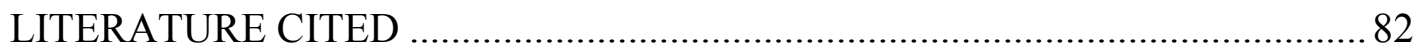

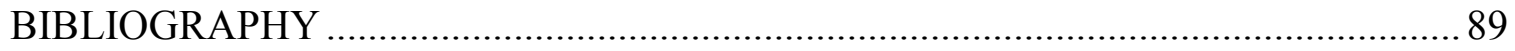

\section{APPENDICES:}

A. QUALITATIVE SIGN COLLECTED FROM DEPREDATED CANADA

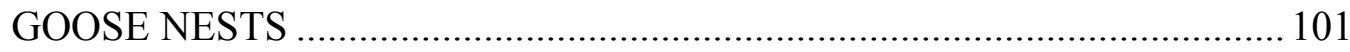

B. QUANTITATIVE SIGN COLLECTED FROM DEPREDATED CANADA

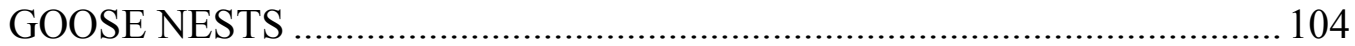

C. MAP RECLASSIFICATION FOR 164 HABITAT AND LANDUSE TYPES.... 107 


\section{LIST OF TABLES}

Table:

1.1 Nest predation information for each fate for Canada goose nests monitored in 2005 using 3 different predator monitoring techniques

2.1 Description of habitat types used to classify nesting habitat and analyze coyote habitat selection in the Chicago metropolitan area. Habitat types were reclassified from Chicago Wilderness Landsat habitat maps

2.2 Simplified ranking matrices for coyotes $(n=12)$ during goose pre-nesting and nesting seasons comparing the number of radio locations for each animal in each habitat type with the proportion of each habitat type within the animal's 95\% MCP home range. Each element in the matrix was replaced by its sign; a triple sign indicates significant deviation from random at $P<=0.05$; a $*$ sign indicates $0.05<P<0.10$.

2.3 Simplified ranking matrices for coyotes $(n=19)$ during goose nesting and postnesting seasons comparing the number of radio locations for each animal in each habitat type with the proportion of each habitat type within the animal's 95\% MCP home range. Each mean element in the matrix was replaced by its sign; a triple sign indicates significant deviation from random at $P<=0.05$; a sign indicates $0.05<P<0.10$.

3.1 Population parameters used to model the resident Canada goose population in

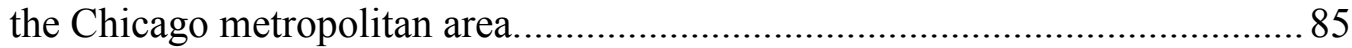

3.2 Elasticity calculations for parameters from the Chicago metropolitan goose population model including coyote influence variables 


\section{LIST OF FIGURES}

Figure:

1.1 Current study area and study area of Cline (2004) and Paine et al. (2003) in the

Chicago metropolitan area. ..................................................................... 33

1.2 Nest success for nests within 3 land-use types during 2005 in the Chicago

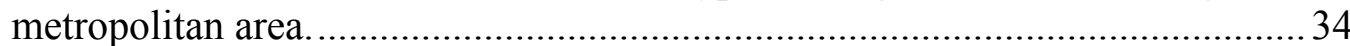

1.3 Classification tree created from sign collected at nests in the Chicago metropolitan area during 2005 and used to identify nest predator for depredated nests from which the predator was unable to identified. The value beneath each terminal node is the predicted class for that node and the number next to each terminal node is the number of learning samples for each class in the node (e.g. Coyote $\mid$ Raccoon). The splitting rule for each intermediate node is next to the node.

1.4 Proportion of depredated nests depredated by coyotes and raccoons (nest predator was identified using sign from nest) within each land use type in the Chicago metropolitan area during the 2005 nesting season.............................36

1.5 Proportion of nests depredated by each nest predator in the Chicago metropolitan area during 2005, identified using 3 different techniques.

2.1 Proportion of Canada goose nests located by Cline (2004) pooled over all years within each habitat type in the Chicago region..................................................6 66

2.2 Number of nests pooled over all years for each fate (depredated and deserted) proportional to the number of active nests during the same time period within the Chicago metropolitan area.

2.3 Coyote use $(n=12)$ and availability of each habitat type during pre-nesting and nesting seasons within the Chicago metropolitan area.

2.4 Coyote use $(n=19)$ and the availability of each habitat type during post-nesting and nesting seasons within the Chicago metropolitan area.

2.5 Monthly coyote habitat use for 6 habitat types starting at the beginning of the nesting season and continuing through the end of the post-nesting season in the Chicago metropolitan area. 
3.1 Population growth rate for the Chicago metropolitan Canada goose population and the estimated population growth rate with coyotes removed from the

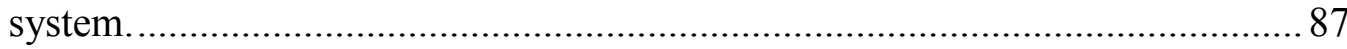

3.2 Population growth rates for the Canada goose population in the Chicago metropolitan area with coyote variables removed and model simulations conducted for each type of coyote influence. 88 


\section{CHAPTER 1}

\section{IDENTIFICATION OF NEST PREDATORS FOR AN URBAN POPULATION OF CANADA GEESE}

\section{INTRODUCTION}

Canada geese (Branta canadensis) have become abundant in many urban environments. Urban geese exhibit higher survival and nest success than rural populations because of the lack of large predators and changes in landscape features which have led to increases in suitable nest sites and an abundance of a high quality food source (urban mowed grass) (Hilley 1976, Ankney 1996, Owen et al. 1998, Smith et al. 1999, Paine et al. 2003). The large population of Canada geese in urban areas has become a nuisance for many urban residents, making it important to examine the effects that urban predator species may have on goose populations.

Conflicts between humans and Canada geese have become increasingly common in cities (Conover 1998, Smith et al. 1999). Homeowners in the Chicago metropolitan area considered Canada geese to cause the greatest problems of all wildlife species (Miller et al. 2001). Geese are attracted to areas with mowed lawns, ponds and few 
visual obstructions, which leads them to concentrate in urban areas increasing goosehuman interactions (Conover and Kania 1991). Large numbers of resident and migrant geese create problems for city parks and golf courses due to heavy grazing and fecal deposition (Conover and Chasko 1985, Smith et al. 1999). Heavy grazing and trampling of plants by Canada geese cause considerable damage resulting in erosion and habitat loss for other species (Smith et al. 1999). Deposition of feces by geese can cause eutrophication of water ways and serve as a disease vector (Conover and Chasko 1985, Kullas et al. 2002). Canada goose eggs in northwestern Germany were found to have antibodies for the influenza A virus (haemagglutinin subtypes H5 and H7), egg drop syndrome, Newcastle disease virus, and duck plague viruses. Canada geese are susceptible to, and possible carriers of, many of these diseases that could infect humans or domesticated fowl (Bonner et al. 2004). Large goose populations increase the possibility of humans contacting potentially harmful bacteria and viruses, making effective control of Canada goose populations an important issue for many cities.

Many methods of controlling the Canada goose population have been evaluated, researching the most efficient, ecologically sound, and publicly accepted way to mitigate the problem. Methods of control fall into 2 categories 1) behavior modification and 2) population control. Behavior modification techniques include chemical hazing (Belant et al. 1996, Belant et al. 1997, Blackwell et al. 1999), mechanical hazing (Heinrich and Craven 1990, Aguilera et al. 1991, Blackwell et al. 2002, Werner and Clark 2006), and habitat manipulation (Conover 1991). Population control methods include 1) reducing reproduction with chemicals (VerCauteren et al. 2003), male sterilization (Converse and Kennelly 1994), destruction of eggs by puncturing holes in eggs shells, addling, or 
causing asphyxiation by oiling (Christens et al. 1995, Smith et al. 1999), 2) culling through hunting (Heusmann 1999), welfare harvest with meat donated to food banks (Smith et al. 1999), or shooting adults at nests (Allan et al. 1995, Coluccy 2001), and 3) translocation of geese from nuisance areas. It is generally recommended that several techniques be used to control nuisance problems caused by Canada geese (Allan et al. 1995, Smith et al. 1999). Cooper and Keefe (1997) found that removal of adult geese, with processing, costs $\$ 24$ per goose while the cost of destroying eggs was $\$ 36$ per egg. Lethal techniques are generally not accepted by the public (Smith et al. 1999), but behavioral techniques only alleviate the nuisance problem for certain areas, pushing geese into adjacent areas. The reduction of hunting opportunities due to urbanization, along with the ineffectiveness of many behavioral techniques and public disagreement with harvest has made it difficult to manage goose populations (Smith et al. 1999, Coluccy et al. 2001).

A natural control of nuisance wildlife species may be emerging in some urban areas as top-level predator numbers increase (Gompper 2002a). Prey populations are influenced through both direct predation and avoidance of useable areas to avoid predation (Brown et al. 1999). Urban predators may provide a broad-scale, natural control of Canada goose populations.

Predators may reduce goose populations, and subsequently relieve goose-human conflicts that occur in many urban areas. Several mammalian predator species which occur in urban landscapes have been documented as nest predators within rural areas. Striped skunks (Mephitis mephitis) are an important waterfowl nest predator (Pasitschniakarts and Messier 1995). Raccoons (Procyon lotor) are an important nest 
predator for many species ranging from Canada geese (Zoellick et al. 2004) to oystercatchers (Sabine et al. 2006), and have been implicated in the decline of bird populations that nest in locations vulnerable to raccoon predation (Schmidt 2003). The opossum (Didelphis marsupialis) is a nest predator (Staller et al. 2005) that is able to survive in highly fragmented landscapes (Tigas et al. 2003), and is common in urban environments. Predation by red foxes (Vulpes vulpes) has been documented as a reason for low nest success among waterfowl in the prairie pothole region (Sargeant 1972, Johnson 1980, Johnson et al. 1989, Sovada et al. 1995). Furthermore, a red fox was documented as a goose nest predator after it was stranded on an island following ice break-up (Klopman 1958).

Coyotes (Canis latrans) have recently become common in many urban-suburban settings (Gibeau 1993, Quinn 1995, Grinder and Krausman 2001, McClennen et al. 2001, Riley et al. 2003, Tigas et al. 2003, Gehrt 2004) and are a capable nest predator of ground nesting birds (Vermeer 1970, Rickard et al. 1982, Staller et al. 2005, Rader et al. 2007). However, the mesopredator release hypothesis predicts that top predators, such as the coyote, may benefit nesting birds by controlling mesopredator populations (Soule et al. 1988, Sovada et al. 1995, Rogers and Caro 1998, Crooks and Soule 1999, Mezquida et al. 2006). The ability of coyotes to thrive in fragmented landscapes makes them an important urban predator (Riley et al. 2003, Tigas et al. 2003). Following the resource dispersion hypothesis (Macdonald 1983), coyotes that utilize highly fragmented landscapes will travel through low quality urban habitat to reach available resources in highly disjunct habitat patches. The use of fragmented habitats will allow coyotes to find nests in highly developed areas during travel between habitat patches. 
Substantial predation of Canada goose nests observed in the Chicago area (Paine et al. 2003, Cline 2004) exemplifies an important development in wildlife community dynamics that may help control urban goose populations. Mitigating nuisance problems associated with Canada geese has been problematic for many areas, as urban goose populations are difficult to manage through behavioral or population control techniques. Managing for certain predators may offer a means of natural population control for Canada geese in urban areas.

Findings from a previous study conducted in the Chicago area by Cline (2004) found that the Canada goose population was experiencing lower nest success and higher nest predation than other Canada goose populations (Fitzner and Rickard 1983, Zoellick et al. 2004). Paine (2003) calculated the annual Canada goose population growth rate and found that the population was increasing at a lower rate than expected. This prompted my study to identify the primary factor controlling the Canada goose population. Due to the low nest success found in the region and the high predation rate, I set my objectives to identify which urban predator was the primary cause for the low nest success of Canada geese in the Chicago metropolitan area.

\section{Study Area}

Field work was focused in the west and northwest Chicago, Illinois, metropolitan area (Figure 1.1). The area includes all or parts of Kane, Cook, Dupage, and Lake Counties and is comprised of urban, suburban, rural, and natural areas, encompassing approximately $1059 \mathrm{~km}^{2}$. These 4 counties are in the top 5 most populated counties in Illinois with 3 of the 5 counties in the top 80 most populated counties in the United States 
(U.S. Census Bureau 2000). Cook County is the second most populated county in the United States with an estimated 5.4 million people. A $1769 \mathrm{~km}^{2}$ area centered on downtown Chicago has undergone a 62\% increase in urban land from 1985-1997 and a loss of $>20,000$ ha of combined natural, undeveloped (but not natural) and agricultural land (Wang and Moskovits 2001).

Elevation of the Chicago region is approximately $200 \mathrm{~m}$ with very little change in topography. Climate in the Chicago metropolitan area is temperate continental (cold winters with warm, humid summers). Temperature and precipitation during winter averaged $-3^{\circ} \mathrm{C}$ and $3.8 \mathrm{~cm} /$ month respectively, whereas summer averaged $19^{\circ} \mathrm{C}$ and 9.9 $\mathrm{cm} / \mathrm{month}$. Fauna in the area included white-tailed deer (Odocoileus virginianus), coyote, opossum, beaver (Castor canadensis), raccoon, red fox, voles (Microtus spp.), white-footed mice (Peromyscus spp.), gray fox (Urocyon cinereoargenteus), skunk, house cat (Felis catus), domestic dog (Canis familiaris).

\section{METHODS}

Study sites were primarily selected from sites with the highest nest predation rate in a previous study (Cline 2004). Additional sites were selected from different land-use types in areas near the high predation sites in order to increase sample size while also observing logistical constraints. Study sites consisted of 3 land use types: natural, commercial, and residential. The natural land use type included private hunting preserves and county forest preserves. Lawn dominated sites were classified as residential land use. Pavement dominated sites were classified as commercial land use. Study sites were delineated by property boundaries or edge of land use type. One residential site with high 
nest success during the previous study (hereafter HNS) was monitored in 2005 to determine if there was any sign of predator activity at sites with low predation.

Nest surveying and monitoring

Sites were surveyed weekly from mid-March to early-June. Nests were marked at nest edge with a small wooden stake placed $4 \mathrm{~cm}$ above ground and marked with a nest identification number. A piece of fluorescent flagging was placed in a tree or shrub $\geq 5$ $m$ from obscure nests. All eggs in each nest were marked with a nest number and egg number. Nest condition, number of eggs, stage of incubation, and number of geese present were recorded. Any nest that was inactive (pair absent from nest) for 2 nest visits and then restarted was counted as a new nest. Any nest restarted after inactive for one nest visit was considered the same nest.

Nest success was calculated for all nests monitored during 2004 and 2005 with known fate. The nest survival model in MARK (White and Burnham 1999) was used to estimate nest success. All nests were pooled to estimate nest success, as 50 of the 58 nests monitored were in the natural land-use type in 2004, with the other 8 nests occurring in the commercial land-use type. Nest success in 2005 was calculated for each of the 3 land-use types. The reliability procedure was used to test for differences in nest success between the 3 nest site types. Any nests with unknown fate were dropped from the analysis.

Nests at all sites were checked every 3 to 5 days to minimize the amount of sign degradation from depredated nests. The number of geese, number of eggs, predator sign, and nest fate were recorded for each nest during each visit. Eggs were checked to make 
sure identification numbers were still present every 9-12 days. If possible this was done without flushing parental geese off the nest. When geese were flushed from a nest the eggs were covered with surrounding down similar to what was seen at nests when geese were absent.

I had 5 Trailmaster 1500 trail cameras (hereafter trail camera) that were used to monitor 8 active nests during the 2004 nesting season. Trail cameras were used at 17 artificial nests, which were located at or near an area that had goose nests in 2004, after the end of the nesting season. Trail cameras were used at artificial nests to see if they influenced what predator was responsible for nest predation events. The detection zone for the trail cameras was situated $1 \mathrm{~m}$ from all nests with the camera view covering the detection zone and edge of nests when possible. The cameras were set to take images in one-minute intervals if the infrared beam was broken.

In addition to the trail cameras used in 2004, one time-lapse (40 hr) infrared (IR) video camera (hereafter video camera) was used to monitor 2 nests at secure sites (where the public was not allowed access). In 2005, 11 video cameras were used to monitor 35 nests at secure sites that had the highest risk of depredation. The video cameras were set to operate from 1800 to 0700 hrs during most of the nesting season, which allowed them to operate for 3 nights without maintenance. Each video camera consisted of a 126 LED IR video camera, Sanyo time-lapse VCR, Pelican waterproof case, deep cycle battery, 2 $\mathrm{m}$ power cord, and $33 \mathrm{~m}$ audio video cable. The video camera lens was placed $\geq 1 \mathrm{~m}$ from the nest with the VCR and battery hidden in vegetation 20-30 m away.

Plasticine eggs were placed in nests at all sites to identify predators through tooth impressions. Plasticine eggs were used in all nests, except at high density sites where 
they were put in half of all nests, until the stock of plasticine eggs was depleted at the beginning of May. Plasticine eggs were placed in nests and secured using 110-176 kg braided fishing line tied on one end to a paper clip molded into the plasticine egg, and on the other end to a $30 \mathrm{~cm}$ metal stake pushed into the middle of each nest. If the plasticine egg was removed from the nest during predation, the area surrounding the nest was searched for remains of the plasticine egg. Plasticine eggs were used to monitor 193 nests at 16 sites in all land-use types. Plasticine eggs were placed in $70 \%$ of nests monitored with video cameras to compare predator identification using either technique.

When a nest was found fully or partially depredated, information pertaining to the condition of the nest site was recorded. This information included: number of eggs remaining in nest, distance of egg shells from the nest, presence or absence of cached eggs, amount of down displaced, and location, number, and size of openings in depredated eggs. Amount of down displaced was categorized into 4 levels $<1 \%, 1-10 \%$, $11-30 \%$ and $>30 \%$.

A classification tree analysis was used to determine what nest depredation sign was most reliable for the identification of nest predators. The classification tree analysis was conducted with the program QUEST (Shih 2003). The learning database for the classification tree was constructed using information from depredated nests where predators were identified using video cameras or plasticine eggs. There were not enough nests where the predator was identified to have both a learning database and a test sample for cross-validation, so a V-fold cross validation technique was conducted in QUEST using 10 folds. To select the most important variables, a statistically unbiased variable selection method was used at the 0.05 significance level. For split point selection, 
discriminant analysis was used as there were only 2 class variables (raccoon and coyote) used in the classification tree (Shih 2003). The standard error was set to 0 to give the smallest cross validation estimate of misclassification error (Shih 2003).

Nesting islands were monitored for predator activity using incandescent flash trail cameras and track stations placed along trails that were near nesting sites. Depredated or abandoned eggs were placed in front of cameras or in track stations to increase the chance to record predator sign. Furthermore, all island edges at nesting sites were searched for predator sign during each nest site visit.

All predator activity and responses of parental geese to the predator were recorded on video. The responses of parental geese were classified as nest defense if they showed any aggressive response toward the predator. Nest defense was considered a new event after 10 minutes had elapsed from the last time the nest was defended from a predator. Predation of a nest was classified as a new predation event only after a diurnal period had passed or after a different predator species took an egg. If the predator could not be identified then it was classified as unknown.

\section{RESULTS}

I monitored 58 nests at 3 different sites in natural and commercial land-use types during 2004. The nest success estimate was $0.161(95 \% \mathrm{CI}=0.080-0.267)$ for nests in 2004. During 2005, 286 nests were monitored at 18 sites in 3 land-use categories. Natural land-use contained the largest number of nests with 168 occurring within 5 sites followed by commercial with 59 nests at 7 sites and residential with 59 nests at 6 sites. Estimated nest success was lower in natural than residential or commercial land-use types 
$\left(X^{2}=44.697, P<0.05\right)$ (Figure 1.2). The residential nest success estimate decreased by $11 \%$ when the HNS site was removed but the difference remained between sites $\left(X^{2}=18.864, P<0.05\right)$. The HNS site had an apparent nest success of $94 \%$ and raccoon sign was the only predator sign found on the island.

Of 17 artificial nests monitored with trail cameras, 10 were depredated. Coyote presence was identified at 4 artificial nests, but only 1 nest was depredated, images from the 3 non depredated nests showed coyotes running away as the camera took the photographs. Trail cameras did not appear to influence raccoons, as all 8 occasions where a raccoon was photographed at an artificial nest resulted in depredation. Raccoons and coyotes were the only predators documented at artificial nests.

Of the 8 active nests monitored with trail cameras, 2 were depredated. A pair of coyotes had 3 images taken of them depredating 1 of the 2 nests. In the second nest depredation event a single raccoon depredated the nest. The camera recorded 2 images of geese defending the nest, 2 images of a raccoon taking eggs with the geese defending the nest, and 2 pictures of the raccoon at the nest without the geese.

The classification tree analysis created a tree with 4 terminal nodes for 2 dependent class variables and a total of 7 nodes (Figure 1.3). The only 2 dependent class variables used were raccoon and coyote, as these were the only predators identified using plasticine eggs or video cameras. The classification tree was used to identify nest predators at 139 nests in all land-use types (Figure 1.4). Coyotes and raccoons were identified as the nest predator for $78 \%$ and $21 \%$ of depredated nests, respectively, and 1 nest predator was unidentifiable. The classification tree identification accuracy was $96 \%$ based on the learning sample and $90 \%$ based on the 10 fold cross-validation. 
Coyotes were the only identified nest predator found to kill nesting geese. No comparison was calculated for egg remains that were whole or with $>25 \%$ of content for nests putatively identified as coyote or raccoon predation as this was an important variable in the classification tree. No cached eggs were found from any nests putatively or positively identified as raccoon predation while $16.5 \%-24 \%$ of eggs from nests depredated by coyotes were found cached (Appendices A and B).

Video cameras were used to monitor a total of 2 nests during 2004 at one site and 35 nests at 6 sites in 2005 (Table 1.1). Nests that were not monitored with cameras were nearly twice as likely to hatch $(0.149,95 \% C I=0.101-0.206, n=155)$ as nests with video cameras $(0.087,95 \% C I=0.030-0.182, n=37)$. Predation rates were similar between nests with and without video cameras $\left(X^{2}=0.830, p=0.362\right)$.

Of the 32 nests that were fully or partially depredated predators were identified in 36 predation events. Coyotes, raccoons, and a combination of coyotes and raccoons were responsible for $75.0 \%, 19.4 \%$, and $5.6 \%$ of predation events, respectively. Geese at nests monitored with video cameras successfully defended 101 times at 13 different nests from coyotes (1\%), mink (2\%), raccoons, $(31 \%)$ and unknown species $(66 \%)$.

Raccoons depredated 2 nests only after a coyote had been seen on the island during the same night as the predation event. Of all nests depredated by raccoons, 53\%$64 \%$ were depredated after coyote sign was found on the island. Coyotes and raccoons were recorded together on 5 different occasions. In 3 of these events the raccoons ran away while in the other 2 events they remained within $7 \mathrm{~m}$ of each other. Coyotes were seen killing a goose at one nest and eating geese in the background at 2 other nests. 
Nests with plasticine eggs had higher nest survival $(0.248,95 \% C I=0.190-0.311$, $n=191)$ than nests without plasticine eggs $(0.136,95 \% C I=0.074-0.218, n=94)$. The depredation rate was similar between nests with plasticine eggs (0.482) and without plasticine eggs (0.495). Desertion was higher in nests with plasticine eggs $(0.167)$ than without plasticine eggs (0.054).

Depredation was the final fate for 92 of the nests monitored with plasticine eggs. Of the 92 nests depredated, I was only able to identify the predator for 26 nests. Coyotes (77\%) were identified using dental impressions as the primary nest predator followed by raccoons (23\%). Fates of plasticine eggs that were not chewed on were either missing $(n=24)$ or left in nest untouched $(n=42)$. In addition, 8 out of 28 plasticine eggs that were left in the nest after nest termination were chewed on by raccoons and 1 was chewed on by an opossum.

No comparison on the accuracy of predator identification using plasticine eggs versus video cameras was calculated as only a single depredation event occurred in which the predator was documented on video leaving dentition on a plasticine egg. Predation rates of coyotes and raccoons were similar using plasticine eggs, video cameras and sign from nests $\left(X^{2}=0.226, P=0.893\right)$ (Figure 1.5). Video cameras were more successful at identifying predation events than plasticine eggs $\left(X^{2}=14.2, P<0.001\right)$.

Nest desertion occurred at 42 nests with 37 of them occurring in 2005. During 2004 predator sign was only searched for if a nest had been depredated. During 2005 all nesting sites were searched for predator sign during each nest site visit. Coyote sign was found within the last 2 nest visits for $73 \%$ of all nests deserted in 2005 . 


\section{DISCUSSION}

Nest success across land-use types

Differences in nest success between land-use types can be important for managing Canada goose populations. Nests in natural land-use areas had the lowest nest success, which was expected because coyotes use natural habitats more than developed habitats (Quinn 1997a, Morey 2004, Atwood 2006). Decreased predator presence and decreased fighting among nesting geese at residential and commercial sites, because of the reduced nesting densities in these land-use types, has likely led to lower probabilities of depredation and desertion, resulting in higher nest success. Lower predator presence at commercial sites leading to higher nest success is supported by other studies that found the reduction in natural or undeveloped habitats in highly fragmented urban areas reduced coyote use (Grinder and Krausman 2001, Crooks 2002, Riley et al. 2003, Morey 2004). Residential sites were highly fragmented and composed primarily of apartment and condominium complexes that were lawn-dominated with ponds. These sites also appeared to have high amounts of human activity during nocturnal periods, which may further reduce the use of these sites by coyotes (Grinder and Krausman 2001, Way et al. 2004). The observed decrease in desertion at most sites in these 2 land-use types is most likely explained by an increase in the distance between nests resulting in a reduction of interspecific strife and lower presence of coyotes in these highly developed areas, making nest desertion less of a factor for nests in these highly urban habitats.

Due to the philopatric nature of geese (Hanson 1965), successful goose nesting sites can become overpopulated, particularly in areas of high nest success. Conflicts 
between geese and humans will increase as the goose population grows in areas of high nest success. However, goose human conflicts may be alleviated as coyotes find ways to survive in highly developed areas (Gibeau 1993, Grinder and Krausman 2001, Riley et al. 2003, Gehrt 2004). The high abundance of geese in some high nest success sites may cause them to become an important food source for coyotes as they find ways to exist in many areas where they previously did not occur.

Nest predator identification techniques

One of the most studied aspects of avian ecology has been nest success and the identification of nest predators. Several techniques have been used to identify nest predators such as using sign from depredated nests (Sargeant et al. 1998, Anthony et al. 2004, Zoellick et al. 2004, Staller et al. 2005), hair snares (Pasitschniakarts and Messier 1995), plasticine eggs (Pasitschniakarts and Messier 1995, Anthony et al. 2006), still cameras (DeVault et al. 2005, Anthony et al. 2006), and video cameras (Pietz and Granfors 2000, Thompson and Burhans 2004). Video cameras have been the mostly widely accepted technique to identify nest predators (Thompson et al. 1999, Pietz and Granfors 2000, Staller et al. 2005). Many techniques typically need to be applied in order to increase sample sizes and accurately estimate nest predator importance. I used 4 techniques to identify nest predators including still cameras, analyzing sign from nests, plasticine eggs, and video cameras, each of which had advantages and disadvantages for monitoring goose nests.

The trail cameras used in 2004 were not used during 2005 due to an apparent bias in predator response to the cameras. Raccoons were attracted to the cameras whereas coyotes avoided cameras and nests associated with them. Coyotes appeared to be scared 
from the camera when the flash went off as they walked towards the nest. In addition to running from the nest once the camera flash went off, the cameras presence may have kept certain coyotes away, many coyotes were likely scarred from the area when other species would set the camera off (Sequin et al. 2003). Contrary to coyotes, raccoons appeared to be attracted to the trail cameras and were often photographed sitting in the detection area while consecutive pictures were taken. Trail cameras did not negatively affect raccoons as all of the artificial nests at which they were photographed were depredated.

The use of video cameras allowed the actual or attempted predation events to be viewed, which permitted the accurate identification of nest predators. The disadvantages of using video cameras included the initial expense, large requirement of man hours to keep video cameras operating, and the viewing of video tapes. Furthermore, video cameras are unnatural items that can influence predators and affect which predators will approach the nest. Some species may be attracted, whereas other wary species may be dissuaded from depredating the nest. Sequin et al (2003) found that coyotes were rarely caught on film and avoided areas with cameras, which they explained as coyotes avoiding areas that are associated with people. I do not believe that this is an important factor in my study, which took place in an urban setting, making it infeasible for coyotes to constantly avoid items associated with human presence. During the study raccoons did not appear to be wary of the video cameras, but instead seemed to be attracted as they frequently approached and touched the cameras. Urban and suburban raccoons have been shown to feed on anthropogenic resources (Prange et al. 2004) and thus may associate new objects as potential food sources. The cameras did not appear to have a 
large affect on predation as each identification technique showed similar predation rates for each respective predator. If the cameras would have had an effect on nest predation I would have expected one of 2 outcomes, 1) nests with cameras would have higher nest success than nests without cameras or 2) raccoons would have been the primary nest predator. The lower success of nests with cameras was expected because cameras were placed at nests in sites with the highest predation rates during the previous study, or at nests sites that were experiencing high predation during that season.

Plasticine eggs have rarely been used in active nests because they are often destroyed as temperature increases during incubation. I avoided the destruction of the egg during incubation by filling a blown domestic egg with plasticine, thereby allowing predators to be identified at active nests (Anthony et al. 2006). Advantages of using plasticine eggs were the low expense and the ability to use them in unsecured locations. During the study, video cameras could not be used at commercial areas or many residential sites due to the risk of theft or damage as well as the lack of suitable hiding places. A disadvantage of using plasticine eggs is that the correct predator may not always be identified. This typically occurs when the nest is depredated by one species, but the plasticine egg has dentition from a different predator (Thompson and Burhans 2004). This occurred in the current study in a few circumstances, as the plasticine egg was left in 28 different nests after the nest was terminated, and of these 28 nests 8 had dentition from a predator by the second visit after termination of the nest. This was not likely a large problem as nests were checked every 3 to 7 days reducing the likelihood of another predator leaving dentition in the plasticine egg. Furthermore, the predation rate 
for each respective predator was similar for all 3 nest monitoring techniques, suggesting this was not an important problem during this study.

Using sign from nests to create a classification tree was an efficient way to identify predators over a large area with little equipment expense (Staller et al. 2005). Other predator identification techniques were used with the classification tree analysis, as sign from nests in which the predator was positively identified was used as learning data to build the classification tree (Breiman et al. 1984). One difficulty associated with this technique is that one item of sign can confound the analysis, leading to an inaccurate prediction of the predator. In this study, misidentification likely occurred at one of the residential sites where coyote sign was never documented yet 6 nests were identified as having been depredated by a coyote. This identification was likely confounded by the low number of egg shells recovered at this site, which was covered in thick vegetation and refuse, making it difficult to find egg remains. This may have also been a problem at commercial and residential sites where maintenance crews may have removed egg remains. At one commercial site no sign of egg remains were found around the nest, but depredated eggs were discovered approximately $300 \mathrm{~m}$ away.

In order for a predator to be used in the classification tree analysis, sign must be collected at several nests where that predator was positively identified as the nest predator (Breiman et al. 1984). This condition is not likely to eliminate predator species that are responsible for depredating large numbers of nests, but may exclude some species that are difficult to positively identify. For instance, it is likely that predators other than raccoons or coyotes depredated a few nests, as fox tracks were observed on 1 island, but foxes were never recorded as a predator using plasticine eggs or video 
cameras. Other predators such as mink may have depredated a few nests, which were captured on video getting fended away as they attempted to get to a goose nest. Most urban species such as foxes or smaller predators are not likely to be important factors in goose nest depredation as geese are able to defend their nests from these predators (Bety and Gauthier 2001). The number of nests where the predator was positively identified needs to be higher for studies where more predator species were identified. For example, the minimum number of nests depredated by raccoons with sign collected that could be used in the classification tree analysis was 10 nests, but this is largely dependent on overlap in sign characteristics from each nest predator.

Important urban nest predators

Mammals were the only predator group that was found to depredate goose nests. On a single occasion a gull was observed feeding on a marked abandoned egg, but this was the only event of avian egg scavenging seen during this study. Raccoons were the most abundant predator species in the Chicago area (Prange and Gehrt 2004, Gehrt and Prange 2007). Because of the high densities raccoon populations can occur in as well as serving as a primary predator of goose nests in previous studies (Zoellick et al. 2004) raccoons were assumed to be an important nest predator of Canada geese. Many birds that are not large enough to defend their nests and nest in locations vulnerable to raccoons are susceptible to raccoon nest predation (Schmidt 2003). Goose nests are typically in ideal locations for raccoons to be the primary predator as they are ground nesters with preferred nesting sites on islands or areas near bodies of water (Hanson 1965, Cline 2004, Zoellick et al. 2004). However, the large size and aggressive nature of 
Canada geese allow them to fend raccoons from their nest, thus making raccoons unable to depredate large numbers of nests. The number of times that raccoons were fended away from nests by geese on video was modest, because many of the instances where the predator was unknown were believed to have been raccoons that did not get close enough to the nest to be identified. Despite high densities in these urban areas raccoons were a secondary predator and were not likely to play an important role on the goose population, primarily due to their inability to flush geese from their nests. Even as the secondary predator, raccoons were able to depredate several nests while geese were away from the nest feeding or resting.

Raccoons and coyotes thrive in shared areas and interact in important ways (Gehrt and Prange 2007). The presence of coyotes allowed raccoons to access nests that they would likely have been fended from (Bety and Gauthier 2001). As coyotes arrived at a nest site geese would leave, thereby allowing raccoons to exploit the opportunity to depredate eggs. The presence of coyotes may influence the number of nests that raccoons are able to depredate as coyote sign (images on camera, tracks, scat or bite marks) was found at the nest site for $73 \%$ of nests that were depredated by raccoons. This idea is supported further when the HNS site is examined. Raccoons were the only predator present at this site, which had high nest success and very little predation (3 partial predations, 2 full predations, out of 35 nests). Raccoon sign was found at this site during every visit so it is likely that attempts to depredate eggs were usually thwarted by the parental geese. There were only 2 occasions during this study when raccoons were able to successfully depredate nests while an adult goose was present. A single occurrence was documented using a video camera after a coyote had depredated several 
nests on the island over the previous week. The raccoon ran at the monitored nest and the incubating goose flushed, allowing it to depredate the nest. During the second event, which was recorded using a trail camera, a raccoon appeared to fend off the parental geese as it took eggs out of the nest.

Coyote importance as a nest predator

Coyote numbers have appeared to increase dramatically in the Chicago region since the early 1990's. The number of coyotes handled by wildlife control operators in the Chicago region between 1991 and 1999 has shown a 1,188\% increase (Gehrt 2004). In addition to conflicts with people, coyotes are an important predator in the urban setting.

All nest monitoring techniques identified coyotes as the primary nest predator. Coyotes likely depredated an even larger number of nests than were documented as at 1 site coyotes were recorded taking eggs out of 2 different nests the same night that the eggs were laid and no eggs were found in either nest bowl during any nest site visit. I believe this pattern occurred on many more occasions, as nest bowls were found at many sites that did not have any down or geese defending them. Under these circumstances, the predation rate will be underestimated, as will the magnitude of the effect that coyotes have on the urban goose population.

This is the first time coyotes have been documented as an important goose nest predator in an urban environment, but have previously been documented in rural areas (Vermeer 1970, Fitzner and Rickard 1983). Studies conducted along the Hanford Reach of the Columbia River and in southeastern Alberta documented a reduction in nest 
success with the presence of coyotes on islands with nesting geese (Vermeer 1970, Hanson and Eberhardt 1971, Fitzner and Rickard 1983). Heavy predation on certain islands caused the nesting population to be reduced from a mean of 215 nests per year from 1953-1971 to 135 nests per year from 1971-1981 (Hanson and Eberhardt 1971, Fitzner and Rickard 1983). Hanson and Eberhardt (1971) recorded a 70\% nest success over a 17 year period, but only documented significant coyote predation during 4 years of the 17 year study. Of the 18 monitored islands 1 contained $33 \%$ of all nests and saw high predation during the last several years of the study, which caused nest numbers to decrease on the island from a high of a 129 nests in 1957 to 3 nests in 1970 . Since 1970 coyotes had established consistent residence on the island and geese had largely avoided nesting on the island (Fitzner and Rickard 1983). In southeastern Alberta, Vermeer (1970) found that an island with coyotes present had a hatching success for Canada geese that was only $33 \%$ that of an island with no coyotes present. These studies support my findings which show that high coyote predation rates result in lower nest success, which ultimately leads to a reduction in the number of nesting geese at these sites.

Several of my study sites contained islands with very little nesting activity, which was likely due to predator use of these islands. One site encompassed 7 islands of which only one supported a large aggregation of nests ( $>50$ nests) and although several of the remaining islands consisted of 2-3 times the area, each island had less than 6 nests. The difference in the number of nests is likely explained by distance to shore, with increased distance resulting in reduced accessibility to predators (Cline 2004, Zoellick et al. 2004). These results demonstrate the important effect that coyotes can have on goose 
populations and the reduction in goose numbers that could occur with the presence of coyotes.

Coyotes can have a large impact on even large aggregations of nests as they have the ability to consume or store large numbers of eggs. The ability to store and consume eggs gives coyotes the ability to potentially reduce nesting success over a large area. Penned coyotes have been shown to consume 132 chicken eggs over a $72 \mathrm{hr}$ period as well as cache several more (Sooter 1946). One of my study sites consisted of 5 islands, of which nests were monitored on 2 of them. More than 180 eggs were depredated from 43 nests on the 2 islands. Occasional nest checks on the remaining 3 islands revealed that all of the nests on those islands were also depredated.

Because coyotes can travel over fragmented landscapes and use disjunct habitat patches, coyotes are likely able to depredate goose nests in all land-use types of the urban landscape (Grinder and Krausman 2001, Riley et al. 2003, Morey 2004). Following the resource dispersion hypothesis (Macdonald 1983), as fragmentation of an area increases, coyote home ranges must increase in order to incorporate enough habitat patches to meet their basic needs. Certain locations in fragmented areas may experience higher coyote predation in the future as coyotes find nesting sites as they move through developed areas to access natural habitat patches. The ability of coyotes to find nests in highly developed areas is supported by the high proportion of depredated nests that were identified as coyote predation in the commercial land-use type. This ability to use highly fragmented landscapes has allowed coyotes to become the primary predator of Canada goose nests in all landscapes in the Chicago area. 
Coyotes may not only be responsible for low nest success via predation, but may also cause nests to fail through desertion. The high percentage of nests that were deserted when coyotes were present at the nest site and the lack of nest desertion at the HNS site indicate coyotes may have been the primary cause for most nest desertions. The presence of coyotes at nest sites may cause geese to abandon their nests as coyotes are capable of killing nesting geese.

In summary, 4 nest predator identification techniques were used including plasticine eggs, video cameras, and analyzing sign from nest. All methods used in 2005, gave similar results with predator identification varying by less than $3 \%$. The trail cameras used in 2004, biased predation rates as the flash from the camera scared coyotes away and potentially attracted raccoons. Raccoons and coyotes were the only predators identified depredating goose nests. Coyotes were identified as the primary predator and were responsible for greater than $75 \%$ of depredated nests. Results from this study strongly implicate coyotes as the primary predator of Canada goose nests, and occasionally adult geese, within the Chicago region, and provide an example of the direct top-down effect coyotes have on a prey species in an urban landscape. 


\section{LITERATURE CITED}

Aguilera, E., R. L. Knight, and J. L. Cummings. 1991. An evaluation of two hazing methods for urban Canada geese. Wildlife Society Bulletin 19:32-35.

Allan, J., J. Kirby, and C. Feare. 1995. The biology of Canada geese Branta canadensis in relation to the management of feral populations. Wildlife Biology 1:129-143.

Ankney, C. D. 1996. An embarrassment of riches: Too many geese. Journal of Wildlife Management 60:217-223.

Anthony, R. M., J. B. Grand, T. F. Fondell, and B. F. J. Manly. 2004. A quantitative approach to identifying predators from nest remains. Journal of Field Ornithology 75:40-48.

Anthony, R. M., J. B. Grand, T. F. Fondell, and D. A. Miller. 2006. Techniques for identifying predators of goose nests. Wildlife Biology 12:249-256.

Atwood, T. C. 2006. The influence of habitat patch attributes on coyote group size and interaction in a fragmented landscape. Canadian Journal of Zoology 84:80-87.

Belant, J. L., T. W. Seamans, L. A. Tyson, and S. K. Ickes. 1996. Repellency of methyl anthranilate to pre-exposed and naive Canada geese. Journal of Wildlife Management 60:923-928.

Belant, J. L., L. A. Tyson, T. W. Seamans, and S. K. Ickes. 1997. Evaluation of lime as an avian feeding repellent. Journal of Wildlife Management 61:917-924.

Bety, J., and G. Gauthier. 2001. Effects of nest visits on predator activity and predation rate in a Greater Snow Goose colony. Journal of Field Ornithology 72:573-586.

Blackwell, B. F., G. E. Bernhardt, and R. A. Dolbeer. 2002. Lasers as nonlethal avian repellents. Journal of Wildlife Management 66:250-258.

Blackwell, B. F., T. W. Seamans, and R. A. Dolbeer. 1999. Plant growth regulator (Stronghold (TM)) enhances repellency of anthraquinone formulation (Flight Conirol (TM)) to Canada geese. Journal of Wildlife Management 63:1336-1343.

Bonner, B. M., W. Lutz, S. Jager, T. Redman, B. Reinhardt, U. Reichel, V. Krajewski, R. Weiss, J. Wissing, W. Knickmeier, W. H. Gerlich, U. C. Wend, and E. F. Kaleta. 2004. Do Canada geese (Branta canadensis Linnaeus, 1758) carry infectious agents for birds and man. European Journal of Wildlife Research 50:78-84.

Breiman, L., J. H. Friedman, R. A. Olshen, and C. J. Stone. 1984. Classification and regression trees. Chapman and Hall, New York, NY. 
Brown, J. S., J. W. Laundre, and M. Gurung. 1999. The ecology of fear: Optimal foraging, game theory, and trophic interactions. Journal of Mammalogy 80:385399.

Christens, E., H. Blokpoel, G. Rason, and S. W. D. Jarvie. 1995. Spraying white mineraloil on Canada goose eggs to prevent hatching. Wildlife Society Bulletin 23:228230 .

Cline, M. 2004. Productivity of giant Canada geese (Branta canadensis maxima) in northeasten Illinois. Masters Thesis. Southern Illinois University of Carbondale, Carbondale.

Coluccy, J. M. 2001. Reproductive ecology, bioenergetics, and experimental removals of local giant Canada geese (Branta canadensis maxima) in central Missouri. Ph.D. University of Missouri, Columbia.

Coluccy, J. M., R. D. Drobney, D. A. Graber, S. L. Sheriff, and D. J. Witter. 2001. Attitudes of central Missouri residents toward local giant Canada geese and management alternatives. Wildlife Society Bulletin 29:116-123.

Conover, M. 1998. Reproductive biology of an urban population of Canada geese. Pages 67-70 in D. H. Rusch, M. D. Samuel., D. D. Humburg, and B. D. Sullivan, editors. Proceedings of the 1998 International Canada Goose Symposium, Milwaukee Wi.

Conover, M. R. 1991. Herbivory by Canada geese - diet selection and effect on lawns. Ecological Applications 1:231-236.

Conover, M. R., and G. G. Chasko. 1985. Nuisance Canada goose problems in the eastern United States. Wildlife Society Bulletin 13:228-233.

Conover, M. R., and G. S. Kania. 1991. Characteristics of feeding sites used by urbansuburban flocks of Canada geese in Connecticut. Wildlife Society Bulletin 19:3638 .

Converse, K. A., and J. J. Kennelly. 1994. Evaluation of Canada goose sterilization for population-control. Wildlife Society Bulletin 22:265-269.

Cooper, J., and T. Keefe. 1997. Urban Canada goose management: policies and procedures. Transactions of the North American Wildlife and Natural Resources Conference 62:412-430.

Crooks, K. R. 2002. Relative sensitivities of mammalian carnivores to habitat fragmentation. Conservation Biology 16:488-502.

Crooks, K. R., and M. E. Soule. 1999. Mesopredator release and avifaunal extinctions in a fragmented system. Nature 400:563-566. 
DeVault, T. L., M. B. Douglas, J. S. Castrale, C. E. Mills, T. Hayes, and O. E. Rhodes. 2005. Identification of nest predators at a least tern colony in southwestern Indiana. Waterbirds 28:445-449.

Fitzner, R. E., and W. H. Rickard. 1983. Canada goose nesting performance along the Hanford reach of the Columbia River, 1971-1981. Northwest Science 57:267-272.

Gehrt, S. D. 2004. Ecology and management of striped skunks, raccoons, and coyotes in urban landscapes. Pages 81-104 in N. Fascione, A. Delach, and M. E. Smith, editors. People and Predators: from conflict to coexistence. Island Press, Washington DC.

Gehrt, S. D., and S. Prange. 2007. Interference competition between coyotes and raccoons: A test of the mesopredator release hypothesis. Behavioral Ecology 18:204-214.

Gibeau, M. 1993. Use of urban habitats by coyotes in the vicinity of Banff, Alberta. Masters Thesis. University of Montana.

Gompper, M. E. 2002a. Top carnivores in the suburbs? Ecological and conservation issues raised by colonization of northeastern North America by coyotes. Bioscience 52:185-190.

Grinder, M. I., and P. R. Krausman. 2001. Home range, habitat use, and nocturnal activity of coyotes in an urban environment. Journal of Wildlife Management 65:887-898.

Hanson, H. C. 1965. The giant Canada goose. Carbondale: Southern Illinois University Publisher.

Hanson, W. C., and L. L. Eberhardt. 1971. A Columbia River Canada goose population, 1950-1970. Wildlife Monographs 28:1-56.

Heinrich, J. W., and S. R. Craven. 1990. Evaluation of 3 damage abatement techniques for Canada geese. Wildlife Society Bulletin 18:405-410.

Heusmann, H. W. 1999. Special hunting seasons and resident Canada goose populations. Wildlife Society Bulletin 27:456-464.

Hilley, J. D. 1976. Productivity of a resident giant Canada goose flock in northeastern South Dakota. Masters Thesis. South Dakota State University.

Johnson, D. H. 1980. The comparison of usage and availability measurements for evaluating resource preference. Ecology 61:65-71. 
Johnson, D. H., A. B. Sargeant, and R. J. Greenwood. 1989. Importance of individual species of predators in nesting success of ducks in the Canadian Prairie Pothole Region. Canadian Journal of Zoology 67:291-297.

Klopman, R. K. 1958. The nesting of the Canada goose at Dog Lake, Manitoba. Wilson Bulletin 70:168-183.

Kullas, H., M. Coles, J. Rhyan, and L. Clark. 2002. Prevalence of Escherichia coli serogroups and human virulence in faeces of urban Canada geese (Branta canadensis). International Journal of Environmental Health Research 12:153-162.

Macdonald, D. W. 1983. The ecology of carnivore social-behavior. Nature 301:379-384.

McClennen, N., R. R. Wigglesworth, and S. H. Anderson. 2001. The effect of suburban and agricultural development on the activity patterns of coyotes (Canis latrans). American Midland Naturalist 146:27-36.

Mezquida, E. T., S. J. Slater, and C. W. Benkman. 2006. Sage-Grouse and indirect interactions: Potential implications of coyote control on Sage-Grouse populations. Condor 108:747-759.

Miller, C. A., L. K. Campbell, and J. A. Yeagle. 2001. Attitudes of homeowners in the greater Chicago metropolitan region toward nuisance wildlife. SR-00-02, Illinois Natural History Survey, Champaign, IL.

Morey, P. 2004. Landscape use and diet of coyotes, Canis latrans, in the Chicago metropolitan area. Masters Thesis. Utah State University, Logan.

Owen, M., J. Kirby, and D. Salmon. 1998. Canada geese in Great Britain: History, problems, and prospects. Pages 497-505 in D. H. Rusch, M. D. Samuel., D. D. Humburg, and B. D. Sullivan, editors. Proceedings International Goose Symposium, Milwaukee Wi.

Paine, C. R., J. D. Thompson, R. Montgomery, M. Cline, and B. D. Dugger. 2003. Status and management of Canada geese in northeastern Illinois. Final report W-131-R1 to R3, Illinois Department of Natural Resources.

Pasitschniakarts, M., and F. Messier. 1995. Predator Identification at simulated waterfowl nests using inconspicuous hair catchers and wax-filled eggs. Canadian Journal of Zoology 73:984-990.

Pietz, P. J., and D. A. Granfors. 2000. Identifying predators and fates of grassland passerine nests using miniature video cameras. Journal of Wildlife Management 64:71-87.

Prange, S., and S. D. Gehrt. 2004. Changes in mesopredator-community structure in response to urbanization. Canadian Journal of Zoology 82:1804-1817. 
Prange, S., S. D. Gehrt, and E. P. Wiggers. 2004. Influences of anthropogenic resources on raccoon (Procyon lotor) movements and spatial distribution. Journal of Mammalogy 85:483-490.

Quinn, T. 1995. Using public sighting information to investigate coyote use of urban habitat. Journal of Wildlife Management 59:238-245.

Quinn, T. 1997a. Coyote (Canis latrans) food habits in three urban habitat types of western Washington. Northwest Science 71:1-5.

Rader, M. J., T. W. Teinert, L. A. Brennan, F. Hernandez, N. J. Silvy, and X. B. Wu. 2007. Identifying predators and nest fates of bobwhites in southern Texas. Journal of Wildlife Management 71:1626-1630.

Rickard, W. H., W. C. Hanson, and R. E. Fitzner. 1982. The non-fisheries biological resources of the Hanford reach of the Columbia River. Northwest Science 56:6276.

Riley, S. P. D., R. M. Sauvajot, T. K. Fuller, E. C. York, D. A. Kamradt, C. Bromley, and R. K. Wayne. 2003. Effects of urbanization and habitat fragmentation on bobcats and coyotes in southern California. Conservation Biology 17:566-576.

Rogers, C. M., and M. J. Caro. 1998. Song sparrows, top carnivores and nest predation: A test of the mesopredator release hypothesis. Oecologia (Berlin) 116:227-233.

Sabine, J. B., S. H. Schweitzer, and J. M. Meyers. 2006. Nest fate and productivity of American oystercatchers, Cumberland Island National Seashore, Georgia. Waterbirds 29:308-314.

Sargeant, A. B. 1972. Red fox spatial characteristics in relation to waterfowl predation. Journal of Wildlife Management 36:225-236.

Sargeant, A. B., M. A. Sovada, and R. J. Greenwood. 1998. Interpreting evidence of depredations of duck nests in the praitie pothole region. in. U.S. Geological Survey, Northern Prairie Wildlife Research Center, Jamestown, ND and Ducks Unlimited, Inc., Memphis TN. Jamestown, ND: Northern Prarie Wildlife Research Center Online. http://www.npwrc.usgs.gov/resource/birds/depred/depred.htm (version 02JUL99).

Schmidt, K. A. 2003. Nest predation and population declines in Illinois songbirds: A case for mesopredator effects. Conservation Biology 17:1141-1150.

Sequin, E. S., M. M. Jaeger, P. F. Brussard, and R. H. Barrett. 2003. Wariness of coyotes to camera traps relative to social status and territory boundaries. Canadian Journal of Zoology 81:2015-2025. 
Shih, Y. S. 2003. Quest User Manual. Department of Mathematics National Chung Cheng University, Taiwan.

Smith, A. E., S. R. Craven, and P. D. Curtis. 1999. Managing Canada geese in urban environments. in Jack Berryman Institute Publication 16, and Cornell University Cooperative Extension, Ithaca, NY.

Sooter, C. A. 1946. Habits of coyotes in destroying nests and eggs of waterfowl. Journal of Wildlife Management 10:33-38.

Soule, M. E., D. T. Bolger, A. C. Alberts, J. Wright, M. Sorice, and S. Hill. 1988. Reconstructed dynamics of rapid extinctions of chaparral-requiring birds in urban habitat islands. Conservation Biology 2:75-92.

Sovada, M. A., A. B. Sargeant, and J. W. Grier. 1995. Differential effects of coyotes and red foxes on duck nest success. Journal of Wildlife Management 59:1-9.

Staller, E. L., W. E. Palmer, J. P. Carroll, R. P. Thornton, and D. C. Sisson. 2005. Identifying predators at northern bobwhite nests. Journal of Wildlife Management 69:124-132.

Thompson, F. R., and D. E. Burhans. 2004. Differences in predators of artificial and real songbird nests: Evidence of bias in artificial nest studies. Conservation Biology 18:373-380.

Thompson, F. R., W. Dijak, and D. E. Burbans. 1999. Video identification of predators at songbird nests in old fields. Auk 116:259-264.

Tigas, L. A., D. H. Van Vuren, and R. M. Sauvajot. 2003. Carnivore persistence in fragmented habitats in urban southern California. Pacific Conservation Biology 9:144-151.

U.S. Census Bureau. 2000. Population Estimates Program, Washington D.C.

VerCauteren, K. C., M. M. McLachlan, and M. J. Pipas. 2003. Nicarbazin-treated feed for reducing reproductive success of penned Canada geese. in T. J. Moser, R. D. Lien, K. C. VerCauteren, K. F. Abraham, D. E. Andersen, J. G. Bruggink, J. M. Coluccy, D. A. Graber, J. O. Leafloor, D. R. Luukkonen, and R. E. Trost, editors. Proceedings of the 2003 International Canada Goose Symposium, Madison, Wi.

Vermeer, K. 1970. A study of Canada Geese, Branta canadensis, nesting on islands in southeastern Alberta. Canadian Journal of Zoology 48:235-240.

Wang, Y., and D. K. Moskovits. 2001. Tracking fragmentation of natural communities and changes in land cover: applications of landsat data for conservation in an urban landscape (Chicago Wilderness). Conservation Biology 15:835-843. 
Way, J. G., I. M. Ortega, and E. G. Strauss. 2004. Movement and activity patterns of eastern coyotes in a coastal, suburban environment. Northeastern Naturalist 11:237-254.

Werner, S. J., and L. Clark. 2006. Effectiveness of a motion-activated laser hazing system for repelling captive Canada geese. Wildlife Society Bulletin 34:2-7.

White, G. C., and K. P. Burnham. 1999. Program MARK: Survival estimation from populations of marked animals. Bird Study 46 Supplement:120-138.

Zoellick, B. W., H. M. Ulmschneider, B. S. Cade, and A. W. Stanley. 2004. Isolation of Snake River islands and mammalian predation of waterfowl nests. Journal of Wildlife Management 68:650-662. 


\begin{tabular}{|c|c|c|c|c|}
\hline Nest Fate & & $\begin{array}{c}\text { Number of } \\
\text { nests monitored } \\
\text { with plasticine } \\
\text { eggs }\end{array}$ & $\begin{array}{l}\text { Number of } \\
\text { nests } \\
\text { monitored }\end{array}$ & $\begin{array}{c}\text { Number of } \\
\text { nests monitored } \\
\text { with video } \\
\text { camera }\end{array}$ \\
\hline \multirow[t]{7}{*}{ Successful } & & 66 & 107 & 6 \\
\hline & $\begin{array}{l}\text { Number of nests } \\
\text { partially depredated } \\
\text { prior to nest }\end{array}$ & & & \\
\hline & termination & 21 & 27 & 2 \\
\hline & $\begin{array}{l}\text { Number of nests where } \\
\text { all eggs were } \\
\text { depredated prior to nest }\end{array}$ & & & \\
\hline & termination & 0 & 0 & 0 \\
\hline & $\begin{array}{l}\text { Number of predation } \\
\text { events prior to nest }\end{array}$ & & & \\
\hline & termination & 27 & 35 & 4 \\
\hline \multirow[t]{7}{*}{ Depredated } & & 93 & 139 & 26 \\
\hline & $\begin{array}{l}\text { Number of nests } \\
\text { partially depredated } \\
\text { prior to nest }\end{array}$ & & & \\
\hline & termination & 28 & 28 & 8 \\
\hline & $\begin{array}{l}\text { Number of nests where } \\
\text { all eggs were } \\
\text { depredated prior to nest }\end{array}$ & & & \\
\hline & termination & 12 & 13 & 4 \\
\hline & $\begin{array}{l}\text { Number of predation } \\
\text { events prior to nest }\end{array}$ & & & \\
\hline & termination & 141 & 195 & 37 \\
\hline \multirow[t]{7}{*}{ Deserted } & & 32 & 38 & 4 \\
\hline & $\begin{array}{l}\text { Number of nests } \\
\text { partially depredated } \\
\text { prior to nest }\end{array}$ & & & \\
\hline & termination & 14 & 16 & 3 \\
\hline & $\begin{array}{l}\text { Number of nests where } \\
\text { all eggs were } \\
\text { depredated prior to nest }\end{array}$ & & & \\
\hline & termination & 3 & 4 & 1 \\
\hline & $\begin{array}{l}\text { Number of predation } \\
\text { events prior to nest }\end{array}$ & & & \\
\hline & termination & 32 & 35 & 11 \\
\hline
\end{tabular}

Table 1.1. Nest predation information for each fate for Canada goose nests monitored in 2005 using 3 different predator monitoring techniques. 


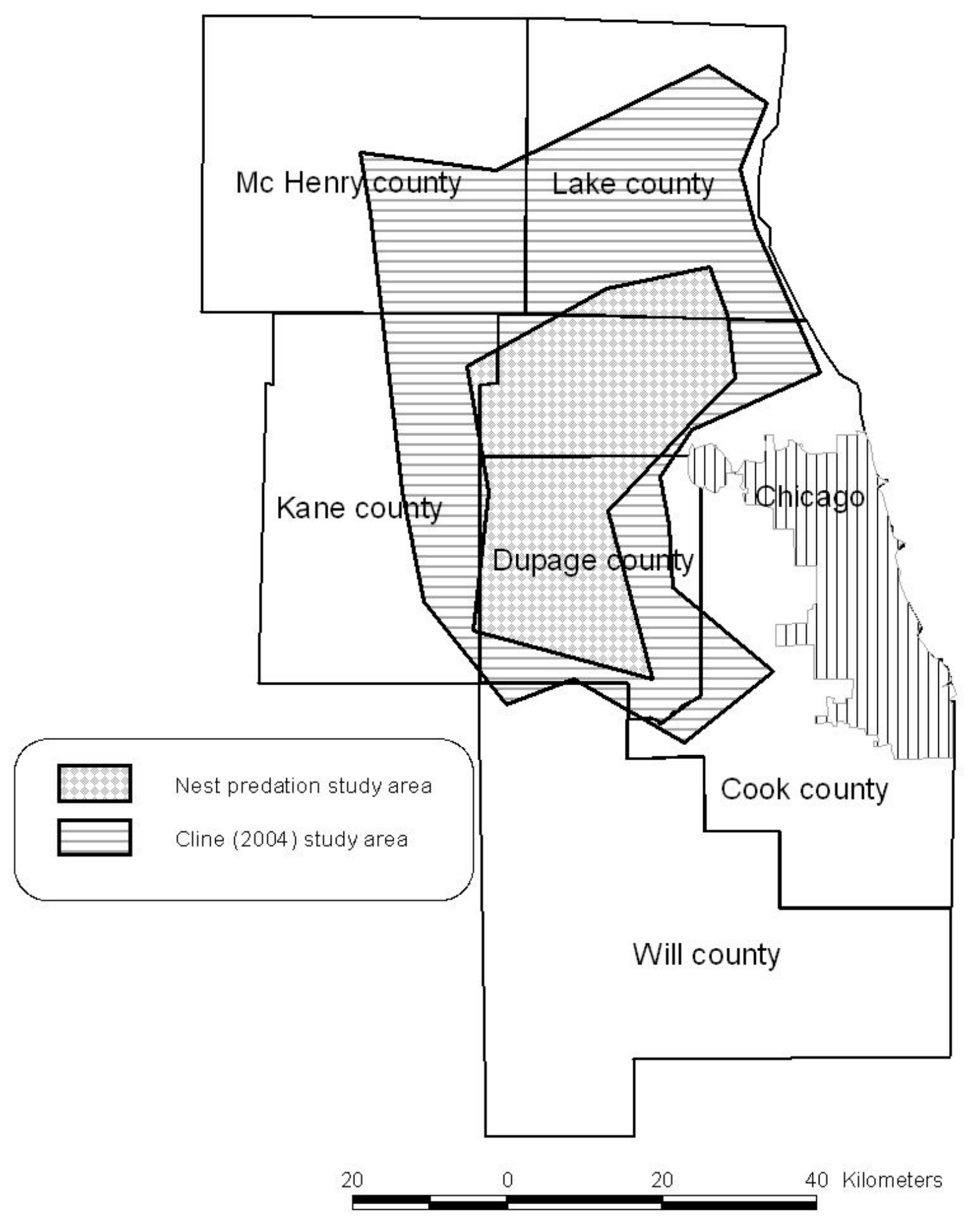

Figure 1.1. Current study area and study area of Cline (2004) and Paine et al. (2003) in the Chicago metropolitan area. 


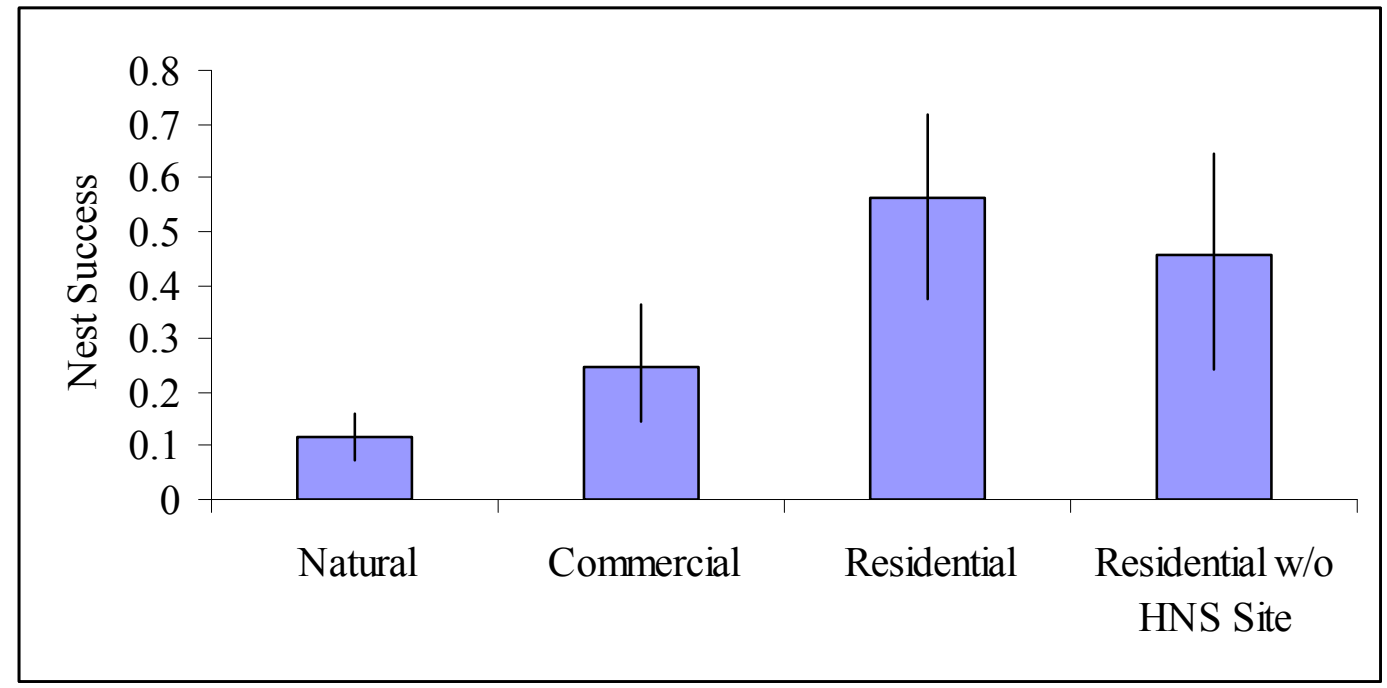

Figure 1.2. Nest success for nests within 3 land-use types during 2005 in the Chicago metropolitan area. 


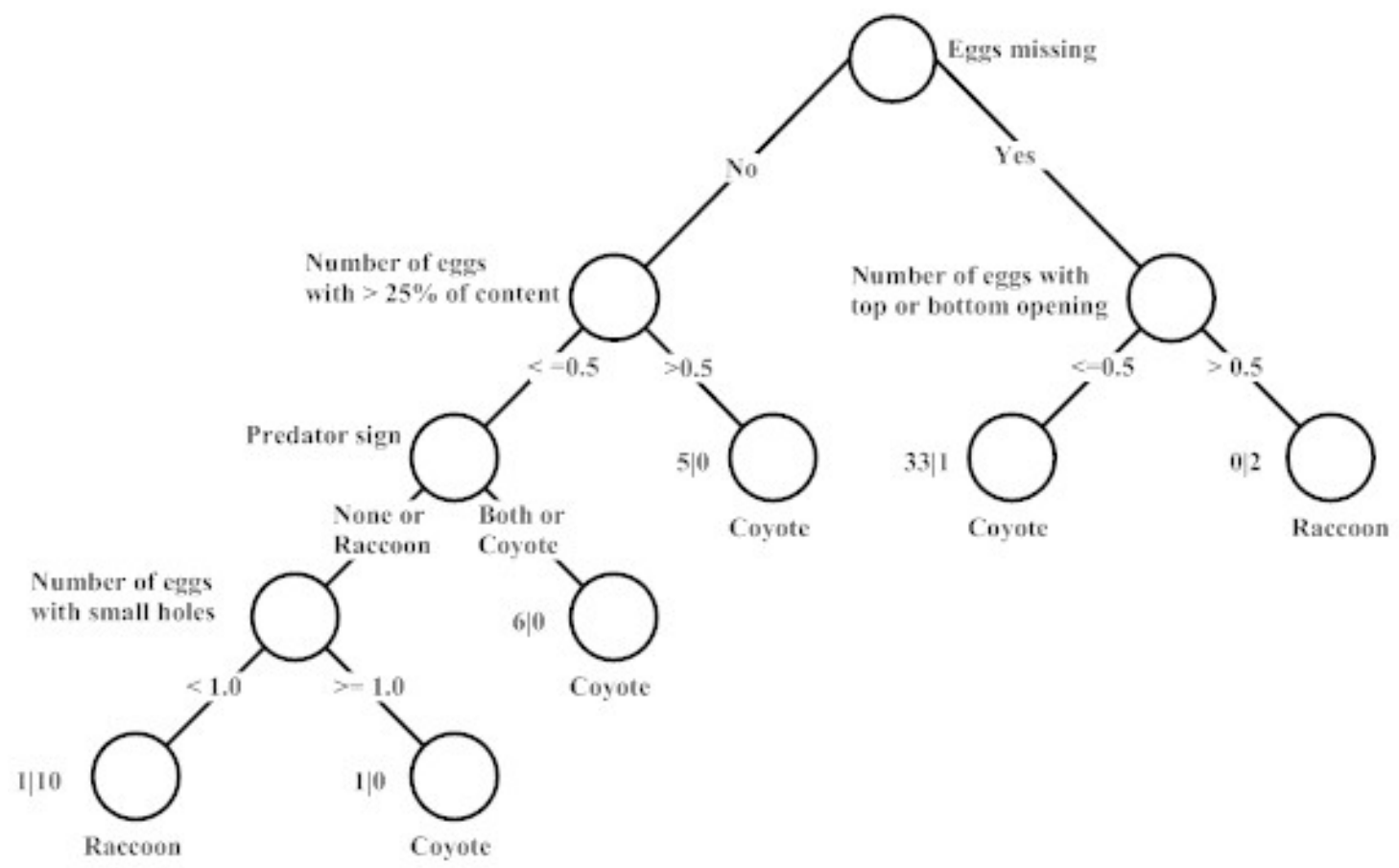

Figure 1.3. Classification tree created from sign collected at nests in the Chicago metropolitan area during 2005 and used to identify nest predator for depredated nests from which the predator was unable to be positively identified. The value beneath each terminal node is the predicted class for that node and the number next to each terminal node is the number of learning samples for each class in the node (e.g. Coyote | Raccoon). The splitting rule for each intermediate node is next to the node. 


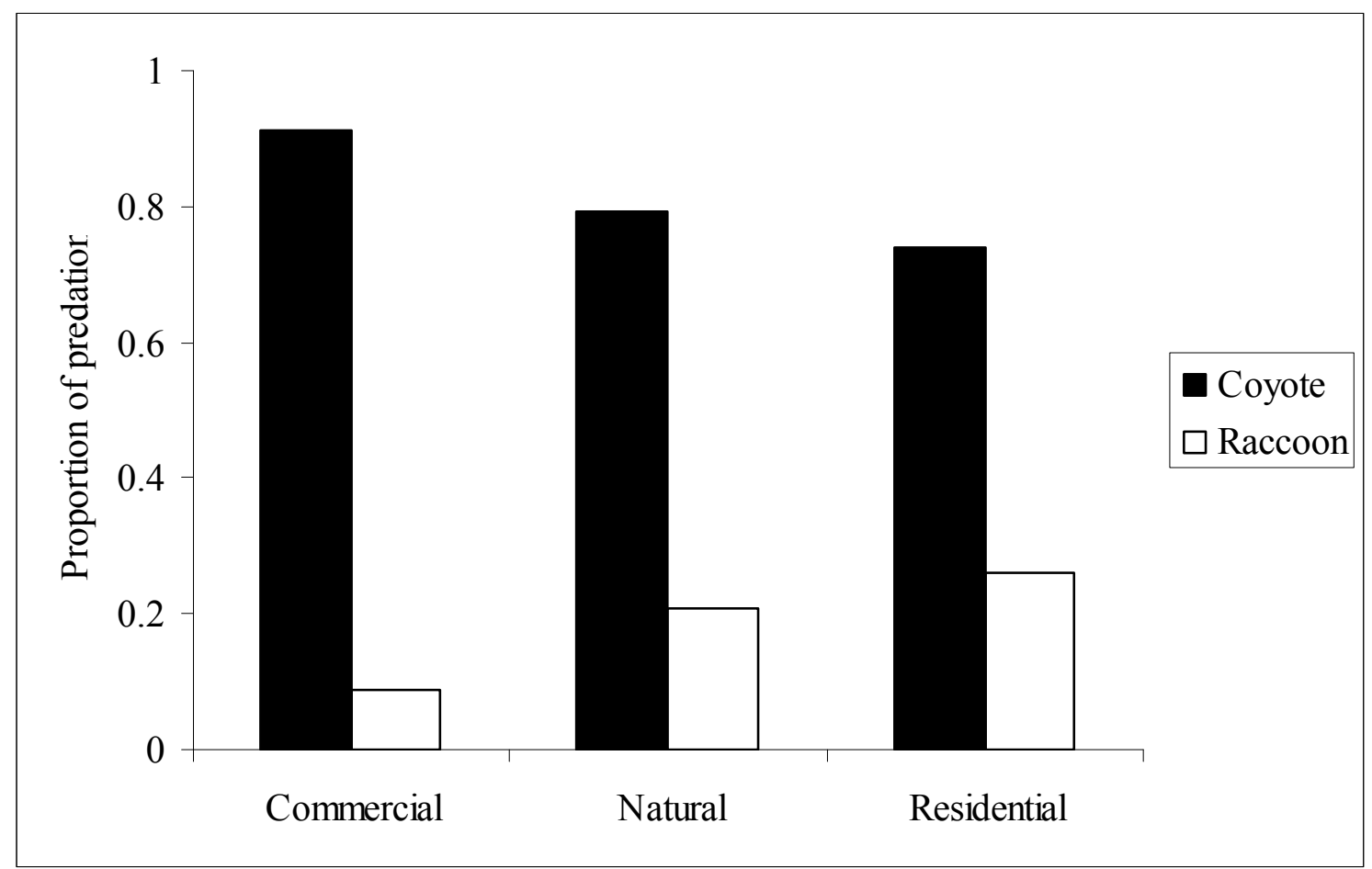

Figure 1.4. Proportion of depredated nests depredated by coyotes and raccoons (nest predator was identified using sign from nest) within each land use type in the Chicago metropolitan area during the 2005 nesting season. 


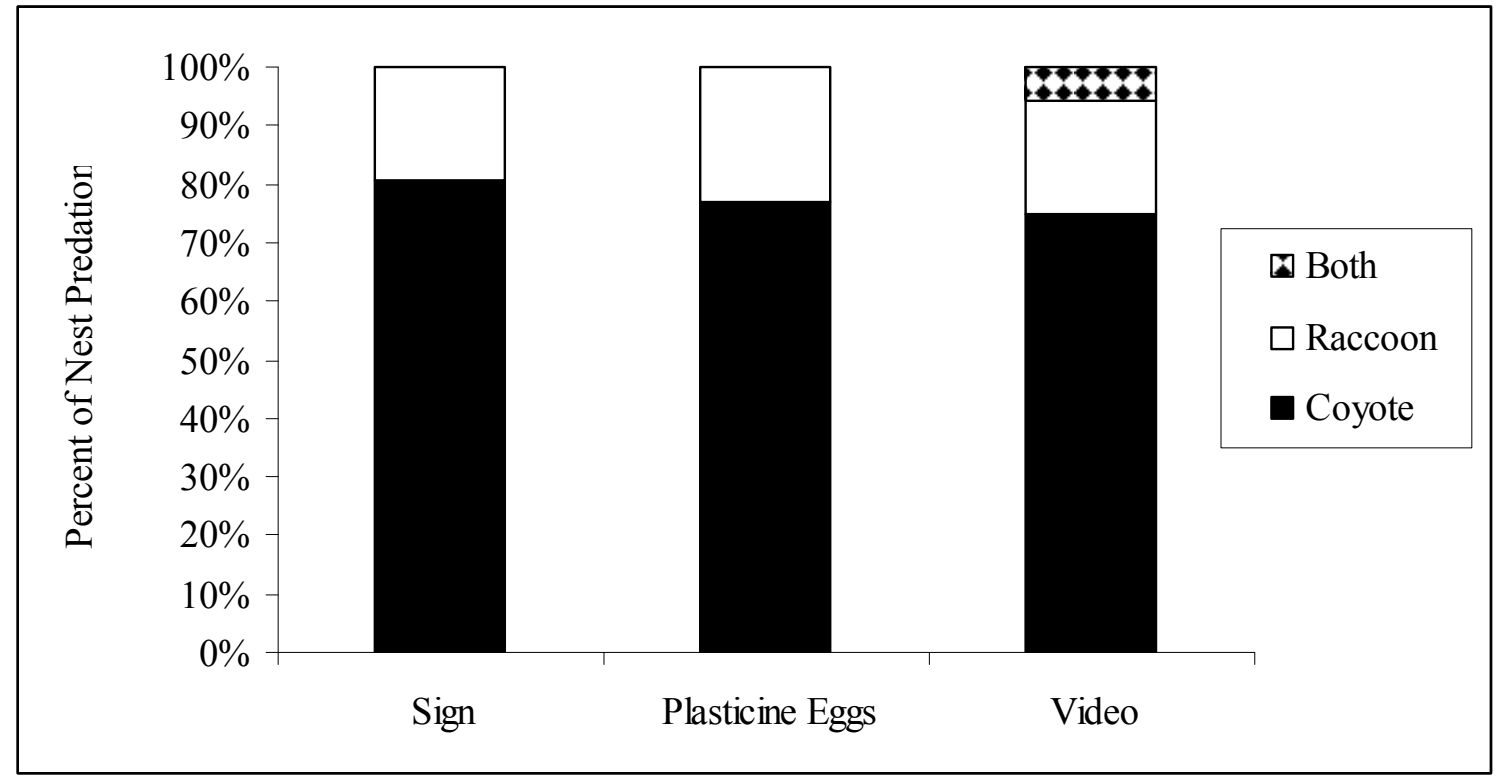

Figure 1.5. Proportion of nests depredated by each nest predator in the Chicago metropolitan area during 2005, identified using 3 different techniques. 


\section{CHAPTER 2}

\section{COYOTE HABITAT SELECTION RELATIVE TO CANADA GOOSE NESTING ACTIVITY IN A METROPOLITAN AREA}

\section{INTRODUCTION}

Coyotes (Canis latrans) were unknown to European settlers of eastern North America prior to 1804 when Lewis and Clark first glimpsed the species on the eastern edge of Nebraska (Ambrose 1996). Since then, coyote populations have dispersed throughout most of North America due to various factors (Bekoff 1977). Wolf (Canis lupus) eradication programs aided coyotes by eliminating interference competition and reducing direct predation. Wolves reduced or eliminated coyotes by killing or excluding them from their territories (Crabtree and Sheldon 1999, Smith et al. 2003, Arjo and Pletscher 2004). Habitat alteration via logging and conversion of land to agriculture has promoted the spread of coyotes to these new open habitats (Gompper 2002b). Translocation of coyotes into uninhabited regions hastened the spread of coyotes and possibly allowed colonization of particular regions (Bekoff 1977, Hill et al. 1987, Gompper 2002b). Today coyotes have habituated and thrive in, human-dominated 
environments, such as large cities and suburban areas (Quinn 1997b, Grinder and Krausman 2001, Gompper 2002a, Tigas et al. 2002, Atwood et al. 2004, Morey 2004).

Coyotes have become a common top-level predator in many metropolitan areas during the past few decades, making them potentially important for urban wildlife populations (Crooks and Soule 1999, Gompper 2002a, Gehrt 2006). Coyotes exert pressure on many wildlife species that have experienced little predation risk in the urban environment. Coyotes are highly opportunistic and commonly consume rodents and deer with lagomorphs, plant matter, anthropogenic food sources and birds fed on less frequently (McCracken 1982, Atkinson and Shackleton 1991, Quinn 1997a, Morey 2004). Although it has not been demonstrated in urban environments, coyotes have been found to prey on many ground nesting bird species (Fichter et al. 1955, Vermeer 1970, Fitzner and Rickard 1983, Sargeant et al. 1998, Staller et al. 2005).

Canada geese (Branta canadensis) were an abundant prey source that could be found throughout the Chicago metropolitan area and had exhibited exponential population growth. Geese become highly clumped during the nesting season providing a highly available super rich seasonal food source. The clumped nature of Canada geese during the nesting season may provide an opportunity for coyotes to concentrate hunting efforts to find large numbers of eggs and vulnerable individuals.

Coyotes have been found to potentially limit Canada goose populations through nest predation in the Chicago metropolitan area (Chapter 3). Due to the lack of egg shells in scat few coyote dietary studies have found Canada geese (Korschgen 1957, Cypher 1993) or other bird eggs (Fichter et al. 1955, Cypher 1993, Cypher et al. 1996) as part of the coyote diet. Coyote feeding behavior with eggs allow them to consume the egg 
content without consuming egg shells as they typically cracked the egg open and licked up the contents (Sooter 1946). Morey (2004) found no sign of egg remains in coyote scat even though coyotes were seen eating goose eggs.

Canada goose eggs can serve as an important energy source for coyotes. A single Canada goose egg provides enough energy $(399 \mathrm{kcal})$ to meet a $12.9 \mathrm{~kg}$ coyote's daily basal metabolic rate (BMR) of 399 - $643 \mathrm{kcal}$ (Litvaitis and Mautz 1980, Golightly and Ohmart 1983). Free living animals need to consume 2.65 times the amount of energy that is required for daily basal metabolic activities to support average daily energy requirements (Karasov 1992). The maximum metabolic demand for a coyote occurs during the lactation phase and is estimated to be 2,429 Kcal/day (Laundre and Hernandez 2003). Since Canada geese have an average of 5.5 eggs per nest (Cline 2004), a coyote has the potential to obtain $117 \%-140 \%$ of its annual daily energy needs or $82 \%-97 \%$ of the daily energy needs during lactation from a single nest. The large amount of energy available in a goose egg would make it beneficial for coyotes to search for goose eggs, as they can provide an important energy source throughout late gestation and early pup rearing. In addition to goose eggs, coyotes occasionally depredate adult geese, which also provide an energy source, and may motivate coyotes to search for nesting geese that may be more vulnerable to predation (Chapter 1). The energy available in goose eggs at nesting sites with a large quantity of nests could sustain a coyote for more than one month during their lactation phase when energy demands are at their greatest.

Optimal foraging theory predicts that an animal should optimize its time spent in food patches based on resource levels and predation risk (Stephens and Krebs 1981). Thus, coyotes should maximize time feeding in areas with the highest quality prey and 
minimal contact risk with humans, the only predator of coyotes in the area. Little is known about how coyotes shift foraging patterns in urban areas with changes in food availability. Studies have pointed out that coyotes in urban environments prefer undeveloped areas to highly developed areas for activities such as foraging, resting or denning (Quinn 1997b, Way et al. 2004). However, they will forage in residential areas and urban-grasslands and travel through highly developed environments to reach undeveloped habitats (Shargo 1988, Grinder and Krausman 2001, Tigas et al. 2002). Urban fragmentation impacts coyote movement and use of available resources (Swihart et al. 2001, Bolger 2002, Crooks 2002, Riley et al. 2003, Tigas et al. 2003). Resource use by predators and prey in a fragmented landscape is important in discerning predator-prey interactions. Prey location and the effects of fragmentation can influence the way that predators use the landscape (Swihart et al. 2001, Riley et al. 2003).

It is unclear whether coyotes actively hunt Canada geese or only depredate nests when they fortuitously come into contact with nests while searching their territory or hunting for other prey. Coyotes have been shown to use habitats equal to availability with increasing prey densities and or prey vulnerability (Patterson and Messier 2001, Randa and Yunger 2004). The degree to which coyotes are able to detect and actively prey on a seasonally available avian food source is unknown and it has been hypothesized that coyotes only take birds that are accidentally encountered (Sperry 1941, Fichter et al. 1955). To examine if coyotes were actively searching for Canada goose nests or opportunistically taking advantage of available nests, I determined whether coyotes shift habitat selection in response to distribution or availability of Canada goose nests (Cline 2004). 
I compared coyote habitat selection within home ranges for pre, post and during the Canada goose nesting season. My objectives were to: (1) associate habitat types with the distribution of Canada goose nests, and (2) determine if coyotes shift habitat selection toward nesting habitats during the Canada goose nesting season relative to pre and postnesting seasons. I hypothesize that coyotes will increase their use of habitats that contain the largest number of goose nests during the nesting season to take advantage of this seasonally available prey.

Study area

Field work was conducted in a $1059 \mathrm{~km}^{2}$ area within northwestern Cook, northern DuPage, southeastern McHenry, and eastern Kane counties in the Chicago metropolitan area. These counties were in the top 6 most populated counties in Illinois with 2 of the 4 counties in the top 50 most populated counties in the country (U.S. Census Bureau 2000). Cook County was the second most populated county in the country with an estimated 5.4 million people (U.S. Census Bureau 2000). Urban development was substantial such that a $1769 \mathrm{~km}^{2}$ area centered on downtown Chicago has seen an $62 \%$ increase in urban land from 1985 to 1997 (Wang and Moskovits 2001).

Elevation of the Chicago region is approximately $200 \mathrm{~m}$ above sea level with very little change in topography. Precipitation in Chicago averages $96.5 \mathrm{~cm}$ per year with mean high and low nesting season (March-June) temperatures of $27^{\circ} \mathrm{C}$ and $0{ }^{\circ} \mathrm{C}$ (http://www.weather.com/weather/climatology).

Plant communities in northeast Illinois include forest, flatwood, open woodland, savanna, prairie, marsh, shrub swamp, sedge meadow, fen and bog (Sullivan 2000). 
Landscape in the Chicago metropolitan area was dominated by developed urban-land (30.5\%), followed by agriculture (25.1\%), rural grassland (12.9\%), forest $(12.5 \%)$, urbangrassland (12.2\%), and wetlands or open water (6.3\%) (Paine et al. 2003). The 4 counties in which the project was conducted consisted of approximately $11.5 \%$ open space (e.g. forest preserves, parks, natural areas, publicly owned golf courses, and private lands with a permanent open space easement) (Openlands Project 1999).

\section{METHODS}

Distribution of Canada goose nests

I used data from Cline (2004) to map the distribution of Canada goose nests in the Chicago metropolitan area. They identified and surveyed 6 different land use types for goose nests: commercial, residential, campuses, city parks, golf courses, and preserves (Paine et al. 2003, Cline 2004). Sites that were subject to human disturbance, such as hazing and egg destruction, were not used unless it was not avoidable. See Cline (2004) or Paine et al. (2003) for a further description of site selection. All study sites contained wetlands or deepwater habitats. Aerial surveys indicated that goose nests were typically near water (C. Paine, Max McGraw Wildlife Foundation, unpublished data). Nest searching was conducted by canoeing, walking, and driving sites looking for nests.

The previous nesting study monitored a total of 2131 nests over the 3 year period. Total number of nests monitored per year ranged from 404 nests in 2000 to 1008 nests in 2002. All nest locations were recorded in Universal Transverse Mercator coordinates (UTMs) and were monitored on a weekly basis. 
To relate goose nesting habitat to coyote habitat use I reclassified goose nest habitat type by placing their UTM locations over the habitat map that was used for the coyote resource selection analysis. To identify habitats that contained the most nests I pooled nests over the 3 years and calculated the proportion of nests in each habitat type.

Coyote movements and habitat use

As part of a long term ecological study (Gehrt 2004, Morey 2004, Gehrt 2006), coyotes were captured between March 2000 - September 2006 using No. 3 offset padded foothold traps (Victor Soft-catch Coilspring, Lititz, Pennsylvania, USA) and non-lethal neck snares. Coyotes were immobilized using Telazol, and subsequently were aged, sexed, measured, weighed, ear tagged and any coyote above $3.5 \mathrm{~kg}$ was fitted with a 155 g radio collar (Advanced Telemetry Systems, Isanti, Minnesota, USA). Coyotes were released at capture locations. All animals were handled and processed following protocols approved by the Animal Care and Use Committee at the Ohio State University under permit number 2003R0061.

Coyotes were located using a single observer technique from a vehicle equipped with a 4-element Yagi antenna (White and Garrot 1990). LOCATE II (Pacer, Truro, Nova Scotia, Canada) was used to triangulate locations using $\geq 2$ bearings. Any calculated location with a triangulation error ellipse $>5$ ha was discarded. Reference collars were used to estimate the location error rate, $108 \pm 87 \mathrm{~m}( \pm \mathrm{SD})$. Locations were recorded to the nearest meter using the Universal Transverse Mercator (UTM) grid system. Error rate was high for many coyote locations because many were estimated when the collared animal was seen or when the coyote was located in a restricted area or 
small patch. Observer presence during telemetry did not appear to influence coyote behavior in the study area as they were habituated to vehicle and pedestrian traffic.

Diurnal locations were recorded $\geq 2$ times per week (mean $=2.8$ times per week) and separated by 1 night to allow independent movement between locations. Sequential tracking sessions of 5 locations taken hourly were conducted during nocturnal and crepuscular tracking sessions to observe landscape use (Grinder and Krausman 2001, Way et al. 2004). Nocturnal coyote tracking sessions were separated by $\geq 1$ night. Nocturnal locations were recorded during all time periods between dusk and dawn. Coyote locations were recorded every $10 \mathrm{~min}$ in 2002, opposed to all other years when locations were taken $\geq 45 \mathrm{~min}$ apart. All radio locations from 2002 that were not $45 \mathrm{~min}$ apart were dropped from the analyses. Time between bearings on all coyotes was $\leq 5$ minutes with bearings in 2002 recorded $\leq 3$ minutes apart.

To determine available habitat in relation to goose nests I calculated $95 \%$ Minimum Convex Polygon (MCP) home ranges from locations recorded between December 10 and September 14 for the year that an individual coyote had enough locations to meet the following requirements. To use a it had to have $\geq 20$ nocturnal locations and $\geq 10$ diurnal locations recorded during the nesting season and either pre or post-nesting seasons. To reduce autocorrelation from sequential locations, only locations $\geq 45$ min apart were used. The home range extension (Rodgers and Carr 2002) in Arcview 3.2 Geographical Information System (GIS) software (Environmental Systems Research Institute, Redlands California, USA) was used to calculate and plot 95\% MCP home range estimates. The $95 \% \mathrm{MCP}$ fit the disjunct urban coyote home ranges without exaggerating boundaries on all sides of the home range. Shivik and Gese (2000) 
recommended use of MCP to calculate coyote home ranges as they found it to have been the most accurate model available for coyotes.

Resource selection

Chicago Wilderness and NASA Landsat Thematic Mapper images with $28.5 \mathrm{~m}$ resolution in Arcview GIS software were used to create habitat maps. Original files consisted of 164 land-use/habitat classifications (Appendix C) that I reclassified into 6 habitat types: agriculture, grassland, urban-grass, urban-land, woodlands, and buffer (Table 2-1). The reclassified habitat map was used to analyze coyote resource selection. Habitat availability was calculated for each coyote that exceeded the minimum requirements that were set prior to calculating 9 month home ranges. The use of each habitat was calculated by counting the number of telemetry points that occurred within each habitat type.

Habitat selection for the 3 seasons: nesting (March 13 - June 13), pre-nesting (December 10 or 11 - March 12) and post-nesting (June 14 -September 14) were compared using third order habitat selection (Johnson 1980) with compositional analysis (Aebischer et al. 1993). Habitat selection during each season was ranked in order with 5 the most selected to zero the least selected based on mean log ratio differences (Aebischer et al. 1993). I only ran third order habitat selection as it compared animal locations to the available habitat within an animal's home range. Second order habitat selection was not tested, as use is the proportion of each habitat type in an animal's home range while availability is assigned by using an artificial boundary such as a park boundary. Second order was not appropriate for urban coyotes as there is no accurate 
way to assign boundaries in a species that ranges between land-use types. Additionally, coyotes are highly territorial making areas outside their home range unavailable due to the defense of the area by another coyote pack.

A repeated measures MANOVA was used to detect changes in habitat selection by coyotes between seasons (Manly et al. 2002). Log ratio differences (di) were calculated using the equation:

$$
d i=\ln \left(\frac{X_{u i}}{X_{u j}}\right)-\ln \left(\frac{X_{a i}}{X_{a j}}\right)
$$

where $\mathrm{a}=$ available habitat, $\mathrm{u}=$ used habitat, and $\mathrm{i}, \mathrm{j}=$ habitat types. To conduct the repeated measures MANOVA, difference in di values were taken between seasons (nesting season and pre-nesting season or nesting season and post-nesting season). The difference in log ratios between seasons was used in a MANOVA to test if there was any difference in habitat selection between seasons. Any habitat that was not used by a coyote had a 0.003 substituted as recommended by Bingham and Brennan (2004). No groups were compared using compositional analysis because each group was required to have a minimum of 6 individual coyotes to allow comparison (Aebischer et al. 1993).

Compositional analysis (Aebischer et al. 1993) was conducted using Resource Selection for Windows software (Leban 1999) to test for habitat selection of coyotes in pre, post and during nesting seasons. Compositional analysis has 2 advantages: 1) it uses the individual as the sampling unit rather than telemetry locations, eliminating pseudo- 
replication, and 2) it avoids problems of avoidance of one resource leading to selection of others (Aebischer et al. 1993). Available habitat for each coyote was calculated by determining the percent of each habitat in each individual's 9 month home range. Seasonal use was calculated by counting the number of locations in each habitat for the individual coyote and averaging the number of locations in each habitat with the number of total locations during that same season. Coyotes from the same pack were assumed to have been independent if they were within $100 \mathrm{~m}$ of each other for $<25 \%$ of all telemetry locations.

\section{RESULTS}

As part of the larger coyote study a total of 265 coyotes were captured during March 2000 - September 2006 of which 184 were equipped with radio collars. From this pool of radio collared coyotes, I identified 19 (14 males and 5 females) coyotes that had sufficient locations for habitat comparisons between seasons. One coyote was used twice in the analysis and considered independent because it switched social status from solitary to resident and reduced its home range to $20 \%$ of its previous size. The resident home range occurred completely within the larger solitary home range. To identify a switch in habitat selection between pre-nesting and nesting season a total of 1874 locations were used from 12 coyotes. To identify any change in coyote habitat selection between postnesting and nesting season, 2660 locations were used from 19 coyotes. Mean home range size of resident and solitary coyotes used in the compositional analysis was $5.72 \mathrm{~km}^{2} \pm$ $0.76($ mean $\pm \mathrm{SE})$ and $53.51 \mathrm{~km}^{2} \pm 7.12($ mean $\pm \mathrm{SE})$. 
Buffer habitat was the primary nesting habitat for Canada geese. Nearly all (90\%) goose nests found during Cline's (2004) nesting study were in the buffer habitat (Figure 2.1). Of all nests in the buffer habitat $48 \%$ were successful and $31 \%$ of nests were depredated. Nest predation rate was consistent through most of the nesting season with a peak in late April (Figure 2.2).

Coyotes exhibited habitat selection during pre-nesting $\left(X^{2}=14.638, P<0.05\right.$, $n=12)$ and nesting $\left(X^{2}=23.095, P<0.001, n=12\right)$ seasons (Figure 2.3), but selection between seasons was similar (Wilks $\lambda=0.841, P=0.72$ ). Coyote selection of buffer habitat was ranked first in both pre-nesting season and nesting season (Table 2.2). During the pre-nesting season coyotes selected buffer habitat more than all other habitat types $(\mathrm{t}=2.44, P=0.038)$.

Coyotes did not use habitat in the same proportion as available during both nesting $\left(X^{2}=31.276, P<0.01, n=19\right)$ and post-nesting $\left(X^{2}=19.857, P<0.05, n=19\right)$ seasons (Figure 2.4), but coyote use relative to availability was similar between seasons (Wilks $\lambda=0.491, P=0.07)$. Buffer habitat dropped from the most used or top ranked habitat during the nesting season to the third ranked habitat during the post-nesting season (Table 2.3). During the post-nesting season selection of buffer habitat was not significantly different than grassland $(t=-1.542, P=0.141)$ and woodland $(t=0.8811, P=0.39)$, the top 2 ranked habitats.

Use of buffer habitat by coyotes increased from the start of pre-nesting and peaked during the first month (March 16 - April 15) of the nesting season. Buffer habitat received the most use even though it was not the most selected during all seasons. During the second month of the nesting season coyotes began to use woodlands more 
frequently while reducing their use of the buffer habitat. Less than $20 \%$ of coyote locations during all seasons fell within urban-land, urban-grass and agricultural habitats (Figure 2.5).

\section{DISCUSSION}

Nests were highly aggregated with $90 \%$ of all nests occurring in the buffer habitat. Although nest searching efforts were concentrated around water, I believe that the estimate of the proportion of nests occurring in the buffer habitat is accurate. Aerial surveys indicated that most goose nests were located near water (Paine et al. 2003) and few nests were found in all other habitat types. Cline (2004) conducted surveys up to 200 $\mathrm{m}$ away from the water where the created buffer habitat was only $50 \mathrm{~m}$ from the water edge. All other habitats contained few nests, thus making them relatively unimportant for Canada goose nesting (see Figure 2.1).

Pre-nesting vs. nesting season habitat selection

During pre-nesting and nesting seasons coyotes used buffer habitat more than any other habitat type. The disproportionate use of the buffer habitat during both pre-nesting and nesting seasons indicates that coyotes exploited similar resources during both seasons. Furthermore, the high use of buffer habitat during both seasons indicates that coyotes were present at the initiation of the nesting season and did not need to switch habitats in order to exploit the abundant goose nests.

Coyotes' disproportionate use of buffer habitat during both pre-nesting and nesting seasons may have been related to the availability of sufficient cover. Coyotes were most often found in habitats that provided sufficient cover during both movements 
and resting (Andelt and Andelt 1981, Quinn 1997b, Gosselink et al. 2003). During prenesting and most of the nesting season, cover was a primary concern as very little herbaceous vegetation was available in 2 of the top 3 ranked habitats (grassland and woodland habitats) whereas cattails (Typha spp.) provided abundant cover in the buffer habitat. Furthermore, coyotes were found frequently using cattail marshes during radio telemetry tracking and during flights conducted to estimate pack size during the Canada goose pre-nesting season (Gehrt Unpublished data).

Other factors may also influence coyote habitat selection during pre-nesting and nesting seasons, such as reproductive status and prey resource availability (Harrison and Gilbert 1985, Gosselink et al. 2003, Kamler et al. 2005). Coyotes typically give birth during the nesting season causing them to spend more time at dens, which may cause them to alter their habitat use during the nesting season compared to that in the prenesting season. During the pre-nesting season prey vulnerability may increase with freezing and snowy conditions, thus influencing coyote habitat selection (Brundige 1993). Cottontail rabbits (Sylvilagus floridanus) occurred more frequently in coyote scat than other prey items during the pre-nesting season, when snow fall can increase vulnerability of rabbits to predation (Keith and Bloomer 1993, Morey 2004). Increased vulnerability may cause coyotes to concentrate hunting efforts in areas with an abundant cottontail population. Although cottontails can be abundant in several habitat types (Swihart and Yahner 1984, Rosenblatt et al. 1999, Morey 2004), a lack of information concerning the prey density in each habitat made it impossible to identify if these prey items were responsible for changes in coyote use of buffer habitat between pre-nesting and nesting seasons. 
Nesting vs. post-nesting season habitat selection

Coyote selection of buffer habitat went from top ranked during the nesting season to third ranked in the post-nesting season, which suggests that coyotes' switched habitat selection due to the change in resource availability. The loss of goose nests was likely partly responsible for this change as coyotes were the primary predator of Canada goose eggs in the Chicago area (Chapter 1). Furthermore, coyotes increased their hunting efforts on Canada goose nests during a small part of the nesting season, as the percentage of active nests that were depredated peaked just after the peak in nest initiation, which then declined as nests became less available through the nesting season. This change in predation rate supports the idea that coyotes showed selection for goose nesting habitat, as they were able to exploit nests as they became available. Coyotes with large nesting areas in their home range during the nesting season likely fed heavily on goose eggs. Although the switch in habitat use was partially due to the disparity in availability of goose nests between seasons, goose nests were not the sole cause for the decreased use of buffer habitat during the post-nesting season. Other factors were likely influencing coyote use of buffer habitat, because buffer habitat was used during pre-nesting and nesting seasons at similar frequencies. Since coyotes were using the buffer habitat prior to nests becoming available, I was unable to discern to what degree the use of buffer habitat was influenced by coyote nest searching during the nesting season.

Identifying reasons for the drop in ranking of the buffer habitat from nesting season to post-nesting seasons was confounded by many factors. 1) Pup-rearing, which occurs from the last half of pre-nesting season through the post-nesting season, may influence coyote habitat use as coyotes obtain higher quality prey for their pups (Harrison 
and Harrison 1984, Cypher et al. 1996). During pup-rearing coyotes also expand their home range size and travel farther distances (Patterson et al. 1999, Servin et al. 2003), both of which could influence habitat use by coyotes. 2) Increases in cover within grassland and woodland habitats due to plant growth during the last half of the nesting season and all of the post-nesting season. Cover is an important habitat characteristic that influences coyote habitat use as they increased their use of both grassland and woodland habitats during the post-nesting season. 3) Coyotes switch use of habitats based on seasonal abundance of prey or changes in prey vulnerability (O'Donoghue et al. 1998, Patterson et al. 1998, Patterson and Messier 2001). Changes in habitat selection between seasons can be due to several factors such as cover, territoriality, reproductive status, and/or food availability, making it difficult to interpret results.

The peak use of buffer habitat by coyotes occurred during the same time period as the peak in nest initiation ( March 29) (Paine et al. 2003), which supports the idea that coyotes were actively hunting Canada goose nests. The delay between the peak in nest predation and the peaks in buffer habitat use and nest initiation, likely occurred because coyotes were focusing their efforts on sites where goose nests were aggregated. It could have taken a coyote several weeks to depredate all of the eggs from nest sites with large numbers of nests, creating the delay that is seen in peak nest predation. The aggregation of nests in certain areas of buffer habitat allow coyotes to feed on readily available goose eggs, while spending more time attending to pups, defending the territory or hunting other prey. Alternatively, the peak in the high predation rate occurring after the peak in buffer habitat use can be explained by increased intraspecific strife as geese become more abundant and start competing for the best nesting sites. As geese compete for nesting 
sites they make more noise, which may have attracted coyotes allowing them to find nesting sites without actively searching for goose nests.

Factors influencing coyote habitat selection

It is difficult to relate habitat selection to habitat variables as coyotes are territorial and generalist predators. Territory maintenance may cause coyotes to use certain habitats more than expected based on available resources. Maintenance of territories may include defensive measures, scent marking using urine and/or feces or scratching in soil (Barrette and Messier 1980, Gese and Ruff 1997). Territorial activities such as maintenance and defense can influence coyote habitat use and may restrict the amount of time that can be spent at an available food source. Maintenance and defense of a territory could affect habitat selection as coyotes in Yellowstone National Park were observed for $2507 \mathrm{hrs}$ and were identified defending their territory 112 times, or once every 22.4 hrs (Gese 2001), thus demonstrating that coyotes likely spend large amounts of time maintaining territories. The large variation in the number of available nests in each coyotes' home range may explain why coyote use of buffer habitat did not increase between pre-nesting and nesting seasons. Individual coyotes may have been more likely to concentrate on goose nests if they had a large number of nests in their territory. The only coyote home range that was surveyed for goose nests belonged to coyote 27 at the Ned Brown forest preserve (NBFP). The home range was composed of $48 \%$ buffer habitat and contained a large number of goose nests (Cline 2004). Use of buffer habitat by coyote 27 peaked during the pre-nesting season at $51 \%$, nesting season at $62 \%$, and post-nesting season at $47 \%$. The elevated usage of buffer habitat during the nesting 
season appears to be due to the high occurrence of nests at this site. The elevated use of buffer habitat during the nesting season at NBFP as well as the high predation rate $(71 \%)$ of Canada goose nests at this site (Chapter 1) demonstrates that coyotes will concentrate hunting efforts on a seasonally available avian prey source.

Both resident and solitary animals were used in compositional analysis, as they both use Canada goose nesting habitat. Solitary coyotes, which may comprise up to $40 \%$ of the entire population (Windberg et al. 1997) use lower quality habitats between resident coyote home ranges (Kamler and Gipson 2000) allowing them to find nests that resident animals would not find. Furthermore, solitary coyotes may spend more time hunting prey items and less time maintaining territories, making them an important goose nest predator (Gese and Ruff 1997). Although I was not able to statistically compare habitat use between solitary $(n=5)$ and resident $(n=14)$ coyotes, because compositional analysis requires a minimum of 6 individuals per group, their similar use of buffer habitat would allow both social groups to serve as important goose nest predators.

The high predation of goose nests by coyotes make it reasonable that individual coyotes may spend more time looking for goose eggs even though the population as a whole does not (Chapter 1). A single goose egg can provide a substantial amount of energy (399 Kcal) for coyotes during the lactation phase and pup-rearing season when they require the highest amount of energy (2429 Kcal/day) (Carey et al. 1980, Laundre and Hernandez 2003). The average goose nest in the Chicago area contained 5 to 6 eggs, which was enough energy to meet the daily energy requirements of a coyote, making it beneficial for coyotes to search for individual nests as well as sites where geese nest in large aggregations. The high use of preferred nesting habitat by coyotes allows them to 
influence Canada goose populations through nest predation. Additionally, their high use of buffer habitat may influence the Canada goose population by causing geese to avoid certain nesting areas. The avoidance of high quality nesting sites due to the presence of coyotes makes their impact important on further controlling the Chicago metropolitan Canada goose population. 


\section{LITERATURE CITED}

Aebischer, N. J., P. A. Robertson, and R. E. Kenward. 1993. Compositional analysis of habitat use from animal radio tracking data. Ecology 74:1313-1325.

Ambrose, S. E. 1996. Undaunted courage: Meriwether Lewis, Thomas Jefferson, and the opening of the American West. Simon and Schuster, New York.

Andelt, W. F., and S. H. Andelt. 1981. Habitat use by coyotes in southeastern Nebraska. Journal of Wildlife Management 45:1001-1005.

Arjo, W. M., and D. H. Pletscher. 2004. Coyote and wolf habitat use in northwestern Montana. Northwest Science 78:24-32.

Atkinson, K. T., and D. M. Shackleton. 1991. Coyote, Canis latrans, ecology in a ruralurban environment. Canadian Field-Naturalist 105:49-54.

Atwood, T. C., H. P. Weeks, and T. M. Gehring. 2004. Spatial ecology of coyotes along a suburban-to-rural gradient. Journal of Wildlife Management 68:1000-1009.

Barrette, C., and F. Messier. 1980. Scent-marking in free-ranging coyotes, Canis latrans. Animal Behaviour 28:814-819.

Bekoff, M. 1977. Canis latrans. Mammalian Species 79:1-9.

Bingham, R. L., and L. A. Brennan. 2004. Comparison of type I error rates for statistical analyses of resource selection. Journal of Wildlife Management 68:206-212.

Bolger, D. T. 2002. Habitat fragmentation effects on birds in southern California: Contrast to the top-down; paradigm. Studies in Avian Biology 25:141-157.

Brundige, G. 1993. Predation ecology of the eastern coyote, Canis latrans var., in the Adirondacks, New York. Ph.D. Dissertation. State University of New York, Syracuse, New York.

Carey, C., H. Rahn, and P. Parisi. 1980. Calories, water, lipid and yolk in avian eggs. Condor 82:335-343.

Cline, M. 2004. Productivity of giant Canada geese (Branta canadensis maxima) in northeastern Illinois. Masters Thesis. Southern Illinois University of Carbondale, Carbondale.

Crabtree, R. L., and J. W. Sheldon. 1999. Coyotes and canid coexistence in Yellowstone. Pages 127-163 in T. W. Clark, A. P. Curlee, S. C. Minta, and P. M. Kareiva, editors. Carnivores in Ecosystems: the Yellowstone Experience. Yale University Press, New Haven. 
Crooks, K. R. 2002. Relative sensitivities of mammalian carnivores to habitat fragmentation. Conservation Biology 16:488-502.

Crooks, K. R., and M. E. Soule. 1999. Mesopredator release and avifaunal extinctions in a fragmented system. Nature 400:563-566.

Cypher, B. L. 1993. Food item use by coyote pups at Crab Orchard National Wildlife Refuge, Illinois. Transactions of the Illinois State Academy of Science 86:133137.

Cypher, B. L., K. A. Spencer, and J. H. Scrivner. 1996. Use of food items by sex and age classes of coyotes. California Fish and Game 82:42-47.

Fichter, E., G. Schildman, and J. H. Sather. 1955. Some feeding patterns of coyotes in Nebraska. Ecological Monographs 25:1-37.

Fitzner, R. E., and W. H. Rickard. 1983. Canada goose nesting performance along the Hanford reach of the Columbia River, 1971-1981. Northwest Science 57:267-272.

Gehrt, S. D. 2004. Ecology and management of striped skunks, raccoons, and coyotes in urban landscapes. Island Press, Washington D.C.

Gehrt, S. D. 2006. Urban coyote ecology and management. The Ohio State University Extension Bulletin 929, Columbus $\mathrm{OH}$.

Gese, E. M. 2001. Territorial defense by coyotes (Canis latrans) in Yellowstone National Park, Wyoming: Who, how, where, when, and why. Canadian Journal of Zoology 79:980-987.

Gese, E. M., and R. L. Ruff. 1997. Scent-marking by coyotes, Canis latrans: The influence of social and ecological factors. Animal Behaviour 54:1155-1166.

Golightly, R. T., and R. D. Ohmart. 1983. Metabolism and body temperature of two desert canids - coyotes and kit foxes. Journal of Mammalogy 64:624-635.

Gompper, M. E. 2002a. Top carnivores in the suburbs? Ecological and conservation issues raised by colonization of northeastern North America by coyotes.

Bioscience 52:185-190.

Gompper, M. E. 2002b. The ecology of northeast coyotes. WCS Working Paper No. 17:1-47.

Gosselink, T. E., T. R. Van Deelen, R. E. Warner, and M. G. Joselyn. 2003. Temporal habitat partitioning and spatial use of coyotes and red foxes in east-central Illinois. Journal of Wildlife Management 67:90-103. 
Grinder, M. I., and P. R. Krausman. 2001. Home range, habitat use, and nocturnal activity of coyotes in an urban environment. Journal of Wildlife Management 65:887-898.

Harrison, D. J., and J. R. Gilbert. 1985. Denning ecology and movements of coyotes in Maine during pup rearing. Journal of Mammalogy 66:712-719.

Harrison, D. J., and J. A. Harrison. 1984. Foods of adult Maine coyotes and their known aged pups. Journal of Wildlife Management 48:922-926.

Hill, E. P., P. W. Sumner, and J. B. Wooding. 1987. Human influences on range expansion of coyotes in the southeast. Wildlife Society Bulletin 15:521-524.

Johnson, D. H. 1980. The comparison of usage and availability measurements for evaluating resource preference. Ecology 61:65-71.

Kamler, J. F., W. B. Ballard, P. R. Lemons, R. L. Gilliland, and K. Mote. 2005. Home range and habitat use of coyotes in an area of native prairie, farmland and CRP fields. American Midland Naturalist 153:396-404.

Kamler, J. F., and P. S. Gipson. 2000. Space and habitat use by resident and transient coyotes. Canadian Journal of Zoology 78:2106-2111.

Karasov, W. H. 1992. Daily energy expenditure and the cost of activity in mammals. American Zoologist 32:238-248.

Keith, L. B., and S. E. M. Bloomer. 1993. Differential mortality of sympatric snowshoe hares and cottontail rabbits in central Wisconsin. Canadian Journal of Zoology 71:1694-1697.

Korschgen, L. J. 1957. Food habits of the coyote in Missouri. Journal of Wildlife Management 21:424-435.

Laundre, J. W., and L. Hernandez. 2003. Total energy budget and prey requirements of free-ranging coyotes in the Great Basin desert of the western United States. Journal of Arid Environments 55:675-689.

Leban, F. 1999. RSW Resource Selection for Windows.

Litvaitis, J. A., and W. W. Mautz. 1980. Food and energy use by captive coyotes. Journal of Wildlife Management 44:56-61.

Manly, B. F. J., L. L. McDonald, D. L. Thomas, T. L. McDonald, and W. P. Erickson. 2002. Resource Selection by Animals, Second Edition edition. Kluwer Academic Publishers, Norwell, MA. 
McCracken, J. G. 1982. Coyote foods in a southern California suburb. Wildlife Society Bulletin 10:280-281.

Morey, P. 2004. Landscape use and diet of coyotes, Canis latrans, in the Chicago metropolitan area. Masters Thesis. Utah State University, Logan.

O'Donoghue, M., S. Boutin, C. J. Krebs, D. L. Murray, and E. J. Hofer. 1998. Behavioural responses of coyotes and lynx to the snowshoe hare cycle. Oikos 82:169-183.

Openlands Project. 1999. Under pressure: Land consumption in the Chicago region, 1998-2028. Openland Project, Chicago IL.

Paine, C. R., J. D. Thompson, R. Montgomery, M. Cline, and B. D. Dugger. 2003. Status and management of Canada geese in northeastern Illinois. Final report W-131-R1 to R3, Illinois Department of Natural Resources.

Patterson, B. R., L. K. Benjamin, and F. Messier. 1998. Prey switching and feeding habits of eastern coyotes in relation to snowshoe hare and white-tailed deer densities. Canadian Journal of Zoology 76:1885-1897.

Patterson, B. R., S. Bondrup-Nielsen, and F. Messier. 1999. Activity patterns and daily movements of the eastern coyote, Canis latrans, in Nova Scotia. Canadian FieldNaturalist 113:251-257.

Patterson, B. R., and F. Messier. 2001. Social organization and space use of coyotes in eastern Canada relative to prey distribution and abundance. Journal of Mammalogy 82:463-477.

Quinn, T. 1997a. Coyote (Canis latrans) food habits in three urban habitat types of western Washington. Northwest Science 71:1-5.

Quinn, T. 1997b. Coyote (Canis latrans) habitat selection in urban areas of western Washington via analysis of routine movements. Northwest Science 71:289-297.

Randa, L. A., and J. A. Yunger. 2004. The influence of prey availability and vegetation characteristics on scent station visitation rates of coyotes, Canis latrans, in a heterogeneous environment. Canadian Field-Naturalist 118:341-353.

Riley, S. P. D., R. M. Sauvajot, T. K. Fuller, E. C. York, D. A. Kamradt, C. Bromley, and R. K. Wayne. 2003. Effects of urbanization and habitat fragmentation on bobcats and coyotes in southern California. Conservation Biology 17:566-576.

Rodgers, A. R., and A. P. Carr. 2002. ESRI ArcView Home Range Extension. in. Ontario Ministry of Natural Resources, Toronto, Ontario, Canada. 
Rosenblatt, D. L., E. J. Heske, S. L. Nelson, D. H. Barber, M. A. Miller, and B. MacAllister. 1999. Forest fragments in east-central Illinois: Islands or habitat patches for mammals? American Midland Naturalist 141:115-123.

Sargeant, A. B., M. A. Sovada, and R. J. Greenwood. 1998. Interpreting evidence of depredations of duck nests in the praitie pothole region. in. U.S. Geological Survey, Northern Prairie Wildlife Research Center, Jamestown, ND and Ducks Unlimited, Inc., Memphis TN. Jamestown, ND: Northern Prarie Wildlife Research Center Online. http://www.npwrc.usgs.gov/resource/birds/depred/depred.htm (version 02JUL99).

Servin, J., V. Sanchez-Cordero, and S. Gallina. 2003. Distances traveled daily by coyotes, Canis latrans, in a pine-oak forest in Durango, Mexico. Journal of Mammalogy 84:547-552.

Shargo, E. S. 1988. Home range, movements, and activity patterns of coyotes (Canis latrans) in Los Angeles suburbs. Ph.D. University of California Los Angeles, Los Angeles.

Shivik, J. A., and E. M. Gese. 2000. Territorial significance of home range estimators for coyotes. Wildlife Society Bulletin 28:940-946.

Smith, D. W., R. O. Peterson, and D. B. Houston. 2003. Yellowstone after wolves. Bioscience 53:330-340.

Sooter, C. A. 1946. Habits of coyotes in destroying nests and eggs of waterfowl. Journal of Wildlife Management 10:33-38.

Sperry, C. 1941. Food habits of the coyote. U.S. Department Interior Wildlife Research Bulletin 4:1-70.

Staller, E. L., W. E. Palmer, J. P. Carroll, R. P. Thornton, and D. C. Sisson. 2005. Identifying predators at northern bobwhite nests. Journal of Wildlife Management 69:124-132.

Stephens, D. W., and J. R. Krebs. 1981. Foraging theory. Princeton University Press, Princeton, New Jersey.

Sullivan, J. 2000. An atlas of biodiversity. Chicago Region Biodiversity Council, Chicago IL.

Swihart, R. K., Z. Feng, N. A. Slade, D. M. Mason, and T. M. Gehring. 2001. Effects of habitat destruction and resource supplementation in a predator-prey metapopulation model. Journal of Theoretical Biology 210:287-303 
Swihart, R. K., and R. H. Yahner. 1984. Winter use of insular habitat patches by the eastern cottontail. Acta Theriologica 29:45-56.

Tigas, L. A., D. H. Van Vuren, and R. M. Sauvajot. 2002. Behavioral responses of bobcats and coyotes to habitat fragmentation and corridors in an urban environment. Biological Conservation 108:299-306.

Tigas, L. A., D. H. Van Vuren, and R. M. Sauvajot. 2003. Carnivore persistence in fragmented habitats in urban southern California. Pacific Conservation Biology 9:144-151.

U.S. Census Bureau. 2000. Population Estimates Program, Washington D.C.

Vermeer, K. 1970. A study of Canada Geese, Branta canadensis, nesting on islands in southeastern Alberta. Canadian Journal of Zoology 48:235-240.

Wang, Y., and D. K. Moskovits. 2001. Tracking fragmentation of natural communities and changes in land cover: applications of landsat data for conservation in an urban landscape (Chicago Wilderness). Conservation Biology 15:835-843.

Way, J. G., I. M. Ortega, and E. G. Strauss. 2004. Movement and activity patterns of eastern coyotes in a coastal, suburban environment. Northeastern Naturalist 11:237-254.

White, G. C., and R. Garrot. 1990. Analysis of wildlife radio-tracking data. Academic Press, New York, New York, USA.

Windberg, L. A., S. M. Ebbert, and B. T. Kelly. 1997. Population characteristics of coyotes (Canis latrans) in the northern Chihuahuan Desert of New Mexico. American Midland Naturalist 138:197-207. 


\begin{tabular}{|c|c|}
\hline Habitat Type & Description \\
\hline Buffer & $\begin{array}{l}\text { This category includes lakes, rivers, streams, and wetlands } \\
\text { with a } 50 \mathrm{~m} \text { buffer surrounding edge of all water types. }\end{array}$ \\
\hline Urban-land & $\begin{array}{l}\text { Built-up and paved areas, including buildings, pavement, and } \\
\text { roads. }\end{array}$ \\
\hline Urban-grass & $\begin{array}{l}\text { Lawns, including golf courses, lawned parks and residential } \\
\text { yards. }\end{array}$ \\
\hline Agriculture & Areas where crops are cultivated \\
\hline Woodland & $\begin{array}{l}\text { This habitat includes forests and savannas with greater than } \\
10 \% \text { canopy coverage. }\end{array}$ \\
\hline Grassland & $\begin{array}{l}\text { This habitat is dominated by grasses with less than } 10 \% \text { tree } \\
\text { canopy cover. The dominant feature of this habitat is natural } \\
\text { prairie grasses and other grassy areas that do not meet urban- } \\
\text { grass requirements. }\end{array}$ \\
\hline
\end{tabular}

Table 2.1. Description of habitat types used to classify nesting habitat and analyze coyote habitat selection in the Chicago metropolitan area. Habitat types were reclassified from Chicago Wilderness Landsat habitat maps. 
Pre-nesting season $(n=12)$

Habitat Type

Habitat type Buffer Grassland Agriculture Woodland Urban-land Urban-grass Rank

\begin{tabular}{llllllll}
\hline Buffer & & +++ & + & $+*$ & +++ & +++ & 5 \\
Grassland & --- & & + & + & $+*$ & +++ & 4 \\
Agriculture & - & - & & - & + & +++ & 2 \\
Woodland $-*$ & - & + & & + & +++ & 3 \\
Urban-land & --- & $-*$ & - & - & & +++ & 1 \\
Urban-grass --- & --- & --- & --- & --- & & 0 \\
\hline
\end{tabular}

Nesting season $(n=12)$

Habitat Type

Habitat type Buffer Grassland Agriculture Woodland Urban-land Urban-grass Rank

\begin{tabular}{|c|c|c|c|c|c|c|c|}
\hline Buffer & & + & + & + & $\overline{+++}$ & ++++ & \\
\hline Grassland & - & & + & + & +++ & +++ & 4 \\
\hline Agriculture & - & - & & - & + & + & 2 \\
\hline Woodland & - & - & + & & + & $+*$ & 3 \\
\hline Urban-land & --- & --- & - & - & & + & 1 \\
\hline Urban-grass & --- & --- & - & $-*$ & - & & 0 \\
\hline
\end{tabular}

Table 2.2. Simplified ranking matrices for coyotes $(n=12)$ during goose pre-nesting and nesting seasons comparing the number of radio locations for each animal in each habitat type with the proportion of each habitat type within the animal's $95 \% \mathrm{MCP}$ home range. Each element in the matrix was replaced by its sign; a triple sign indicates significant deviation from random at $P<=0.05$; a $*$ sign indicates $0.05<P<0.10$. 
Nesting season $(n=19)$

Habitat Type

\begin{tabular}{|c|c|c|c|c|c|c|c|}
\hline Habitat type & $\overline{\text { Buff }}$ & r Grassland & Agriculture & Woodland & $\overline{\text { Urban-land }}$ & Urban-grass & Rank \\
\hline Buffer & & + & + & + & +++ & +++ & 5 \\
\hline Grassland & - & & + & + & +++ & +++ & 4 \\
\hline Agriculture & - & - & & - & + & $+^{*}$ & 2 \\
\hline Woodland & - & - & + & & +++ & +++ & 3 \\
\hline Urban-land & --- & --- & - & --- & & + & 1 \\
\hline Urban-grass & --- & --- & $-*$ & --- & - & & 0 \\
\hline
\end{tabular}

Post-nesting season $(n=19)$

Habitat Type

Habitat type Buffer Grassland Agriculture Woodland Urban-land Urban-grass Rank

\begin{tabular}{llllllll}
\hline Buffer & & - & + & - & +++ & +++ & 3 \\
Grassland + & & + & + & +++ & +++ & 5 \\
Agriculture - & - & & - & + & + & 2 \\
Woodland + & - & + & & +++ & +++ & 4 \\
Urban-land --- & --- & - & - & & + & 1 \\
Urban-grass --- & --- & - & --- & - & & 0 \\
\hline
\end{tabular}

Table 2.3. Simplified ranking matrices for coyotes $(n=19)$ during goose nesting and postnesting seasons comparing the number of radio locations for each animal in each habitat type with the proportion of each habitat type within the animal's 95\% MCP home range. Each mean element in the matrix was replaced by its sign; a triple sign indicates significant deviation from random at $P<=0.05 ; \mathrm{a} *$ sign indicates $0.05<P<0.10$. 


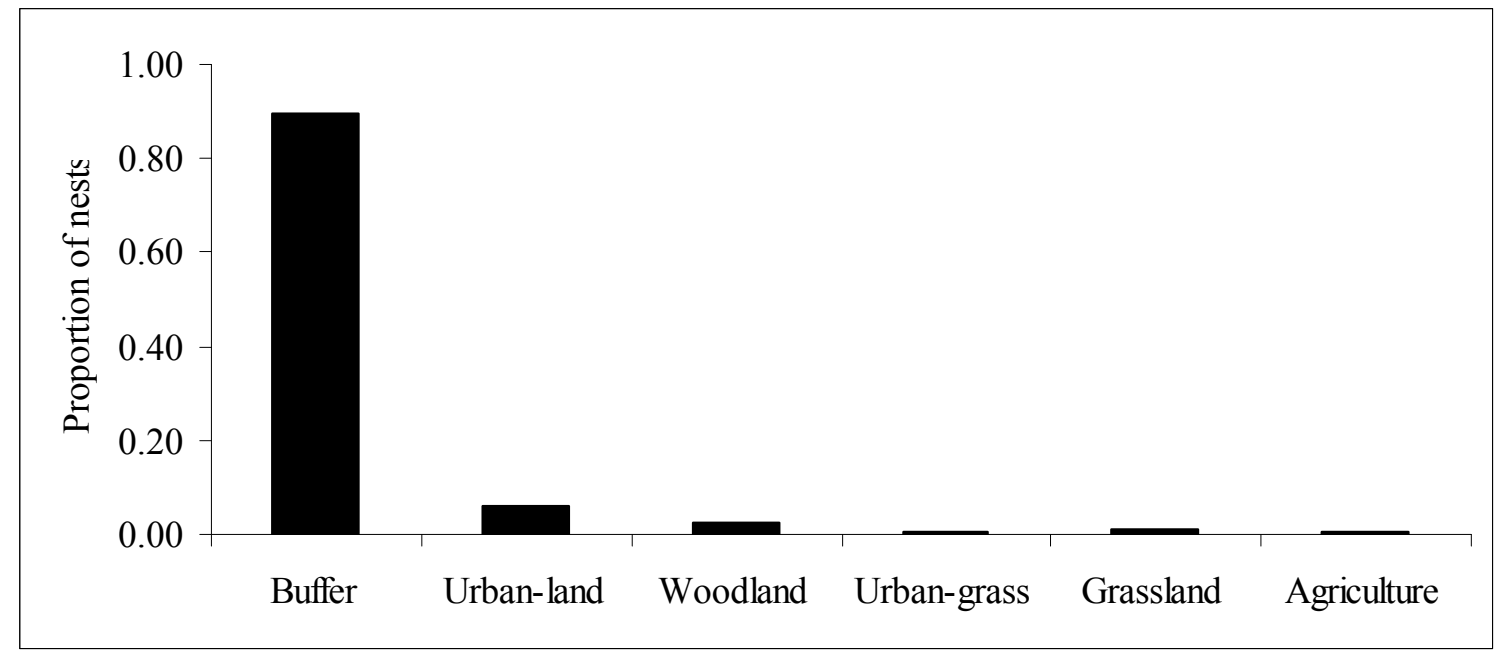

Figure 2.1. Proportion of Canada goose nests located by Cline (2004) pooled over all years within each habitat type in the Chicago region. 


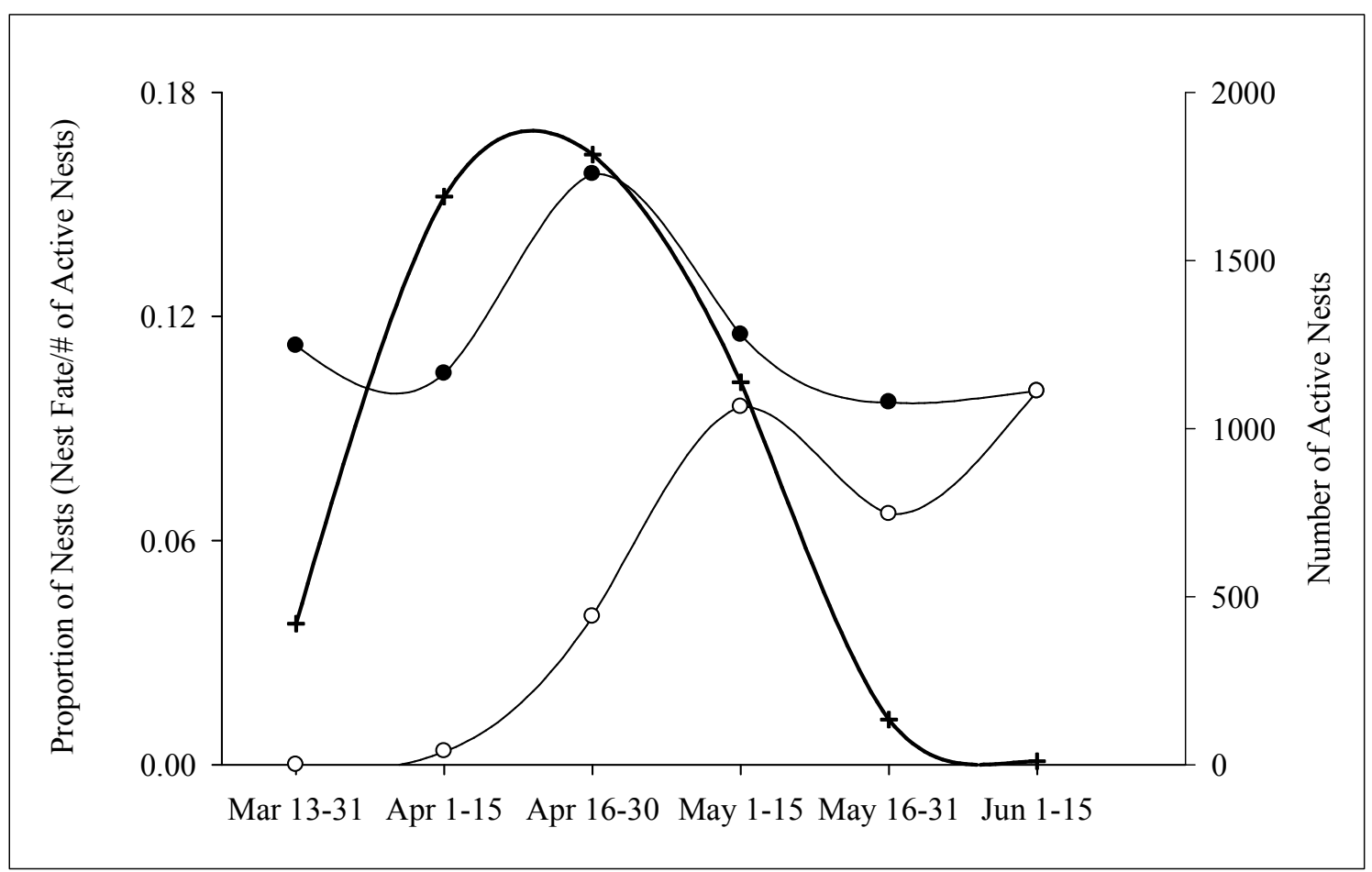

Figure 2.2. Number of nests pooled over all years for each fate (depredated and deserted) proportional to the number of active nests during the same time period within the Chicago metropolitan area. 


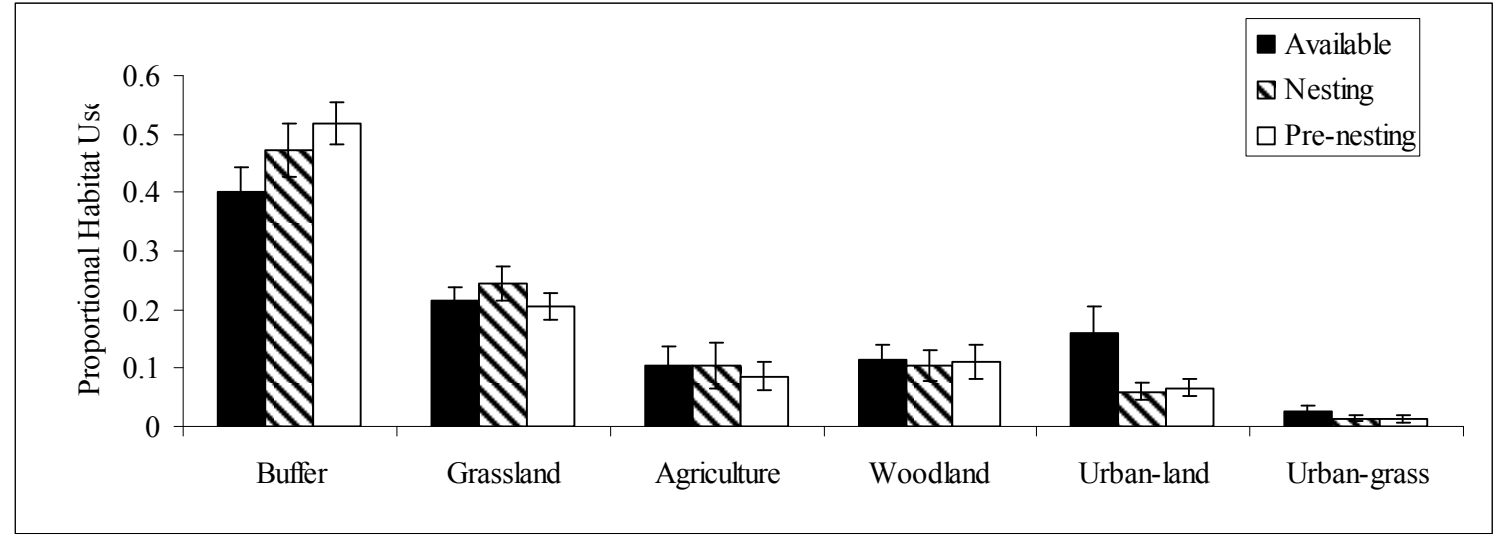

Figure 2.3. Coyote use $(n=12)$ and availability of each habitat type during pre-nesting and nesting seasons within the Chicago metropolitan area. 


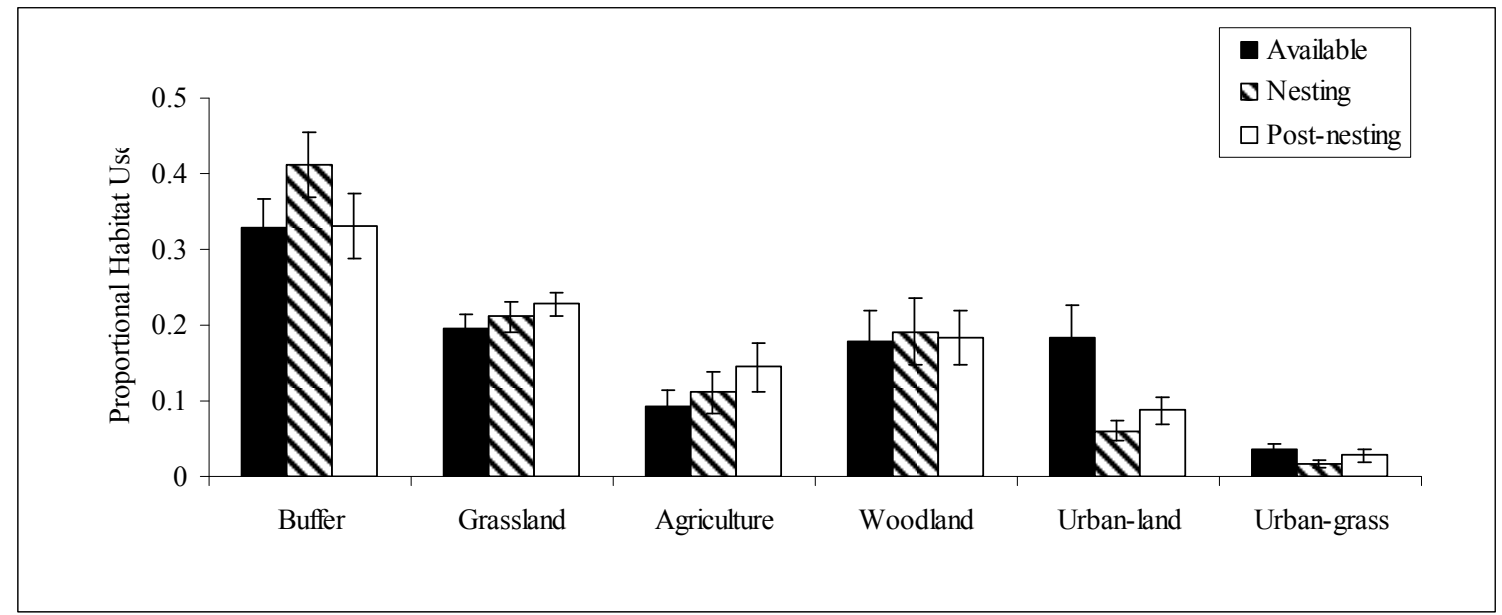

Figure 2.4. Coyote use $(n=19)$ and the availability of each habitat type during postnesting and nesting seasons within the Chicago metropolitan area. 


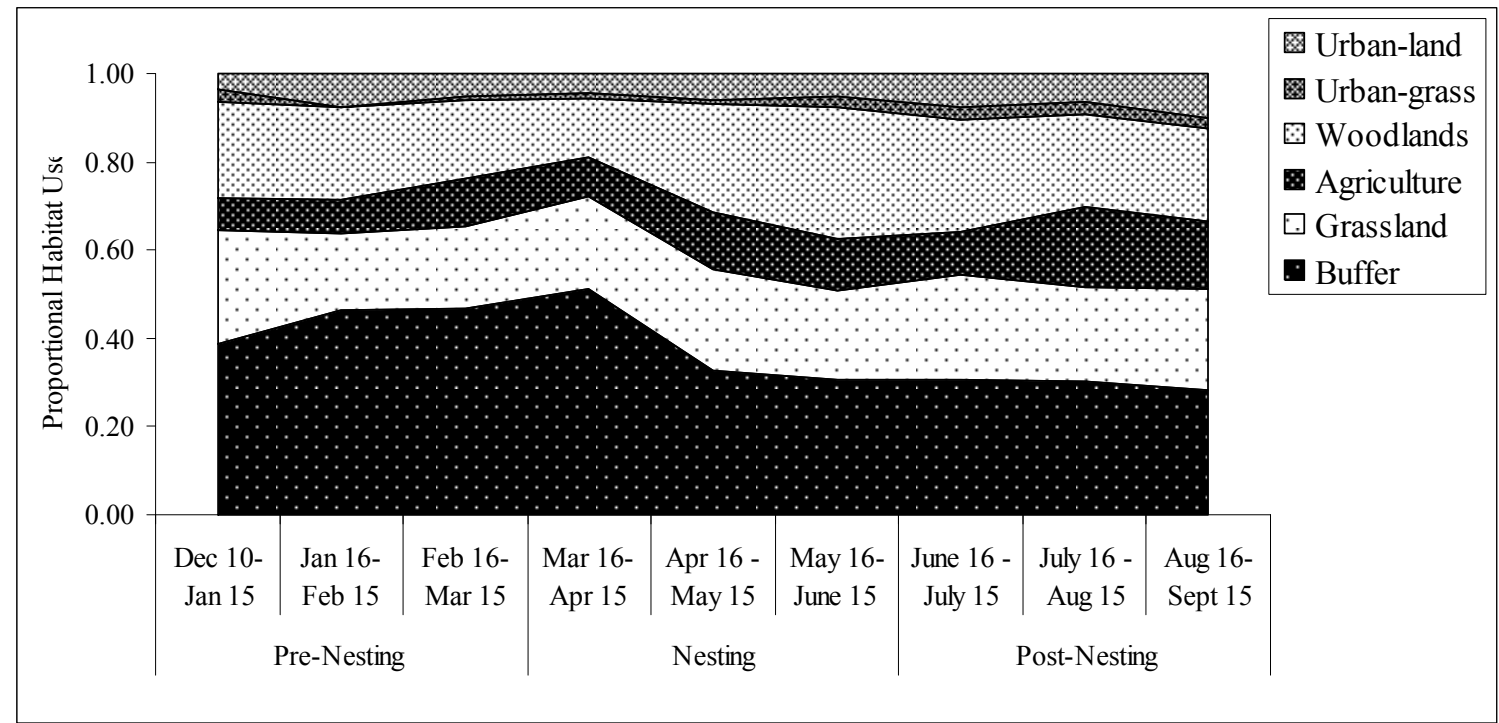

Figure 2.5. Monthly coyote habitat use for 6 habitat types starting at the beginning of the nesting season and continuing through the end of the post-nesting season in the Chicago metropolitan area. 


\section{CHAPTER 3}

\section{INFLUENCE OF URBAN COYOTES ON A RESIDENT CANADA GOOSE POPULATION}

\section{INTRODUCTION}

Wildlife species that were once associated with rural land and undeveloped wilderness are increasingly found in urbanized areas, producing wildlife communities that are distinct from those found in natural landscapes. It is important to study the influence of newly colonizing predators on existing prey species within these unique wildlife communities. Both high food availability and low harvest of predators within urban areas allow predator populations to exceed those found in more natural environments (Fedriani et al. 2001, Prange and Gehrt 2004). Increased abundance of certain predators in the urban environment may impact prey species differently than the normal predator densities found in rural and wilderness areas. Increased predator densities in urban areas likely influence the often overly abundant prey populations and, consequently, may relieve some nuisance problems faced by many cities.

Wildlife species that are capable of existing and flourishing in the urban environment must adapt and alter their behavior to deal with factors of urbanization. The urban environment provides high quality food sources to many urban wildlife species, as 
anthropogenic waste, seeds from bird feeders and road killed animals are consistently available (Forman and Alexander 1998, Kristan et al. 2004, Prange et al. 2004). Increased food availability allows predators to reduce their home range size (Fedriani et al. 2001, Atwood et al. 2004, Hidalgo-Mihart et al. 2004, Prange et al. 2004), causing them to spend more time per unit area within their home range. Small home range sizes may lead to an increase in predation on seasonally available food sources, which may not have been found within larger home ranges. Furthermore, the decrease in home range size is often associated with high predator densities, thus increasing the potential for a clumped, seasonally abundant prey to be found by either the coyote (Canis latrans) pack that defends the territory where the seasonal food source is available or by an intruding neighboring pack.

It is important to examine influences that urbanization has on the wildlife community and how increased predator presence is affecting urban prey populations. Urbanization affects predators and prey by causing changes in behavior or demographic parameters. Wildlife species, particularly carnivores, residing in urban areas are often forced to alter activity patterns to avoid periods of high human activity (Kitchen et al. 2000, McClennen et al. 2001), which could reduce the ability of predators to find and capture prey. Alternatively, prey species in urban areas may also shift their activity patterns to avoid human activity, thus increasing the overlap between the activity patterns of predator and prey, and increasing the opportunity for predators to encounter prey items.

Arrival of top-level predators into natural systems provides top-down control of prey populations that have only otherwise been influenced by bottom up factors and 
disease (Peterson 1999, Mech et al. 2001). In cases where prey populations are not selfregulating, top-down control is an important factor that can maintain prey populations at or below carrying capacity, thus reducing the potential for over grazing of food resources that can lead to widespread die-off (Marburger and Thomas 1965, Peterson 1999). This top-down influence may cause predator and prey populations to fluctuate based on predator abundance. Top-down control of prey populations has been primarily identified for specialist predator populations (Estes and Palmisano 1974, Peterson 1999), but the influence of generalist predators may have a large influence as well. Generalist predators are capable of utilizing alternative food sources, which may allow population levels to remain stable during periods when primary prey items are scarce or unavailable.

Presence of generalist predators can reduce the cyclic nature of prey populations due to the consistent predation by generalist predators (Hanski et al. 1991). Prey populations that are depredated by generalist predators may be slow to rebound after a population crash, due to the constant predation pressure with the presence of a generalist predator. Alternatively, generalist predators may undergo prey-switching at low prey densities allowing populations that reach low levels to rebound. Prey-switching may allow a low density prey population to rebound if the predator switches predation efforts to a competitor species (Murdoch 1969).

The presence of a newly occurring abundant top-level generalist predator, such as the coyote in the Chicago metropolitan area (Ambrose 1996, Gehrt 2003), may influence urban prey populations that have had little population regulation through either top-down or bottom-up factors. Due to the prevalence of high quality food resources in the urban environment, many prey populations have increased with little bottom up control 
(Ankney 1996, Boal and Mannan 1999, Etter et al. 2002, Prange and Gehrt 2004). Urban predators play an important role in the urban environment, as they may have the ability to control urban prey populations that have otherwise experienced little population control.

Canada goose (Branta canadensis) populations have thrived in urban locations because habitat alterations have changed inhospitable habitats into suitable goose habitat. Resident urban Canada goose populations are not likely limited by a bottom-up effect due to the availability of urban grass, a high quality food source (Smith et al. 1999), as well as the abundance of ponds, marshes and lakes. In addition, many predator populations were initially reduced or eliminated with encroaching urbanization, allowing urban prey species, such as Canada geese, to flourish in the absence of this top-down effect. Topdown control of urban prey species may be restored as predator populations in many urban environments have become reestablished, with some reaching higher densities in urbanized areas than rural areas (Fedriani et al. 2001, Crooks 2002, Gehrt 2004, Prange and Gehrt 2004). Coyote populations have increased in many urban locations and may provide top-down control of prey species that have exhibited high exponential growth in the absence of a relatively large predator.

My primary objective was to use empirical data to model the influence that coyotes have on an urban Canada goose population. My goal was to determine the maximum effect coyotes have on the Chicago Canada goose population by identifying the population growth rate in the absence of coyotes. 


\section{METHODS}

I created an age-classified Leslie matrix population model to identify the annual population growth rate $(\lambda)$ using MATLAB 7.3.0 (The MathWorks Inc.) The model was used to examine the potential influence coyotes have on the Chicago Canada goose population. I used published and unpublished data on fecundities and survival rates of Canada geese to build the model with the demographic parameters coming from a study conducted in the Chicago region (Paine et al. 2003, Cline 2004) and from similar studies in west central Illinois and Missouri (Lawrence 1986, Coluccy et al. 2003) (Table 3.1). Paine (2003) used banding and radio telemetry data to calculate survival rates for the Chicago metropolitan Canada goose flock. Survival estimates from banding data were calculated using MARK (White and Burnham 1999) by creating models that were based on comparison of after hatch year female birds vs. female birds that were banded in the study area and then recovered in the study area. Models were evaluated for goodness of fit using Akaike's information criterion (AIC). Nest success was estimated using the program MARK. The age-classified projection matrix,

$$
A=\left[\begin{array}{cccccc}
F_{1} & F_{2} & F_{3} & F_{4} & F_{5} & F_{6} \\
S_{1} & 0 & 0 & 0 & 0 & 0 \\
0 & S_{2} & 0 & 0 & 0 & 0 \\
0 & 0 & S_{3} & 0 & 0 & 0 \\
0 & 0 & 0 & S_{4} & 0 & 0 \\
0 & 0 & 0 & 0 & S_{5} & S_{6}
\end{array}\right] \text { and } N=\left[\begin{array}{c}
n_{1} \\
n_{2} \\
n_{3} \\
n_{4} \\
n_{5} \\
n_{6}
\end{array}\right]
$$


was comprised of elements for fecundity $\left[F_{i}=\right.$ (nest success) $x$ (female goslings per successful nest) $\mathrm{x}$ (gosling survival) $\mathrm{x}$ (age-specific nesting rate)] in the first row and survival $\left[S_{i}=\right.$ age-specific survival (juvenile, 2 - 6+ years of age)] on subsequent rows, for age class i. Using the projection matrix, variations in population size and age structure $(\mathrm{N})$ can be calculated between times $\mathrm{t}$ and $\mathrm{t}+1$ from the equation:

$$
N_{t+1}=A N_{t}
$$

The model was constructed using only the female portion of the population (assuming a 50:50 sex ratio) using a density independent model with a yearly time step. Stable age distribution $\left(\mathrm{W}_{\mathrm{A}}\right)$ for the population was calculated from the right eigenvector associated with the dominant eigenvalue $(\lambda)$. Reproductive value $\left(V_{A}\right)$ for individuals in each age group is the left eigenvector and gives the expected relative contribution of a female currently in a given age group to future population growth.

To examine the influence of coyotes on the Canada goose population I used information on nest desertion, nest predation, and predation of adult birds (from chapter 1 and unpublished data). Both nest success and adult survival were increased to quantify the maximum affect of coyotes on the Canada goose population growth rate. Nest success was increased by an amount equivalent to the proportion of nests depredated by coyotes and deserted because of coyote presence. Annual adult survival was increased for each age group an amount equivalent to the proportion of adult geese killed by coyotes. The proportion of depredated and deserted nests attributed to coyotes was $78 \%$ and $73 \%$, respectively. I assumed that coyotes were responsible for half $(9 \%)$ of all adult 
mortality (18\%) not associated with hunting or vehicle collision (Paine et al. 2003). To determine the maximum influence coyotes may have had on the Canada goose population, I conducted simulations reducing the coyote effect on all matrix vital rates $\left(\mathrm{r}_{\mathrm{i}}\right)$ to zero. Simulations were also conducted to evaluate the effect coyotes had through 1) nest success (both nest desertion and predation), 2) nest desertion, 3) nest predation, and 4) adult mortality.

A simple elasticity analysis was conducted to determine which vital rates $\left(\mathrm{r}_{\mathrm{i}}\right)$, including factors associated with coyote predation, were the most sensitive to a small change (1\%) causing the largest impact on the Canada goose population growth rate (Mills et al. 1999, Morris and Doak 2002). Elasticity, which is the effect of a proportional change in $r_{i}$ on $\lambda$, is measured on a relative scale making it the best option for comparing the contributions of different vital rates to the population growth rate. Vital rates with the highest elasticity have the largest potential impact on the population growth rate. Elasticity of each variable is calculated using the equation:

$$
E_{r_{i}}=\frac{r_{i}}{\lambda} \frac{\partial \lambda}{\partial r_{i}}
$$

and was conducted for every $r_{i}$ of the population projection matrix.

\section{RESULTS}

At base parameter values the model estimated $\lambda=1.055$ for the Chicago area Canada goose population. Assuming a 50:50 sex ratio, after 10 years the Canada goose population would increase to 34,228 individuals from a starting population of 20,000 
breeding adults estimated by Paine (2003) from aerial surveys. The removal of all coyote variables caused $\lambda$ to increase to 1.214 causing the population to reach 139,074 Canada geese over a 10 year time period from a starting population of 20,000 breeding adults (Figure 3.1). Coyotes had the largest impact on Canada geese through nest predation. The influence of coyotes through nest desertion and adult mortality were similar, but were less important than nest predation (Figure 3.2).

The base model estimated that the goose population consists of 30.5\% 1 year olds, $19.9 \% 2$ year olds, $12.3 \% 3$ year olds, $9.3 \% 4$ year olds, $7.0 \% 5$ year olds, and $21.0 \% 6+$ year olds. Individuals in age classes 3 and up contribute $>40 \%$ more too future population growth than individuals in age classes 1 and 2. The removal of all coyote influence caused a shift in age structure to a goose population dominated by young age classes, with $38.5 \%$ of the population belonging to the 1 year old age class and only $11.6 \%$ belonging to the $6+$ age class.

Elasticity analysis indicated that $\lambda$ was most sensitive to survival of the $6+$ age group followed by nest success, gosling survival, and female goslings per successful nest. Small changes in coyote parameters were less meaningful in determining population growth. Nest predation was the most sensitive of all coyote parameters (Table 3.2). Coyote-caused nest desertion and adult mortality were similar in their sensitivities to $\lambda$.

\section{DISCUSSION}

Coyotes potentially have a large impact on the goose population in urban landscapes. Previous work of Canada goose population ecology in the Chicago metropolitan area identified high nest predation rates causing low nest success, which 
limited population growth of Canada geese (Paine et al. 2003, Cline 2004). Coyotes were responsible for the low nest success as they were identified as the primary predator of goose nests in the Chicago area (Chapter 1). The population growth rate calculated by my base model was lower than rates published in other studies (Coluccy et al. 2003), but is similar to the growth seen for the Mississippi flyway giant Canada goose population (U.S. Fish and Wildlife Service 2006). The model was developed to determine the functional response of the Chicago metropolitan Canada goose population to coyote predation. The modeling demonstrated that coyotes were an important factor in the reduced population growth rate for Canada geese in the Chicago metropolitan area. My estimate of the coyote effect on Canada goose vital rates was conservative. For example, I did not include raccoon predation that may not have occurred without prior coyote predation (Chapter 1). It is also likely that coyotes killed ganders away from nesting locations, leading to nest desertions that could not be attributed to coyote activity (Ewaschuk and Boag 1972). Furthermore, coyotes were likely responsible for more than half $(9 \%)$ of all adult mortality not associated with hunting or vehicle collisions $(18 \%)$ (Paine et al. 2003). Coyotes were likely responsible for more than half of the adult mortality as only birds that had coyote sign near the goose carcass were counted as mortality caused by a coyote (Paine unpublished data). Additionally, I believe that the adult mortality was likely higher because out of 36 video monitored nests I recorded one goose killed by a coyote and on 2 separate incidences adult geese were consumed in the background (Chapter 1). Multiple dead geese were typically found on nesting islands when coyote presence was documented. 
Elasticity analysis indicated that changes in survival of the $6+$ age group was the most sensitive to $\lambda$ and thus changes in survival of this age class would have the largest effect on the population growth rate of any model variable. Although survival of the $6+$ age group was the most sensitive model parameter, the influence of coyotes on adult survival was the least sensitive of all coyote related variables, due to the low proportion of adult geese depredated in the model.

Coyotes exerted the greatest influence on the regional Canada goose population growth rate through nest predation. Nest predation could be even more significant on the local scale where nesting sites produced few to no offspring because of coyote predation. One site, with 4 years of data collected over a 5 year period, had less than $10 \%$ of all nests hatch primarily due to predation. The site dropped from a high of 44 nests to a low of 25 nests annually (unpublished data). These high nest predation sites may have been further impacted by predation on adult geese, possibly resulting in declining goose populations in certain areas. Population sinks may form when geese immigrate to sites where low nest success is coupled with adult predation.

Coyotes may not only affect goose population growth through direct predation, but may also influence goose populations through the avoidance of predation. The presence of predator species can affect the behavior of prey species, causing them to use lower quality habitat than what is available (Ripple and Beschta 2004), thus geese may not nest or graze in the highest quality areas due to the presence of coyotes. Presence of coyotes may cause Canada geese to select nesting locations where predation risks are minimized, such as planters in urban parking lots or small islands that are highly isolated from the mainland (Cline 2004, Zoellick et al. 2004). Absence of coyotes may allow 
geese to use islands that are less isolated and nest more frequently on lake shores, which would allow current goose populations to increase considerably before their populations are limited by density dependent nesting factors. Absence of density dependent nesting factors and the high quantity of urban grass would make it unlikely that the goose population would be hindered by any factors other than top-down factors.

Prior to this study, the potential impact of coyotes on an urban Canada goose population was unknown. Coyotes were identified as an important factor in controlling Canada goose populations and were the primary reason that the goose population in the Chicago metropolitan area likely had a lower population growth rate than those reported for other giant Canada goose populations (Conover 1998, Coluccy et al. 2003, Maccarone and Cope 2004). Modeling projections demonstrate that coyotes are not stopping positive growth of the Canada goose population in the Chicago metropolitan area, but are slowing the population growth. 


\section{LITERATURE CITED}

Ambrose, S. E. 1996. Undaunted courage: Meriwether Lewis, Thomas Jefferson, and the opening of the American West. Simon and Schuster, New York.

Ankney, C. D. 1996. An embarrassment of riches: Too many geese. Journal of Wildlife Management 60:217-223.

Atwood, T. C., H. P. Weeks, and T. M. Gehring. 2004. Spatial ecology of coyotes along a suburban-to-rural gradient. Journal of Wildlife Management 68:1000-1009.

Boal, C. W., and R. W. Mannan. 1999. Comparitive breeding ecology of Cooper's hawks in urban and exurban areas of southeastern Arizona. Journal of Wildlife Management 63:77-84.

Cline, M. 2004. Productivity of giant Canada geese (Branta canadensis maxima) in northeastern Illinois. Masters Thesis. Southern Illinois University of Carbondale, Carbondale.

Coluccy, J. M., D. Graeber, and R. Drobney. 2003. Population modeling for giant Canada geese and implications for management. in T. J. Moser, R. D. Lien, K. C.

VerCauteren, K. F. Abraham, D. E. Andersen, J. G. Bruggink, J. M. Coluccy, D. A. Graber, J. O. Leafloor, D. R. Luukkonen, and R. E. Trost, editors. Proceedings of the 2003 International Canada Goose Symposium, Madison, Wi. USA.

Conover, M. 1998. Reproductive biology of an urban population of Canada geese. Pages 67-70 in D. H. Rusch, M. D. Samuel., D. D. Humburg, and B. D. Sullivan, editors. Proceedings of the 1998 International Canada Goose Symposium, Milwaukee Wi.

Crooks, K. R. 2002. Relative sensitivities of mammalian carnivores to habitat fragmentation. Conservation Biology 16:488-502.

Estes, J. A., and J. F. Palmisano. 1974. Sea otters: Their role in structuring near shore communities. Science 185:1058-1060.

Etter, D. R., K. M. Hollis, T. R. Van Deelen, D. R. Ludwig, J. E. Chelsvig, C. L. Anchor, and R. E. Warner. 2002. Survival and movements of white-tailed deer in suburban Chicago, Illinois. Journal of Wildlife Management 66:500-510.

Ewaschuk, E., and D. A. Boag. 1972. Factors affecting hatching success of densely nesting Canada geese. Journal of Wildlife Management 36:1097-1106.

Fedriani, J. M., T. K. Fuller, and R. M. Sauvajot. 2001. Does availability of anthropogenic food enhance densities of omnivorous mammals? An example with coyotes in southern California. Ecography 24:325-331. 
Forman, R., and L. Alexander. 1998. Roads and their major ecological effects. Annual Review of Ecology and Systematics 29:207-231.

Gehrt, S. D. 2003. Coyote ecology in the Chicago region. Progress Report, The Ohio State University, Columbus.

Gehrt, S. D. 2004. Ecology and management of striped skunks, raccoons, and coyotes in urban landscapes. Island Press, Washington D.C.

Hanski, I., L. Hansson, and H. Henttonen. 1991. Specialist predators, generalist predators, and the microtine rodent cycle. The Journal of Animal Ecology 60:353367.

Hidalgo-Mihart, M. G., L. Cantu-Salazar, C. A. Lopez-Gonzalez, E. C. Fernandez, and A. Gonzalez-Romero. 2004. Effect of a landfill on the home range and group size of coyotes (Canis latrans) in a tropical deciduous forest. Journal of Zoology 263:55-63.

Kitchen, A. M., E. M. Gese, and E. R. Schauster. 2000. Changes in coyote activity patterns due to reduced exposure to human persecution. Canadian Journal of Zoology 78:853-857.

Kristan, W., III, W. Boarman, and J. Crayon. 2004. Diet composition of common ravens across the urban-wildland interface of the West Mojave Desert. Wildlife Society Bulletin 32:244-253.

Lawrence, J. S. 1986. Population ecology of giant Canada geese in west central Illinois. Ph.D. Southern Illinois University, Carbondale, Ill, USA.

Maccarone, A. D., and C. H. Cope. 2004. Recent trends in the winter population of Canada geese (Branta canadensis) in Wichita, Kansas: 1998-2003. Transactions of the Kansas Academy of Science 107:77-82.

Marburger, R. G., and J. W. Thomas. 1965. A die-off in white-tailed deer of the central mineral region of Texas. Journal of Wildlife Management 29:706-716.

McClennen, N., R. R. Wigglesworth, and S. H. Anderson. 2001. The effect of suburban and agricultural development on the activity patterns of coyotes (Canis latrans). American Midland Naturalist 146:27-36.

Mech, D. L., D. W. Smith, K. M. Murphy, and D. R. MacNulty. 2001. Winter severity and wolf predation on a formerly wolf-free elk herd. Journal of Wildlife Management 65:998-1003.

Mills, L. S., D. F. Doak, and M. Wisdom. 1999. The reliability of conservation actions based upon elasticities of matrix models. Conservation Biology 13:815-829. 
Morris, W., and D. Doak. 2002. Quantitative conservation biology. Sinauer Associates, Sunderland, Massachusetts.

Murdoch, W. W. 1969. Switching in general predators: Experiments on predator specificity and stability of prey populations. Ecological Monographs 39:335-354.

Paine, C. R., J. D. Thompson, R. Montgomery, M. Cline, and B. D. Dugger. 2003. Status and management of Canada geese in northeastern Illinois. Final report W-131-R1 to R3, Illinois Department of Natural Resources.

Peterson, R. O. 1999. Wolf-moose interaction on Isle Royale: The end of natural regulation? Ecological Applications 9:10-16.

Prange, S., and S. D. Gehrt. 2004. Changes in mesopredator-community structure in response to urbanization. Canadian Journal of Zoology 82:1804-1817.

Prange, S., S. D. Gehrt, and E. P. Wiggers. 2004. Influences of anthropogenic resources on raccoon (Procyon lotor) movements and spatial distribution. Journal of Mammalogy 85:483-490.

Ripple, W. J., and R. L. Beschta. 2004. Wolves and the ecology of fear: Can predation risk structure ecosystems? Bioscience 54:755-766.

Smith, A. E., S. R. Craven, and P. D. Curtis. 1999. Managing Canada geese in urban environments. in Jack Berryman Institute Publication 16, and Cornell University Cooperative Extension, Ithaca, NY.

U.S. Fish and Wildlife Service. 2006. Waterfowl population status. U.S. Department of the interior, Washington, D.C.

White, G. C., and K. P. Burnham. 1999. Program MARK: Survival estimation from populations of marked animals. Bird Study 46 Supplement:120-138.

Zoellick, B. W., H. M. Ulmschneider, B. S. Cade, and A. W. Stanley. 2004. Isolation of Snake River islands and mammalian predation of waterfowl nests. Journal of Wildlife Management 68:650-662. 


\begin{tabular}{|c|c|c|}
\hline Parameter & Estimate & Source \\
\hline Nest success & 0.435 & Cline 2004 \\
\hline Female goslings per nest & 2.32 & Paine et al. 2003 \\
\hline Gosling survival to fledge & 0.6 & $\begin{array}{c}\text { Lawrence } 1986 \text {, Coluccy et } \\
\text { al. } 2003\end{array}$ \\
\hline \multicolumn{3}{|l|}{ Age-specific nesting rates } \\
\hline $1 \mathrm{yr}$ & 0.039 & $\begin{array}{l}\text { Lawrence 1986, Coluccy et } \\
\text { al. } 2003 \text {, Paine et al. } 2003\end{array}$ \\
\hline $2 \mathrm{yr}$ & 0.336 & $\begin{array}{l}\text { Lawrence 1986, Coluccy et } \\
\text { al. } 2003 \text {, Paine et al. } 2003\end{array}$ \\
\hline $3 \mathrm{yr}$ & 0.71 & $\begin{array}{l}\text { Lawrence 1986, Coluccy et } \\
\text { al. } 2003 \text {, Paine et al. } 2003\end{array}$ \\
\hline $4 \mathrm{yr}$ & 0.93 & $\begin{array}{l}\text { Lawrence 1986, Coluccy et } \\
\text { al. } 2003 \text {, Paine et al. } 2003\end{array}$ \\
\hline $5 \mathrm{yr}$ & 0.975 & $\begin{array}{l}\text { Lawrence 1986, Coluccy et } \\
\text { al. } 2003 \text {, Paine et al. } 2003\end{array}$ \\
\hline $6 \mathrm{yr}$ & 1 & $\begin{array}{l}\text { Lawrence 1986, Coluccy et } \\
\text { al. } 2003 \text {, Paine et al. } 2003\end{array}$ \\
\hline \multicolumn{3}{|l|}{ Age-specific survival rates } \\
\hline $1 \mathrm{yr}$ & 0.689 & Paine et al. 2003 \\
\hline $2 \mathrm{yr}$ & 0.666 & Paine et al. 2003 \\
\hline $3 \mathrm{yr}$ & 0.793 & Paine et al. 2003 \\
\hline $4 \mathrm{yr}$ & 0.793 & Paine et al. 2003 \\
\hline $5 \mathrm{yr}$ & 0.793 & Paine et al. 2003 \\
\hline $6 \mathrm{yr}$ & 0.793 & Paine et al. 2003 \\
\hline Predation rate & 0.694 & Paine et al. 2003 \\
\hline $\begin{array}{l}\text { Proportion of nests } \\
\text { depredated by coyote }\end{array}$ & 0.78 & This study \\
\hline $\begin{array}{l}\text { Proportion of nests } \\
\text { depredated by raccoon }\end{array}$ & 0.22 & This study \\
\hline Desertion rate & 0.187 & Paine et al. 2003 \\
\hline $\begin{array}{l}\text { Proportion of deserted nests } \\
\text { caused by coyotes }\end{array}$ & 0.729 & This study \\
\hline $\begin{array}{l}\text { Proportion of adult } \\
\text { mortality caused by coyotes }\end{array}$ & 0.09 & Paine unpublished data \\
\hline
\end{tabular}

Table 3.1. Population parameters used to model the resident Canada goose population in the Chicago metropolitan area. 


\begin{tabular}{|c|c|c|c|c|c|}
\hline \multirow[b]{2}{*}{ Model Parameter } & \multicolumn{2}{|c|}{ Base } & \multicolumn{2}{|c|}{ Adjusted } & \multirow{2}{*}{$\begin{array}{l}\text { Elasticity } \\
\text { value* }\end{array}$} \\
\hline & Estimate & Lambda & Estimate & Lambda & \\
\hline Nest desertion & 0.1870 & 1.0552 & 0.1851 & 1.0557 & 0.0426 \\
\hline $\begin{array}{l}\text { Proportion of nest } \\
\text { desertion caused by }\end{array}$ & & & & & \\
\hline coyotes & 0.7290 & 1.0552 & 0.7217 & 1.0555 & 0.0311 \\
\hline Nest predation rate & 0.5940 & 1.0552 & 0.5881 & 1.0566 & 0.1351 \\
\hline $\begin{array}{l}\text { Proportion of nest } \\
\text { predation by coyotes }\end{array}$ & 0.7800 & 1.0552 & 0.7722 & 1.0563 & 0.1054 \\
\hline $\begin{array}{l}\text { Proportion of nest } \\
\text { predation by raccoons }\end{array}$ & 0.2200 & 1.0552 & 0.2178 & 1.0555 & 0.0298 \\
\hline Nest Success & 0.4350 & 1.0552 & 0.4307 & 1.0533 & 0.1763 \\
\hline $\begin{array}{l}\text { Gosling Survival } \\
\text { Proportion of geese } \\
\text { nesting }\end{array}$ & 0.6000 & 1.0552 & 0.5940 & 1.0533 & 0.1763 \\
\hline $1 \mathrm{yr}$ & 0.0390 & 1.0552 & 0.0386 & 1.0552 & 0.0039 \\
\hline $2 \mathrm{yr}$ & 0.3360 & 1.0552 & 0.3326 & 1.0550 & 0.0221 \\
\hline $3 \mathrm{yr}$ & 0.7100 & 1.0552 & 0.7029 & 1.0549 & 0.0290 \\
\hline $4 \mathrm{yr}$ & 0.9300 & 1.0552 & 0.9207 & 1.0549 & 0.0285 \\
\hline $5 \mathrm{yr}$ & 0.9750 & 1.0552 & 0.9653 & 1.0550 & 0.0225 \\
\hline $6 \mathrm{yr}$ & 1.0000 & 1.0552 & 0.9900 & 1.0545 & 0.0699 \\
\hline Fecundity & & & & & \\
\hline $1 \mathrm{yr}$ & 0.0236 & 1.0552 & 0.0234 & 1.0552 & 0.0039 \\
\hline $2 \mathrm{yr}$ & 0.2035 & 1.0552 & 0.2014 & 1.0550 & 0.0221 \\
\hline $3 \mathrm{yr}$ & 0.4299 & 1.0552 & 0.4256 & 1.0549 & 0.0290 \\
\hline $4 \mathrm{yr}$ & 0.5631 & 1.0552 & 0.5575 & 1.0549 & 0.0285 \\
\hline $5 \mathrm{yr}$ & 0.5904 & 1.0552 & 0.5845 & 1.0550 & 0.0225 \\
\hline $6 \mathrm{yr}$ & 0.6055 & 1.0552 & 0.5995 & 1.0545 & 0.0699 \\
\hline Annual survival & & & & & \\
\hline $1 \mathrm{yr}$ & 0.6890 & 1.0552 & 0.6821 & 1.0534 & 0.1724 \\
\hline $2 \mathrm{yr}$ & 0.6540 & 1.0552 & 0.6475 & 1.0536 & 0.1502 \\
\hline $3 \mathrm{yr}$ & 0.7930 & 1.0552 & 0.7851 & 1.0539 & 0.1212 \\
\hline $4 \mathrm{yr}$ & 0.7930 & 1.0552 & 0.7851 & 1.0542 & 0.0925 \\
\hline $5 \mathrm{yr}$ & 0.7930 & 1.0552 & 0.7851 & 1.0545 & 0.0699 \\
\hline $6 \mathrm{yr}$ & 0.7930 & 1.0552 & 0.7851 & 1.0530 & 0.2086 \\
\hline Female goslings per nest & 2.3200 & 1.0552 & 2.2968 & 1.0533 & 0.1763 \\
\hline $\begin{array}{l}\text { Adult mortality caused by } \\
\text { coyotes }\end{array}$ & 0.0900 & 1.0552 & 0.0891 & 1.0555 & 0.0257 \\
\hline
\end{tabular}

Table 3.2. Elasticity calculations for parameters from the Chicago metropolitan goose population model including coyote influence variables. 


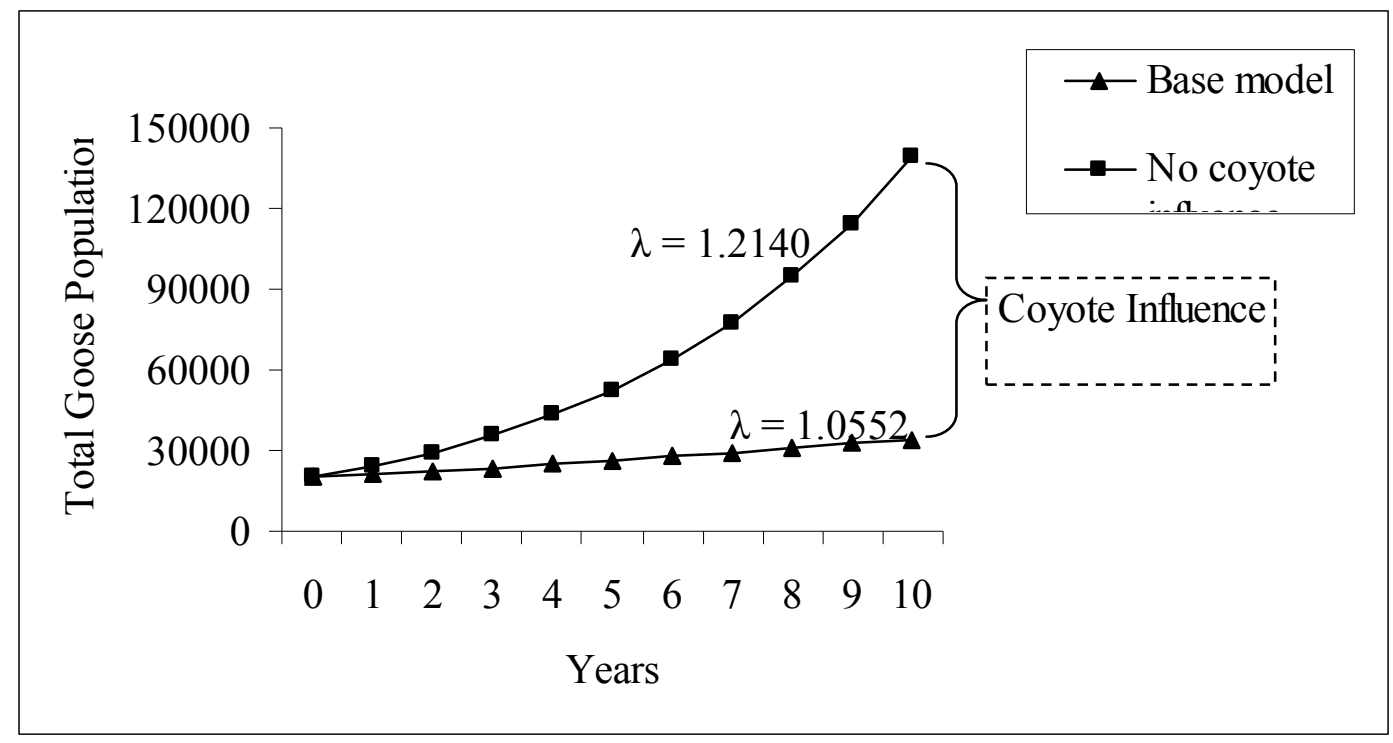

Figure 3.1. Population growth rate for the Chicago metropolitan Canada goose population and the estimated population growth rate with coyotes removed from the system. 


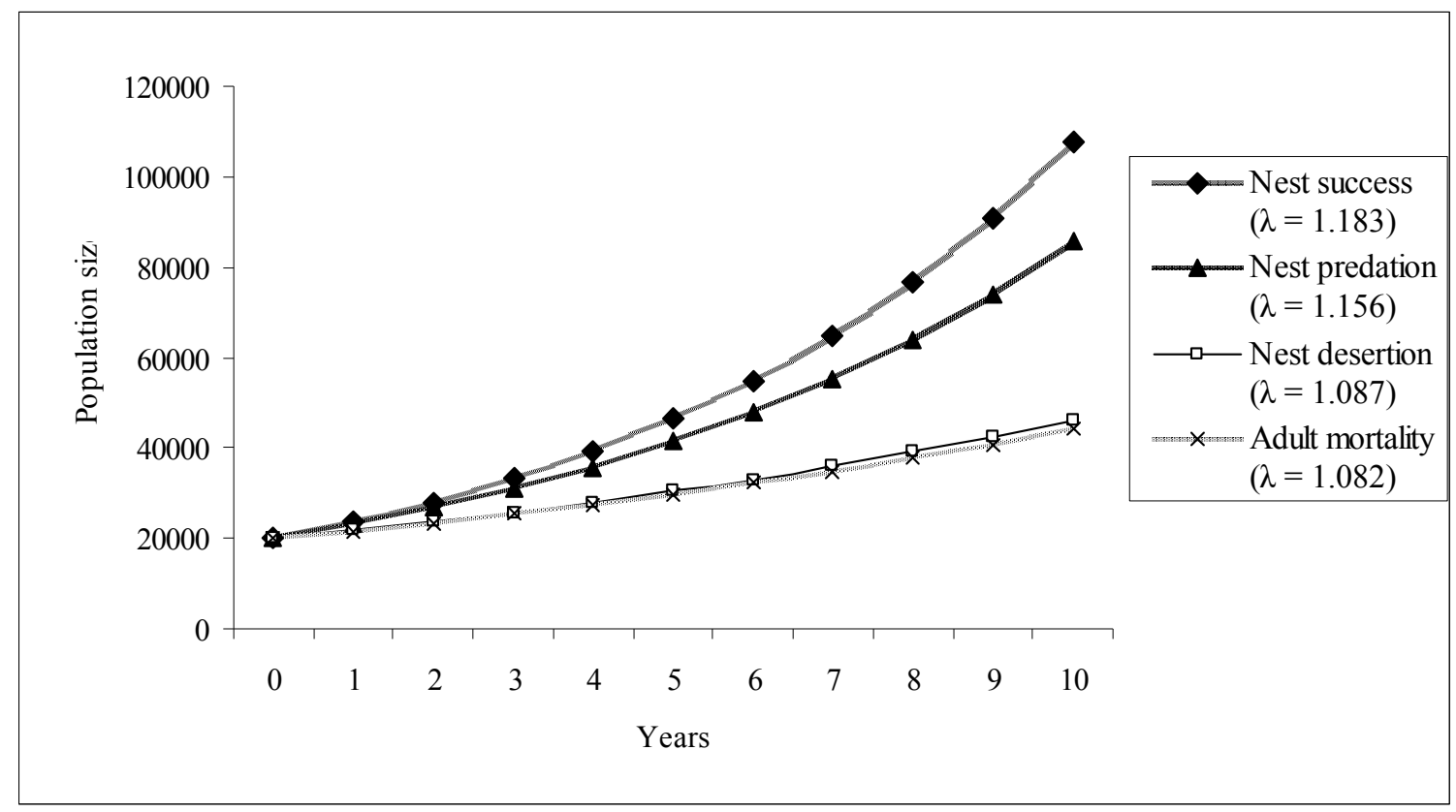

Figure 3.2. Population growth rates for the Canada goose population in the Chicago metropolitan area with coyote variables removed and model simulations conducted for each type of coyote influence. 


\section{BIBLIOGRAPHY}

Aebischer, N. J., P. A. Robertson, and R. E. Kenward. 1993. Compositional analysis of habitat use from animal radio tracking data. Ecology 74:1313-1325.

Aguilera, E., R. L. Knight, and J. L. Cummings. 1991. An evaluation of two hazing methods for urban Canada geese. Wildlife Society Bulletin 19:32-35.

Allan, J., J. Kirby, and C. Feare. 1995. The biology of Canada geese Branta canadensis in relation to the management of feral populations. Wildlife Biology 1:129-143.

Ambrose, S. E. 1996. Undaunted courage: Meriwether Lewis, Thomas Jefferson, and the opening of the American West. Simon and Schuster, New York.

Andelt, W. F., and S. H. Andelt. 1981. Habitat use by coyotes in southeastern Nebraska. Journal of Wildlife Management 45:1001-1005.

Ankney, C. D. 1996. An embarrassment of riches: Too many geese. Journal of Wildlife Management 60:217-223.

Anthony, R. M., J. B. Grand, T. F. Fondell, and B. F. J. Manly. 2004. A quantitative approach to identifying predators from nest remains. Journal of Field Ornithology 75:40-48

Anthony, R. M., J. B. Grand, T. F. Fondell, and D. A. Miller. 2006. Techniques for identifying predators of goose nests. Wildlife Biology 12:249-256.

Arjo, W. M., and D. H. Pletscher. 2004. Coyote and wolf habitat use in northwestern Montana. Northwest Science 78:24-32.

Atkinson, K. T., and D. M. Shackleton. 1991. Coyote, Canis latrans, ecology in a ruralurban environment. Canadian Field-Naturalist 105:49-54.

Atwood, T. C. 2006. The influence of habitat patch attributes on coyote group size and interaction in a fragmented landscape. Canadian Journal of Zoology 84:80-87.

Atwood, T. C., H. P. Weeks, and T. M. Gehring. 2004. Spatial ecology of coyotes along a suburban-to-rural gradient. Journal of Wildlife Management 68:1000-1009. 
Barrette, C., and F. Messier. 1980. Scent-marking in free-ranging coyotes, Canis latrans. Animal Behaviour 28:814-819.

Bekoff, M. 1977. Canis latrans. Mammalian Species 79:1-9.

Belant, J. L., T. W. Seamans, L. A. Tyson, and S. K. Ickes. 1996. Repellency of methyl anthranilate to pre-exposed and naive Canada geese. Journal of Wildlife Management 60:923-928.

Belant, J. L., L. A. Tyson, T. W. Seamans, and S. K. Ickes. 1997. Evaluation of lime as an avian feeding repellent. Journal of Wildlife Management 61:917-924.

Bety, J., and G. Gauthier. 2001. Effects of nest visits on predator activity and predation rate in a Greater Snow Goose colony. Journal of Field Ornithology 72:573-586.

Bingham, R. L., and L. A. Brennan. 2004. Comparison of type I error rates for statistical analyses of resource selection. Journal of Wildlife Management 68:206-212.

Blackwell, B. F., G. E. Bernhardt, and R. A. Dolbeer. 2002. Lasers as nonlethal avian repellents. Journal of Wildlife Management 66:250-258.

Blackwell, B. F., T. W. Seamans, and R. A. Dolbeer. 1999. Plant growth regulator (Stronghold (TM)) enhances repellency of anthraquinone formulation (Flight Conirol (TM)) to Canada geese. Journal of Wildlife Management 63:1336-1343.

Boal, C. W., and R. W. Mannan. 1999. Comparitive breeding ecology of Cooper's hawks in urban and exurban areas of southeastern Arizona. Journal of Wildlife Management 63:77-84.

Bolger, D. T. 2002. Habitat fragmentation effects on birds in southern California: Contrast to the top-down; paradigm. Studies in Avian Biology 25:141-157.

Bonner, B. M., W. Lutz, S. Jager, T. Redman, B. Reinhardt, U. Reichel, V. Krajewski, R. Weiss, J. Wissing, W. Knickmeier, W. H. Gerlich, U. C. Wend, and E. F. Kaleta. 2004. Do Canada geese (Branta canadensis Linnaeus, 1758) carry infectious agents for birds and man. European Journal of Wildlife Research 50:78-84.

Breiman, L., J. H. Friedman, R. A. Olshen, and C. J. Stone. 1984. Classification and regression trees. Chapman and Hall, New York, NY.

Brown, J. S., J. W. Laundre, and M. Gurung. 1999. The ecology of fear: Optimal foraging, game theory, and trophic interactions. Journal of Mammalogy 80:385399.

Brundige, G. 1993. Predation ecology of the eastern coyote, Canis latrans var., in the Adirondacks, New York. Ph.D. Dissertation. State University of New York, Syracuse, New York. 
Carey, C., H. Rahn, and P. Parisi. 1980. Calories, water, lipid and yolk in avian eggs. Condor 82:335-343.

Christens, E., H. Blokpoel, G. Rason, and S. W. D. Jarvie. 1995. Spraying white mineraloil on Canada goose eggs to prevent hatching. Wildlife Society Bulletin 23:228230.

Cline, M. 2004. Productivity of giant Canada geese (Branta canadensis maxima) in northeastern Illinois. Masters Thesis. Southern Illinois University of Carbondale, Carbondale.

Coluccy, J. M. 2001. Reproductive ecology, bioenergetics, and experimental removals of local giant Canada geese (Branta canadensis maxima) in central Missouri. Ph.D. University of Missouri, Columbia.

Coluccy, J. M., R. D. Drobney, D. A. Graber, S. L. Sheriff, and D. J. Witter. 2001. Attitudes of central Missouri residents toward local giant Canada geese and management alternatives. Wildlife Society Bulletin 29:116-123.

Coluccy, J. M., D. Graeber, and R. Drobney. 2003. Population modeling for giant Canada geese and implications for management. in T. J. Moser, R. D. Lien, K. C. VerCauteren, K. F. Abraham, D. E. Andersen, J. G. Bruggink, J. M. Coluccy, D. A. Graber, J. O. Leafloor, D. R. Luukkonen, and R. E. Trost, editors. Proceedings of the 2003 International Canada Goose Symposium, Madison, Wi. USA.

Conover, M. 1998. Reproductive biology of an urban population of Canada geese. Pages 67-70 in D. H. Rusch, M. D. Samuel., D. D. Humburg, and B. D. Sullivan, editors. Proceedings of the 1998 International Canada Goose Symposium, Milwaukee Wi.

Conover, M. R. 1991. Herbivory by Canada geese - diet selection and effect on lawns. Ecological Applications 1:231-236.

Conover, M. R., and G. G. Chasko. 1985. Nuisance Canada goose problems in the eastern United States. Wildlife Society Bulletin 13:228-233.

Conover, M. R., and G. S. Kania. 1991. Characteristics of feeding sites used by urbansuburban flocks of Canada geese in Connecticut. Wildlife Society Bulletin 19:3638.

Converse, K. A., and J. J. Kennelly. 1994. Evaluation of Canada goose sterilization for population-control. Wildlife Society Bulletin 22:265-269.

Cooper, J., and T. Keefe. 1997. Urban Canada goose management: policies and procedures. Transactions of the North American Wildlife and Natural Resources Conference 62:412-430. 
Crabtree, R. L., and J. W. Sheldon. 1999. Coyotes and canid coexistence in Yellowstone. Pages 127-163 in T. W. Clark, A. P. Curlee, S. C. Minta, and P. M. Kareiva, editors. Carnivores in Ecosystems: the Yellowstone Experience. Yale University Press, New Haven.

Crooks, K. R. 2002. Relative sensitivities of mammalian carnivores to habitat fragmentation. Conservation Biology 16:488-502.

Crooks, K. R., and M. E. Soule. 1999. Mesopredator release and avifaunal extinctions in a fragmented system. Nature 400:563-566.

Cypher, B. L. 1993. Food item use by coyote pups at Crab Orchard National Wildlife Refuge, Illinois. Transactions of the Illinois State Academy of Science 86:133137.

Cypher, B. L., K. A. Spencer, and J. H. Scrivner. 1996. Use of food items by sex and age classes of coyotes. California Fish and Game 82:42-47.

DeVault, T. L., M. B. Douglas, J. S. Castrale, C. E. Mills, T. Hayes, and O. E. Rhodes. 2005. Identification of nest predators at a least tern colony in southwestern Indiana. Waterbirds 28:445-449.

Estes, J. A., and J. F. Palmisano. 1974. Sea otters: Their role in structuring near shore communities. Science 185:1058-1060.

Etter, D. R., K. M. Hollis, T. R. Van Deelen, D. R. Ludwig, J. E. Chelsvig, C. L. Anchor, and R. E. Warner. 2002. Survival and movements of white-tailed deer in suburban Chicago, Illinois. Journal of Wildlife Management 66:500-510.

Ewaschuk, E., and D. A. Boag. 1972. Factors affecting hatching success of densely nesting Canada geese. Journal of Wildlife Management 36:1097-1106.

Fedriani, J. M., T. K. Fuller, and R. M. Sauvajot. 2001. Does availability of anthropogenic food enhance densities of omnivorous mammals? An example with coyotes in southern California. Ecography 24:325-331.

Fichter, E., G. Schildman, and J. H. Sather. 1955. Some feeding patterns of coyotes in Nebraska. Ecological Monographs 25:1-37.

Fitzner, R. E., and W. H. Rickard. 1983. Canada goose nesting performance along the Hanford reach of the Columbia River, 1971-1981. Northwest Science 57:267-272.

Forman, R., and L. Alexander. 1998. Roads and their major ecological effects. Annual Review of Ecology and Systematics 29:207-231.

Gehrt, S. D. 2003. Coyote ecology in the Chicago region. Progress Report, The Ohio State University, Columbus. 
Gehrt, S. D. 2004. Ecology and management of striped skunks, raccoons, and coyotes in urban landscapes. Island Press, Washington D.C.

Gehrt, S. D. 2006. Urban coyote ecology and management. The Ohio State University Extension Bulletin 929, Columbus OH.

Gehrt, S. D., and S. Prange. 2007. Interference competition between coyotes and raccoons: A test of the mesopredator release hypothesis. Behavioral Ecology 18:204-214.

Gese, E. M. 2001. Territorial defense by coyotes (Canis latrans) in Yellowstone National Park, Wyoming: Who, how, where, when, and why. Canadian Journal of Zoology 79:980-987.

Gese, E. M., and R. L. Ruff. 1997. Scent-marking by coyotes, Canis latrans: The influence of social and ecological factors. Animal Behaviour 54:1155-1166.

Gibeau, M. 1993. Use of urban habitats by coyotes in the vicinity of Banff, Alberta. Masters Thesis. University of Montana.

Golightly, R. T., and R. D. Ohmart. 1983. Metabolism and body temperature of two desert canids - coyotes and kit foxes. Journal of Mammalogy 64:624-635.

Gompper, M. E. 2002a. Top carnivores in the suburbs? Ecological and conservation issues raised by colonization of northeastern North America by coyotes. Bioscience 52:185-190.

Gompper, M. E. 2002b. The ecology of northeast coyotes. WCS Working Paper No. 17:1-47.

Gosselink, T. E., T. R. Van Deelen, R. E. Warner, and M. G. Joselyn. 2003. Temporal habitat partitioning and spatial use of coyotes and red foxes in east-central Illinois. Journal of Wildlife Management 67:90-103.

Grinder, M. I., and P. R. Krausman. 2001. Home range, habitat use, and nocturnal activity of coyotes in an urban environment. Journal of Wildlife Management 65:887-898.

Hanski, I., L. Hansson, and H. Henttonen. 1991. Specialist predators, generalist predators, and the microtine rodent cycle. The Journal of Animal Ecology 60:353367.

Hanson, H. C. 1965. The giant Canada goose. Carbondale: Southern Illinois University Publisher.

Hanson, W. C., and L. L. Eberhardt. 1971. A Columbia River Canada goose population, 1950-1970. Wildlife Monographs 28:1-56. 
Harrison, D. J., and J. R. Gilbert. 1985. Denning ecology and movements of coyotes in Maine during pup rearing. Journal of Mammalogy 66:712-719.

Harrison, D. J., and J. A. Harrison. 1984. Foods of adult Maine coyotes and their known aged pups. Journal of Wildlife Management 48:922-926.

Heinrich, J. W., and S. R. Craven. 1990. Evaluation of 3 damage abatement techniques for Canada geese. Wildlife Society Bulletin 18:405-410.

Heusmann, H. W. 1999. Special hunting seasons and resident Canada goose populations. Wildlife Society Bulletin 27:456-464.

Hidalgo-Mihart, M. G., L. Cantu-Salazar, C. A. Lopez-Gonzalez, E. C. Fernandez, and A. Gonzalez-Romero. 2004. Effect of a landfill on the home range and group size of coyotes (Canis latrans) in a tropical deciduous forest. Journal of Zoology 263:55-63.

Hill, E. P., P. W. Sumner, and J. B. Wooding. 1987. Human influences on range expansion of coyotes in the southeast. Wildlife Society Bulletin 15:521-524.

Hilley, J. D. 1976. Productivity of a resident giant Canada goose flock in northeastern South Dakota. Masters Thesis. South Dakota State University.

Johnson, D. H. 1980. The comparison of usage and availability measurements for evaluating resource preference. Ecology 61:65-71.

Johnson, D. H., A. B. Sargeant, and R. J. Greenwood. 1989. Importance of individual species of predators in nesting success of ducks in the Canadian Prairie Pothole Region. Canadian Journal of Zoology 67:291-297.

Kamler, J. F., W. B. Ballard, P. R. Lemons, R. L. Gilliland, and K. Mote. 2005. Home range and habitat use of coyotes in an area of native prairie, farmland and CRP fields. American Midland Naturalist 153:396-404.

Kamler, J. F., and P. S. Gipson. 2000. Space and habitat use by resident and transient coyotes. Canadian Journal of Zoology 78:2106-2111.

Karasov, W. H. 1992. Daily energy expenditure and the cost of activity in mammals. American Zoologist 32:238-248.

Keith, L. B., and S. E. M. Bloomer. 1993. Differential mortality of sympatric snowshoe hares and cottontail rabbits in central Wisconsin. Canadian Journal of Zoology 71:1694-1697.

Kitchen, A. M., E. M. Gese, and E. R. Schauster. 2000. Changes in coyote activity patterns due to reduced exposure to human persecution. Canadian Journal of Zoology 78:853-857. 
Klopman, R. K. 1958. The nesting of the Canada goose at Dog Lake, Manitoba. Wilson Bulletin 70:168-183.

Korschgen, L. J. 1957. Food habits of the coyote in Missouri. Journal of Wildlife Management 21:424-435.

Kristan, W., III, W. Boarman, and J. Crayon. 2004. Diet composition of common ravens across the urban-wildland interface of the West Mojave Desert. Wildlife Society Bulletin 32:244-253.

Kullas, H., M. Coles, J. Rhyan, and L. Clark. 2002. Prevalence of Escherichia coli serogroups and human virulence in faeces of urban Canada geese (Branta canadensis). International Journal of Environmental Health Research 12:153-162.

Laundre, J. W., and L. Hernandez. 2003. Total energy budget and prey requirements of free-ranging coyotes in the Great Basin desert of the western United States. Journal of Arid Environments 55:675-689.

Lawrence, J. S. 1986. Population ecology of giant Canada geese in west central Illinois. $\mathrm{Ph}$.D. Southern Illinois University, Carbondale, Ill, USA.

Leban, F. 1999. RSW Resource Selection for Windows.

Litvaitis, J. A., and W. W. Mautz. 1980. Food and energy use by captive coyotes. Journal of Wildlife Management 44:56-61.

Maccarone, A. D., and C. H. Cope. 2004. Recent trends in the winter population of Canada geese (Branta canadensis) in Wichita, Kansas: 1998-2003. Transactions of the Kansas Academy of Science 107:77-82.

Macdonald, D. W. 1983. The ecology of carnivore social-behavior. Nature 301:379-384.

Manly, B. F. J., L. L. McDonald, D. L. Thomas, T. L. McDonald, and W. P. Erickson. 2002. Resource Selection by Animals, Second Edition edition. Kluwer Academic Publishers, Norwell, MA.

Marburger, R. G., and J. W. Thomas. 1965. A die-off in white-tailed deer of the central mineral region of Texas. Journal of Wildlife Management 29:706-716.

McClennen, N., R. R. Wigglesworth, and S. H. Anderson. 2001. The effect of suburban and agricultural development on the activity patterns of coyotes (Canis latrans). American Midland Naturalist 146:27-36.

McCracken, J. G. 1982. Coyote foods in a southern California suburb. Wildlife Society Bulletin 10:280-281. 
Mech, D. L., D. W. Smith, K. M. Murphy, and D. R. MacNulty. 2001. Winter severity and wolf predation on a formerly wolf-free elk herd. Journal of Wildlife Management 65:998-1003.

Mezquida, E. T., S. J. Slater, and C. W. Benkman. 2006. Sage-Grouse and indirect interactions: Potential implications of coyote control on Sage-Grouse populations. Condor 108:747-759.

Miller, C. A., L. K. Campbell, and J. A. Yeagle. 2001. Attitudes of homeowners in the greater Chicago metropolitan region toward nuisance wildlife. SR-00-02, Illinois Natural History Survey, Champaign, IL.

Mills, L. S., D. F. Doak, and M. Wisdom. 1999. The reliability of conservation actions based upon elasticities of matrix models. Conservation Biology 13:815-829.

Morey, P. 2004. Landscape use and diet of coyotes, Canis latrans, in the Chicago metropolitan area. Masters Thesis. Utah State University, Logan.

Morris, W., and D. Doak. 2002. Quantitative conservation biology. Sinauer Associates, Sunderland, Massachusetts.

Murdoch, W. W. 1969. Switching in general predators: Experiments on predator specificity and stability of prey populations. Ecological Monographs 39:335-354.

O'Donoghue, M., S. Boutin, C. J. Krebs, D. L. Murray, and E. J. Hofer. 1998. Behavioural responses of coyotes and lynx to the snowshoe hare cycle. Oikos 82:169-183.

Openlands Project. 1999. Under pressure: Land consumption in the Chicago region, 1998-2028. Openland Project, Chicago IL.

Owen, M., J. Kirby, and D. Salmon. 1998. Canada geese in Great Britain: History, problems, and prospects. Pages 497-505 in D. H. Rusch, M. D. Samuel., D. D. Humburg, and B. D. Sullivan, editors. Proceedings International Goose Symposium, Milwaukee Wi.

Paine, C. R., J. D. Thompson, R. Montgomery, M. Cline, and B. D. Dugger. 2003. Status and management of Canada geese in northeastern Illinois. Final report W-131-R1 to R3, Illinois Department of Natural Resources.

Pasitschniakarts, M., and F. Messier. 1995. Predator Identification at simulated waterfowl nests using inconspicuous hair catchers and wax-filled eggs. Canadian Journal of Zoology 73:984-990.

Patterson, B. R., L. K. Benjamin, and F. Messier. 1998. Prey switching and feeding habits of eastern coyotes in relation to snowshoe hare and white-tailed deer densities. Canadian Journal of Zoology 76:1885-1897. 
Patterson, B. R., S. Bondrup-Nielsen, and F. Messier. 1999. Activity patterns and daily movements of the eastern coyote, Canis latrans, in Nova Scotia. Canadian FieldNaturalist 113:251-257.

Patterson, B. R., and F. Messier. 2001. Social organization and space use of coyotes in eastern Canada relative to prey distribution and abundance. Journal of Mammalogy 82:463-477.

Peterson, R. O. 1999. Wolf-moose interaction on Isle Royale: The end of natural regulation? Ecological Applications 9:10-16.

Pietz, P. J., and D. A. Granfors. 2000. Identifying predators and fates of grassland passerine nests using miniature video cameras. Journal of Wildlife Management 64:71-87.

Prange, S., and S. D. Gehrt. 2004. Changes in mesopredator-community structure in response to urbanization. Canadian Journal of Zoology 82:1804-1817.

Prange, S., S. D. Gehrt, and E. P. Wiggers. 2004. Influences of anthropogenic resources on raccoon (Procyon lotor) movements and spatial distribution. Journal of Mammalogy 85:483-490.

Quinn, T. 1995. Using public sighting information to investigate coyote use of urban habitat. Journal of Wildlife Management 59:238-245.

Quinn, T. 1997a. Coyote (Canis latrans) food habits in three urban habitat types of western Washington. Northwest Science 71:1-5.

Quinn, T. 1997b. Coyote (Canis latrans) habitat selection in urban areas of western Washington via analysis of routine movements. Northwest Science 71:289-297.

Rader, M. J., T. W. Teinert, L. A. Brennan, F. Hernandez, N. J. Silvy, and X. B. Wu. 2007. Identifying predators and nest fates of bobwhites in southern Texas. Journal of Wildlife Management 71:1626-1630.

Randa, L. A., and J. A. Yunger. 2004. The influence of prey availability and vegetation characteristics on scent station visitation rates of coyotes, Canis latrans, in a heterogeneous environment. Canadian Field-Naturalist 118:341-353.

Rickard, W. H., W. C. Hanson, and R. E. Fitzner. 1982. The non-fisheries biological resources of the Hanford reach of the Columbia River. Northwest Science 56:6276.

Riley, S. P. D., R. M. Sauvajot, T. K. Fuller, E. C. York, D. A. Kamradt, C. Bromley, and R. K. Wayne. 2003. Effects of urbanization and habitat fragmentation on bobcats and coyotes in southern California. Conservation Biology 17:566-576. 
Ripple, W. J., and R. L. Beschta. 2004. Wolves and the ecology of fear: Can predation risk structure ecosystems? Bioscience 54:755-766.

Rodgers, A. R., and A. P. Carr. 2002. ESRI ArcView Home Range Extension. in. Ontario Ministry of Natural Resources, Toronto, Ontario, Canada.

Rogers, C. M., and M. J. Caro. 1998. Song sparrows, top carnivores and nest predation: A test of the mesopredator release hypothesis. Oecologia (Berlin) 116:227-233.

Rosenblatt, D. L., E. J. Heske, S. L. Nelson, D. H. Barber, M. A. Miller, and B. MacAllister. 1999. Forest fragments in east-central Illinois: Islands or habitat patches for mammals? American Midland Naturalist 141:115-123.

Sabine, J. B., S. H. Schweitzer, and J. M. Meyers. 2006. Nest fate and productivity of American oystercatchers, Cumberland Island National Seashore, Georgia. Waterbirds 29:308-314.

Sargeant, A. B. 1972. Red fox spatial characteristics in relation to waterfowl predation. Journal of Wildlife Management 36:225-236.

Sargeant, A. B., M. A. Sovada, and R. J. Greenwood. 1998. Interpreting evidence of depredations of duck nests in the praitie pothole region. in. U.S. Geological Survey, Northern Prairie Wildlife Research Center, Jamestown, ND and Ducks Unlimited, Inc., Memphis TN. Jamestown, ND: Northern Prarie Wildlife Research Center Online. http://www.npwrc.usgs.gov/resource/birds/depred/depred.htm (version 02JUL99).

Schmidt, K. A. 2003. Nest predation and population declines in Illinois songbirds: A case for mesopredator effects. Conservation Biology 17:1141-1150.

Sequin, E. S., M. M. Jaeger, P. F. Brussard, and R. H. Barrett. 2003. Wariness of coyotes to camera traps relative to social status and territory boundaries. Canadian Journal of Zoology 81:2015-2025.

Servin, J., V. Sanchez-Cordero, and S. Gallina. 2003. Distances traveled daily by coyotes, Canis latrans, in a pine-oak forest in Durango, Mexico. Journal of Mammalogy 84:547-552.

Shargo, E. S. 1988. Home range, movements, and activity patterns of coyotes (Canis latrans) in Los Angeles suburbs. Ph.D. University of California Los Angeles, Los Angeles.

Shih, Y. S. 2003. Quest User Manual. Department of Mathematics National Chung Cheng University, Taiwan.

Shivik, J. A., and E. M. Gese. 2000. Territorial significance of home range estimators for coyotes. Wildlife Society Bulletin 28:940-946. 
Smith, A. E., S. R. Craven, and P. D. Curtis. 1999. Managing Canada geese in urban environments. in Jack Berryman Institute Publication 16, and Cornell University Cooperative Extension, Ithaca, NY.

Smith, D. W., R. O. Peterson, and D. B. Houston. 2003. Yellowstone after wolves. Bioscience 53:330-340.

Sooter, C. A. 1946. Habits of coyotes in destroying nests and eggs of waterfowl. Journal of Wildlife Management 10:33-38.

Soule, M. E., D. T. Bolger, A. C. Alberts, J. Wright, M. Sorice, and S. Hill. 1988. Reconstructed dynamics of rapid extinctions of chaparral-requiring birds in urban habitat islands. Conservation Biology 2:75-92.

Sovada, M. A., A. B. Sargeant, and J. W. Grier. 1995. Differential effects of coyotes and red foxes on duck nest success. Journal of Wildlife Management 59:1-9.

Sperry, C. 1941. Food habits of the coyote. U.S. Department Interior Wildlife Research Bulletin 4:1-70.

Staller, E. L., W. E. Palmer, J. P. Carroll, R. P. Thornton, and D. C. Sisson. 2005. Identifying predators at northern bobwhite nests. Journal of Wildlife Management 69:124-132.

Stephens, D. W., and J. R. Krebs. 1981. Foraging theory. Princeton University Press, Princeton, New Jersey.

Sullivan, J. 2000. An atlas of biodiversity. Chicago Region Biodiversity Council, Chicago IL.

Swihart, R. K., Z. Feng, N. A. Slade, D. M. Mason, and T. M. Gehring. 2001. Effects of habitat destruction and resource supplementation in a predator-prey metapopulation model. Journal of Theoretical Biology 210:287-303

Swihart, R. K., and R. H. Yahner. 1984. Winter use of insular habitat patches by the eastern cottontail. Acta Theriologica 29:45-56.

Thompson, F. R., and D. E. Burhans. 2004. Differences in predators of artificial and real songbird nests: Evidence of bias in artificial nest studies. Conservation Biology 18:373-380.

Thompson, F. R., W. Dijak, and D. E. Burbans. 1999. Video identification of predators at songbird nests in old fields. Auk 116:259-264. 
Tigas, L. A., D. H. Van Vuren, and R. M. Sauvajot. 2002. Behavioral responses of bobcats and coyotes to habitat fragmentation and corridors in an urban environment. Biological Conservation 108:299-306.

Tigas, L. A., D. H. Van Vuren, and R. M. Sauvajot. 2003. Carnivore persistence in fragmented habitats in urban southern California. Pacific Conservation Biology 9:144-151.

U.S. Census Bureau. 2000. Population Estimates Program, Washington D.C.

U.S. Fish and Wildlife Service. 2006. Waterfowl population status. U.S. Department of the interior, Washington, D.C.

VerCauteren, K. C., M. M. McLachlan, and M. J. Pipas. 2003. Nicarbazin-treated feed for reducing reproductive success of penned Canada geese. in T. J. Moser, R. D. Lien, K. C. VerCauteren, K. F. Abraham, D. E. Andersen, J. G. Bruggink, J. M. Coluccy, D. A. Graber, J. O. Leafloor, D. R. Luukkonen, and R. E. Trost, editors. Proceedings of the 2003 International Canada Goose Symposium, Madison, Wi.

Vermeer, K. 1970. A study of Canada Geese, Branta canadensis, nesting on islands in southeastern Alberta. Canadian Journal of Zoology 48:235-240.

Wang, Y., and D. K. Moskovits. 2001. Tracking fragmentation of natural communities and changes in land cover: applications of landsat data for conservation in an urban landscape (Chicago Wilderness). Conservation Biology 15:835-843.

Way, J. G., I. M. Ortega, and E. G. Strauss. 2004. Movement and activity patterns of eastern coyotes in a coastal, suburban environment. Northeastern Naturalist 11:237-254.

Werner, S. J., and L. Clark. 2006. Effectiveness of a motion-activated laser hazing system for repelling captive Canada geese. Wildlife Society Bulletin 34:2-7.

White, G. C., and K. P. Burnham. 1999. Program MARK: Survival estimation from populations of marked animals. Bird Study 46 Supplement:120-138.

White, G. C., and R. Garrot. 1990. Analysis of wildlife radio-tracking data. Academic Press, New York, New York, USA.

Windberg, L. A., S. M. Ebbert, and B. T. Kelly. 1997. Population characteristics of coyotes (Canis latrans) in the northern Chihuahuan Desert of New Mexico. American Midland Naturalist 138:197-207.

Zoellick, B. W., H. M. Ulmschneider, B. S. Cade, and A. W. Stanley. 2004. Isolation of Snake River islands and mammalian predation of waterfowl nests. Journal of Wildlife Management 68:650-662. 
APPENDIX A. QUALITATIVE SIGN COLLECTED FROM DEPREDATED CANADA GOOSE NESTS 


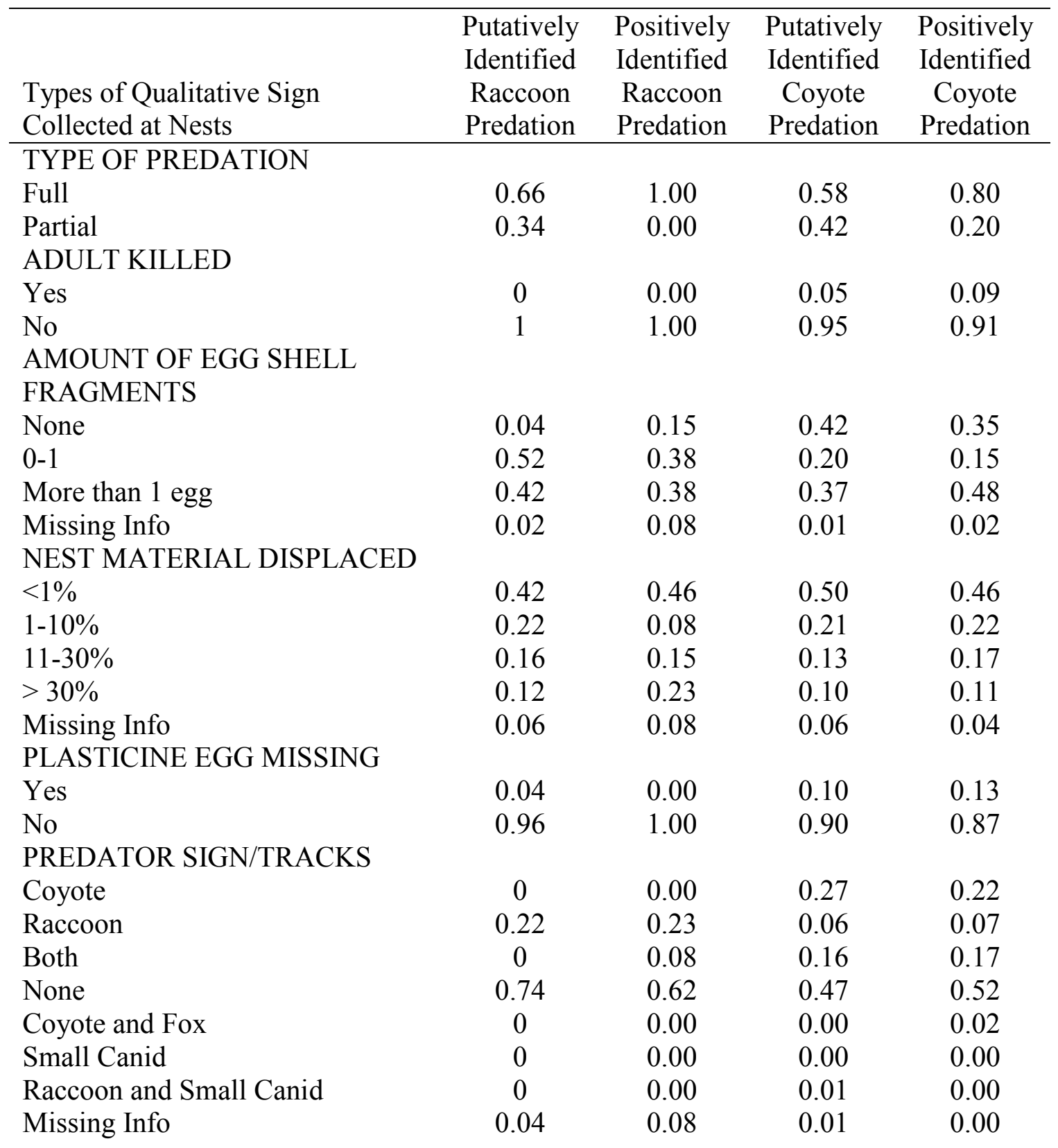

Appendix A. Qualitative sign collected from nests where the predator species was putatively identified through sign at nest or positively identified through video or dentition in plasticine eggs. 
Appendix A. Cont'd

DISTANCE OF EGGS

Proportion of nests with eggs

$>=5 \mathrm{~m}$ away from nest

0.26

0.23

0.31

0.52

Proportion of nests with eggs

$>=1 \mathrm{~m}$ away from nest

0.6

0.69

0.46

0.41

All eggs found and $<5 \mathrm{~m}$ away

0.74

0.62

0.10

0.11 
APPENDIX B. QUANTITATIVE SIGN COLLECTED FROM DEPREDATED CANADA GOOSE NESTS 
$95 \% \mathrm{CI}$

Quantitative sign collected at depredated nests Mean SE Min Max Lower Upper

PUTATIVELY IDENTIFIED RACCOON DEPREDATION

Number of cached egg

Number of eggs with small holes or

cracked

Number of eggs with large holes

Number of egg shells trampled

Number with side opening

Number with top/bottom opening

Number of eggs with $>25 \%$ of contents

Number of eggs $>=5 \mathrm{~m}$ away

Number of eggs $<5$ m away

Number of eggs $>=1 \mathrm{~m}$ away

Number of eggs missing

Number of eggs depredated

POSITIVELY IDENTIFIED RACCOON DEPREDATION

Number of cached egg

Number of eggs with small holes or

cracked

Number of eggs with large holes

Number of egg shells trampled

Number with side opening

Number with top/bottom opening

Number of eggs with $>25 \%$ of contents

Number of eggs $>=5 \mathrm{~m}$ away

Number of eggs $<5$ m away

Number of eggs $>=1 \mathrm{~m}$ away

Number of eggs missing

Number of eggs depredated

$\begin{array}{cccccc}0.04 & 0.04 & 0.00 & 2.00 & -0.04 & 0.12 \\ & & & & & \\ 0.32 & 0.24 & 0.00 & 12.00 & -0.17 & 0.81 \\ 0.86 & 0.14 & 0.00 & 4.00 & 0.58 & 1.14 \\ 0.74 & 0.19 & 0.00 & 7.00 & 0.36 & 1.12 \\ 0.62 & 0.14 & 0.00 & 4.00 & 0.35 & 0.89 \\ 0.10 & 0.05 & 0.00 & 2.00 & 0.00 & 0.20 \\ 0.00 & 0.00 & 0.00 & 0.00 & 0.00 & 0.00 \\ 0.50 & 0.15 & 0.00 & 4.00 & 0.21 & 0.79 \\ 1.52 & 0.23 & 0.00 & 7.00 & 1.06 & 1.98 \\ 1.26 & 0.23 & 0.00 & 7.00 & 0.80 & 1.72 \\ 0.00 & 0.00 & 0.00 & 0.00 & 0.00 & 0.00 \\ 2.02 & 0.23 & 1.00 & 7.00 & 1.56 & 2.48 \\ & & & & & \\ & & & & & \\ 0.00 & 0.00 & 0.00 & 0.00 & 0.00 & 0.00 \\ & & & & & \\ 0.00 & 0.00 & 0.00 & 0.00 & 0.00 & 0.00 \\ 1.15 & 0.30 & 0.00 & 3.00 & 0.51 & 1.80 \\ 0.85 & 0.53 & 0.00 & 7.00 & -0.31 & 2.00 \\ 0.54 & 0.24 & 0.00 & 2.00 & 0.01 & 1.07 \\ 0.31 & 0.13 & 0.00 & 1.00 & 0.02 & 0.60 \\ 0.00 & 0.00 & 0.00 & 0.00 & 0.00 & 0.00 \\ 0.38 & 0.21 & 0.00 & 2.00 & -0.08 & 0.85 \\ 1.62 & 0.54 & 0.00 & 7.00 & 0.44 & 2.79 \\ 1.54 & 0.55 & 0.00 & 7.00 & 0.34 & 2.74 \\ 0.23 & 0.12 & 0.00 & 1.00 & -0.03 & 0.50 \\ 2.23 & 0.53 & 1.00 & 7.00 & 1.07 & 3.39\end{array}$

Appendix B. Quantitative sign collected from nests where the predator species was putatively identified through sign at nest or positively identified using either infrared video equipment or dentition in plasticine eggs. 
Appendix B. Cont'd

\begin{tabular}{|c|c|c|c|c|c|c|}
\hline \multirow{2}{*}{ Quantitative sign collected at nests } & \multirow[b]{2}{*}{ Mean } & \multirow[b]{2}{*}{ SE } & \multirow[b]{2}{*}{ Min } & \multirow[b]{2}{*}{ Max } & \multicolumn{2}{|c|}{$95 \% \mathrm{CI}$} \\
\hline & & & & & Lower & Upper \\
\hline \multirow{2}{*}{\multicolumn{7}{|c|}{$\begin{array}{l}\text { PUTATIVELY IDENTIFIED COYOTE } \\
\text { DEPREDATION }\end{array}$}} \\
\hline & & & & & & \\
\hline \multirow{2}{*}{\multicolumn{7}{|c|}{ Number of eggs with small holes or }} \\
\hline & & & & & & \\
\hline Number of eggs with large holes & 0.66 & 0.08 & 0.00 & 7.00 & 0.51 & 0.82 \\
\hline Numb & 0.29 & 0.05 & 0.00 & .00 & 0.19 & 0.38 \\
\hline Numb & 0.47 & 0.06 & 0.00 & 5.00 & 0.34 & 0.60 \\
\hline Numbe & 0.14 & 0.04 & 0.00 & 5.00 & 0.07 & 0.21 \\
\hline Num & & & & & 0.22 & 0.44 \\
\hline Nur & & 0.07 & 0 & 6. & .38 & 0.64 \\
\hline & & 0.10 & 0.00 & $7 .($ & 0.72 & 1.10 \\
\hline Numb & 2 & 0.09 & 0.00 & 7.00 & 0.75 & 1.10 \\
\hline Numl & 1.47 & 0.10 & 0.00 & 9.00 & 1.29 & 1.66 \\
\hline Numb & .92 & 0.14 & 1.00 & 13.00 & 2.65 & 3.19 \\
\hline \multicolumn{7}{|l|}{ POSITIVELY IDENTIFIED COYOTE } \\
\hline DEPREDATIO & & & & & & \\
\hline Number of cached egg & 0.24 & 0.12 & 0.00 & 4.00 & 0.00 & 0.48 \\
\hline $\begin{array}{l}\text { Number of eggs with small holes or } \\
\text { cracked }\end{array}$ & & & & & -0.03 & 0.16 \\
\hline 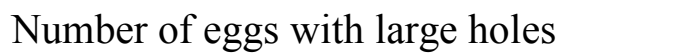 & & 0.18 & 0.00 & 4.00 & 0.51 & 1.23 \\
\hline Numb & 0.37 & 0.12 & 0.00 & 4.00 & 0.13 & 0.61 \\
\hline & & 0.18 & 0.00 & 4.00 & 0.43 & 1.14 \\
\hline & 00 & 0.05 & 00 & $20+2-3$ & -0.02 & 0.19 \\
\hline & 0.3 & 0.11 & 0.00 & 3.00 & 0.08 & 0.53 \\
\hline $\mathrm{Nur}$ & 0.85 & 0.20 & 0.00 & 5.00 & 0.45 & 1.24 \\
\hline $\operatorname{ggs}<5 \mathrm{~m}$ away & 0.85 & 0.17 & 0.00 & 4.00 & 0.51 & 1.18 \\
\hline Num & 10 & 0.24 & 0.00 & 6.00 & 0.90 & 1.88 \\
\hline & 1.5 & 0.25 & 0.00 & 9.00 & 1.00 & 2.00 \\
\hline Number of eggs depredated & 3.24 & 0.32 & 1.00 & 13.00 & 2.58 & 3.89 \\
\hline
\end{tabular}


APPENDIX C. MAP RECLASSIFICATION FOR 164 HABITAT AND LANDUSE TYPES 


\begin{tabular}{|c|c|c|}
\hline $\begin{array}{c}\text { ID } \\
\text { Number }\end{array}$ & Class Names & $\begin{array}{c}\text { Habitat } \\
\text { Classification }\end{array}$ \\
\hline 0 & Undefined area around the map) & \\
\hline 1 & Native woody/Residential & Woodland \\
\hline 2 & Savanna/Residential & Woodland \\
\hline 3 & Prairie/Residential & Grassland \\
\hline 4 & Wetland/Residential & Buffer \\
\hline 5 & Unassociated grassy/Residential & Grassland \\
\hline 6 & Unassociated woody/Residential & Woodland \\
\hline 7 & Water/Residential & Buffer \\
\hline 8 & Native woody/Commercial & Woodland \\
\hline 9 & Savanna/Commercial & Woodland \\
\hline 10 & Prairie/Commercial & Grassland \\
\hline 11 & Wetland/Commerial & Buffer \\
\hline 12 & Unassociated grassy/Commercial & Grassland \\
\hline 13 & Unassociated woody/Commercial & Woodland \\
\hline 14 & Water/Commercial & Buffer \\
\hline 15 & Native woody/Office campus & Woodland \\
\hline 16 & Savanna/Office campus & Woodland \\
\hline 17 & Prairie/Office campus & Grassland \\
\hline 18 & Wetland/Office campus & Buffer \\
\hline 19 & Unassociated grassy/Office campus & Grassland \\
\hline 20 & Unassociated woody/Office campus & Woodland \\
\hline 21 & Water/Office campus & Buffer \\
\hline 22 & Native woody/Culture & Woodland \\
\hline 23 & Savanna/Culture & Woodland \\
\hline 24 & Prairie/Culture & Grassland \\
\hline 25 & Wetland/Culture & Buffer \\
\hline 26 & Unassociated grassy/Culture & Grassland \\
\hline 27 & Unassociated woody/Culture & Woodland \\
\hline 28 & Water/Culture & Buffer \\
\hline 29 & Native woody/Institutional & Woodland \\
\hline 30 & Savanna/Institutional & Woodland \\
\hline
\end{tabular}

Appendix C. Reclassification of 164 habitat from Chicago Wilderness and NASA Landsat Thematic Mapper images with $28.5 \mathrm{~m}$ resolution to 6 habitat types used for resource selection analysis and to identify goose nesting habitat. 
Appendix C. Cont'd

\begin{tabular}{|c|c|c|}
\hline ID & & $\begin{array}{c}\text { Habitat } \\
\text { Classification }\end{array}$ \\
\hline Number & Class Names & Classification \\
\hline 31 & Prairie/Institutional & Grassland \\
\hline 32 & Wetland/Institutional & Buffer \\
\hline 33 & Unassociated grassy/Institutional & Grassland \\
\hline 34 & Unassociated woody/Institutional & Woodland \\
\hline 35 & Water/Institutional & Buffer \\
\hline 36 & Native woody/Inst. Open space & Woodland \\
\hline 37 & Savanna/Inst. Open space & Woodland \\
\hline 38 & Prairie/Inst. Open space & Grassland \\
\hline 39 & Wetland/Inst. Open space & Buffer \\
\hline 40 & Unassociated grassy/Inst. Open space & Grassland \\
\hline 41 & Unassociated woody/Inst. Open space & Woodland \\
\hline 42 & Water/Inst. Open space & Buffer \\
\hline 43 & Native woody/Governmental & Woodland \\
\hline 44 & Savanna/Governmental & Woodland \\
\hline 45 & Prairie/Governmental & Grassland \\
\hline 46 & Wetland/Governmental & Buffer \\
\hline 47 & Unassociated grassy/Governmental & Grassland \\
\hline 48 & Unassociated woody/Governmental & Woodland \\
\hline 49 & Water/Governmental & Buffer \\
\hline 50 & Native woody/Prison & Woodland \\
\hline 51 & Savanna/Prison & Woodland \\
\hline 52 & Prairie/Prison & Grassland \\
\hline 53 & Wetland/Prison & Buffer \\
\hline 54 & Unassociated grassy/Prison & Grassland \\
\hline 55 & Unassociated woody/Prison & Woodland \\
\hline 56 & Water/Prison & Buffer \\
\hline 57 & Native woody/Cemetery & Woodland \\
\hline 58 & Savanna/Cemetery & Woodland \\
\hline 59 & Prairie/Cemetery & Grassland \\
\hline 60 & Wetland/Cemetery & Buffer \\
\hline 61 & Unassociated grassy/Cemetery & Grassland \\
\hline 62 & Unassociated woody/Cemetery & Woodland \\
\hline 63 & Water/Cemetery & Buffer \\
\hline 64 & Native woody/Industrial & Woodland \\
\hline 65 & Savanna/Industrial & Woodland \\
\hline 66 & Prairie/Industrial & Grassland \\
\hline
\end{tabular}


Appendix C. Cont'd

\begin{tabular}{|c|c|c|}
\hline $\begin{array}{c}\text { ID } \\
\text { Number }\end{array}$ & Class Names & $\begin{array}{c}\text { Habitat } \\
\text { Classification }\end{array}$ \\
\hline 67 & Wetland/Industrial & Buffer \\
\hline 68 & Unassociated grassy/Industrial & Grassland \\
\hline 69 & Unassociated woody/Industrial & Woodland \\
\hline 70 & Water/Industrial & Buffer \\
\hline 71 & Native woody/Indust. park & Woodland \\
\hline 72 & Savanna/Indust. park & Woodland \\
\hline 73 & Prairie/Indust. park & Grassland \\
\hline 74 & Wetland/Indust. park & Buffer \\
\hline 75 & Unassociated grassy/Indust. park & Grassland \\
\hline 76 & Unassociated woody/Indust. park & Woodland \\
\hline 77 & Water/Indust. park & Buffer \\
\hline 78 & Native woody/Interstate toll & Woodland \\
\hline 79 & Savanna/Interstate toll & Woodland \\
\hline 80 & Prairie/Interstate toll & Grassland \\
\hline 81 & Wetland/Interstate toll & Buffer \\
\hline 82 & Unassociated grassy/Interstate toll & Grassland \\
\hline 83 & Unassociated woody/Interstate toll & Woodland \\
\hline 84 & Water/Interstate toll & Buffer \\
\hline 85 & Native woody/Trans-com-ut & Woodland \\
\hline 86 & Savanna/Trans-com-ut & Woodland \\
\hline 87 & Prairie/Trans-com-ut & Grassland \\
\hline 88 & Wetland/Trans-com-ut & Buffer \\
\hline 89 & Unassociated grassy/Trans-com-ut & Grassland \\
\hline 90 & Unassociated woody/Trans-com-ut & Woodland \\
\hline 91 & Water/Trans-com-ut & Buffer \\
\hline 92 & Native woody/Agriculture & Woodland \\
\hline 93 & Savanna/Agriculture & Woodland \\
\hline 94 & Prairie/Agriculture & Grassland \\
\hline 95 & Wetland/Agriculture & Buffer \\
\hline 96 & Unassociated grassy/Agriculture & Grassland \\
\hline 97 & Unassociated woody/Agriculture & Woodland \\
\hline 98 & Water/Agriculture & Buffer \\
\hline 99 & Native woody/Recreational park & Woodland \\
\hline 100 & Savanna/Recreational park & Woodland \\
\hline 101 & Prairie/Recreational park & Grassland \\
\hline 102 & Wetland/Recreational park & Buffer \\
\hline 103 & Unassociated grassy/Recreational par & Grassland \\
\hline
\end{tabular}


Appendix C. Cont'd

\begin{tabular}{|c|c|c|}
\hline $\begin{array}{c}\text { ID } \\
\text { Number }\end{array}$ & Class Names & $\begin{array}{c}\text { Habitat } \\
\text { Classification }\end{array}$ \\
\hline 104 & Unassociated woody/Recreational park & Woodland \\
\hline 105 & Water/Recreational park & Buffer \\
\hline 106 & Native woody/Conservation park & Woodland \\
\hline 107 & Savanna/Conservation park & Woodland \\
\hline 108 & Prairie/Conservation park & Grassland \\
\hline 109 & Wetland/Conservation park & Buffer \\
\hline 110 & Unassociated grassy/Conservation park & Grassland \\
\hline 111 & Unassociated woody/Conservation park & Woodland \\
\hline 112 & Water/Conservation park & Buffer \\
\hline 113 & Native woody/Vac. forst-grass & Woodland \\
\hline 114 & Savanna/Vac. forst-grass & Woodland \\
\hline 115 & Prairie/Vac. forst-grass & Grassland \\
\hline 116 & Wetland/Vac. forst-grass & Buffer \\
\hline 117 & Unassociated grassy/Vac. forst-grass & Grassland \\
\hline 118 & Unassociated woody/Vac. forst-grass & Woodland \\
\hline 119 & Water/Vac. forst-grass & Buffer \\
\hline 120 & Native woody/Wetland & Woodland \\
\hline 121 & Savanna/Wetland & Woodland \\
\hline 122 & Prairie/Wetland & Grassland \\
\hline 123 & Wetland/Wetland & Buffer \\
\hline 124 & Unassociated grassy/Wetland & Grassland \\
\hline 125 & Unassociated woody/Wetland & Woodland \\
\hline 126 & Water/Wetland & Buffer \\
\hline 127 & Native woody/Ag. wetland & Woodland \\
\hline 128 & Savanna/Ag. wetland & Woodland \\
\hline 129 & Prairie/Ag. wetland & Grassland \\
\hline 130 & Wetland/Ag. wetland & Buffer \\
\hline 131 & Unassociated grassy/Ag. wetland & Grassland \\
\hline 132 & Unassociated woody/Ag. wetland & Woodland \\
\hline 133 & Water/Ag. wetland & Buffer \\
\hline 134 & Native woody/Under devel. & Woodland \\
\hline 135 & Savanna/Under devel. & Woodland \\
\hline 136 & Prairie/Under devel. & Grassland \\
\hline 137 & Wetland/Under devel. & Buffer \\
\hline 138 & Unassociated grassy/Under devel. & Grassland \\
\hline 139 & Unassociated woody/Under devel. & Woodland \\
\hline 140 & Water/Under devel. & Buffer \\
\hline
\end{tabular}


Appendix C. Cont'd

\begin{tabular}{clc}
\hline ID & & Habitat \\
Number & Class Names & Classification \\
\hline 141 & Native woody/Abandoned & Woodland \\
142 & Savanna/Abandoned & Woodland \\
143 & Prairie/Abandoned & Grassland \\
144 & Wetland/Abandoned & Buffer \\
145 & Unassociated grassy/Abandoned & Grassland \\
146 & Unassociated woody/Abandoned & Woodland \\
147 & Water/Abandoned & Buffer \\
148 & Native woody/Water & Woodland \\
149 & Savanna/Water & Woodland \\
150 & Prairie/Water & Grassland \\
151 & Wetland/Water & Buffer \\
152 & Unassociated grassy/Water & Grassland \\
153 & Unassociated woody/Water & Woodland \\
154 & Water/Water & Buffer \\
155 & Native woody/unclassified & Woodland \\
156 & Savanna/Unclassified & Woodland \\
157 & Prairie/Unclassified & Grassland \\
158 & Wetland/Unclassified & Buffer \\
159 & Unassociated grassy/Unclassified & Grassland \\
160 & Unassociated woody/Unclassified & Woodland \\
161 & Water/Unclassified & Buffer \\
162 & Urban land & Urbanland \\
163 & Urban grass & Urbangrass \\
164 & Agriculture & Agriculture
\end{tabular}

